\title{
Influence of Prescribed Burning on Upland Soil Properties in Mark Twain National Forest, Southeast Missouri Ozarks
}

\author{
Megan Lynn Hente \\ Missouri State University, Hente4@live.missouristate.edu
}

As with any intellectual project, the content and views expressed in this thesis may be considered objectionable by some readers. However, this student-scholar's work has been judged to have academic value by the student's thesis committee members trained in the discipline. The content and views expressed in this thesis are those of the student-scholar and are not endorsed by Missouri State University, its Graduate College, or its employees.

\section{Follow this and additional works at: https://bearworks.missouristate.edu/theses}

Part of the Forest Management Commons, Other Environmental Sciences Commons, Other Forestry and Forest Sciences Commons, and the Soil Science Commons

\section{Recommended Citation}

Hente, Megan Lynn, "Influence of Prescribed Burning on Upland Soil Properties in Mark Twain National Forest, Southeast Missouri Ozarks" (2017). MSU Graduate Theses. 3066.

https://bearworks.missouristate.edu/theses/3066

This article or document was made available through BearWorks, the institutional repository of Missouri State University. The work contained in it may be protected by copyright and require permission of the copyright holder for reuse or redistribution.

For more information, please contact BearWorks@library.missouristate.edu. 
INFLUENCE OF PRESCRIBED BURNING ON UPLAND SOIL PROPERTIES

IN MARK TWAIN NATIONAL FOREST, SOUTHEAST MISSOURI OZARKS

\author{
A Masters Thesis \\ Presented to \\ The Graduate College of \\ Missouri State University \\ In Partial Fulfillment \\ Of the Requirements for the Degree \\ Master of Science, Geospatial Science in Geography, Geology and Planning \\ By \\ Megan Hente \\ May 2017
}


Copyright 2017 by Megan Lynn Hente 


\title{
INFLUENCE OF PRESCRIBED BURNING ON UPLAND SOIL PROPERTIES
}

\section{IN MARK TWAIN NATIONAL FOREST, SOUTHEAST MISSOURI OZARKS}

Geography, Geology, and Planning

Missouri State University, May 2017

Master of Science

Megan Hente

\begin{abstract}
In the Mark Twain National forest there is a collaborative effort to restore parts of the forest to its original shortleaf pine-oak woodland areas by using a combination of silviculture and prescribed fire. The purpose of this project is to assess the effects of prescribed burning on upland forest and soil physical properties that influence erosion processes across a gradient of burned sites of different ages and unburned sites. A combination of geospatial, field, laboratory, statistical (one-way ANOVA) and modeling (USLE) methods were used to assess the effects of prescribed burns on forest and soil characteristics in Big Barren Creek watershed. On average, burned sites had significantly lower leaf litter depth (10-30\%) and duff depth (10-40\%), higher organic matter content $(15-20 \%)$ and lower bulk densities $(8-12 \%)$ in the first $0-5 \mathrm{~cm}$ of the soil than unburned sites. Prescribed burns did not significantly effect soil texture at any depth or percent organic matter and bulk density below $5 \mathrm{~cm}$. Basal area, coarse woody debris and seedling/sapling densities were not significantly different among burned and unburned sites. There are no significant differences for soil and forest characteristics among unburned stand types, except litter and duff depth, which is stand dependent (pine> mixed $>$ oak). USLE results indicate burned sites may have similar annual soil erosion rates compared to unburned sites.
\end{abstract}

KEYWORDS: prescribed fire, forest fires, forest management, Ozarks, soils, soil health This abstract is approved as to form and content

Robert Pavlowsky, $\mathrm{PhD}$ Chairperson, Advisory Committee Missouri State University 
INFLUENCE OF PRESCRIBED BURNING ON UPLAND SOIL PROPERTIES

IN MARK TWAIN NATIONAL FOREST, SOUTHEAST MISSOURI OZARKS

\author{
By \\ Megan Hente

\begin{abstract}
A Masters Thesis
Submitted to the Graduate College

Of Missouri State University

In Partial Fulfillment of the Requirements

For the Degree of Master of Science, Geospatial Science in Geography, Geology and Planning
\end{abstract}

May 2017

Approved:

Robert Pavlowsky, $\mathrm{PhD}$

Xiaomin Qiu, PhD

Xin Miao, $\mathrm{PhD}$

Thomas DeWitt, MS

Julie Masterson, PhD: Dean, Graduate College 


\section{ACKNOWLEDGEMENTS}

There are many people I would like to thank for their support and guidance over the last two years. First, I would like to thank my advisor Dr. Robert Pavlowsky for this incredible opportunity to work as a research assistant with OEWRI and with the United States Forest Service. Thank you for your support and guidance through this project. Second, I want to say thank you to Dr. Ana Londoño for her constant support and guidance in academics and in life. A huge thank you to Marc Owen for sharing so much of his time guiding me through the woes of GIS, and assisting me with lab analyses and technical data. I would like to thank my committee members Tom DeWitt and Drs. Xin Miao and Xiaomin Qiu for their support and guidance in executing this project. A special thanks to Josh Voss, Nick Bradley, Kayla Geier, Rachael Bradley, Matthew Thies, Holly Duff, Ashlee Huerta, Ashton Jones, Emma Gibson, Caitlin Canfield, Jameelah Rodriguez and Kelly Rose who helped make sampling and field data collection possible.

I would like to thank the United States Forest Service for funding this thesis project through the "Watershed Monitoring Study" under agreement number 15-CS11090500-36. I would also like to thank the Ozark Environmental and Water Resources Institute, the Graduate College at Missouri State University, the Department of Geography, Geology and Planning, and the College of Natural and Applied Sciences for their funding for supplies, field work and travel to and from conferences.

A huge thank you to my friends for their support, and enthusiasm. Last but not least, thank you Mom and Dad for your never-ending encouragement, words of wisdom and love. I wouldn't be who I am or where I am without you. 


\section{TABLE OF CONTENTS}

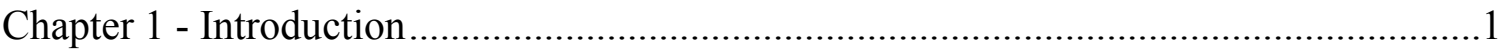

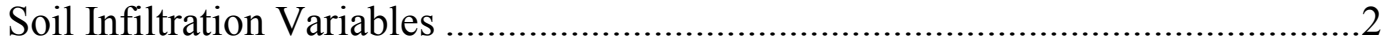

Infiltration and Runoff ...............................................................................

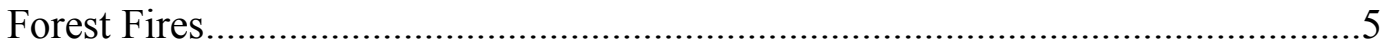

Fire Impacts on Runoff and Stream Flow ............................................................

Prescribed Fire Management in Mark Twain National Forest................................... 9

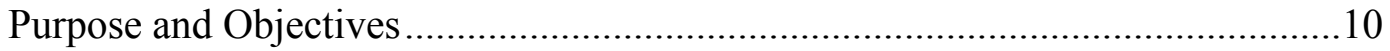

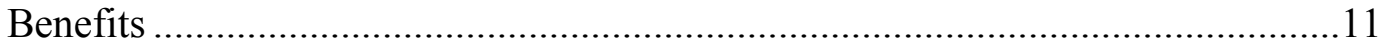

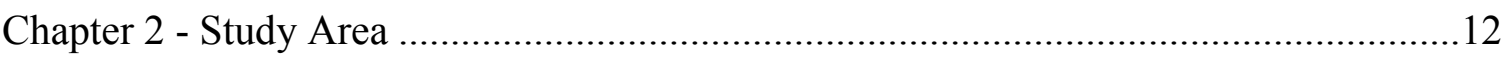

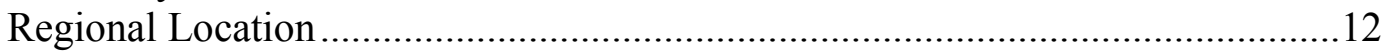

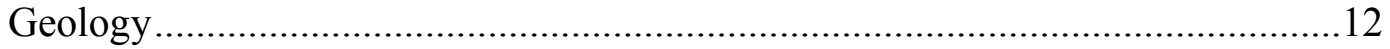

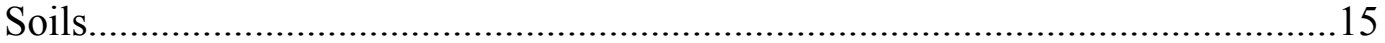

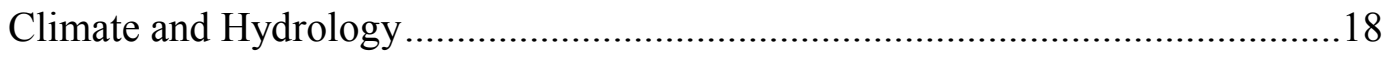

Land Use and Vegetation..............................................................................19

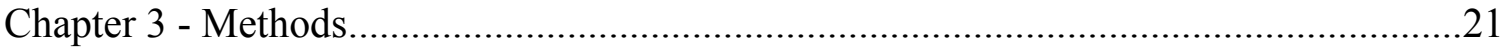

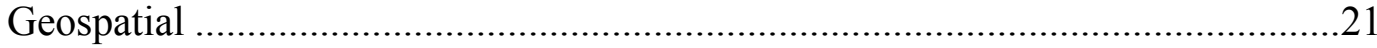

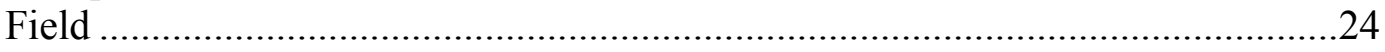

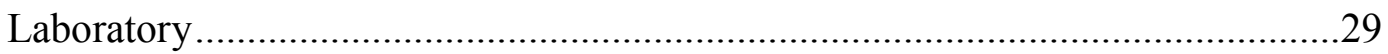

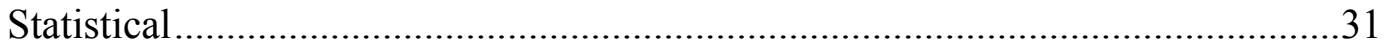

Universal Soil Loss Equation.......................................................................32

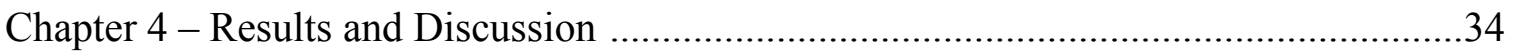

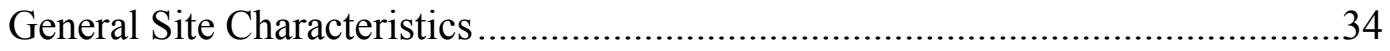

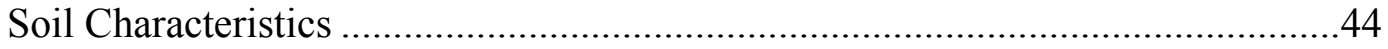

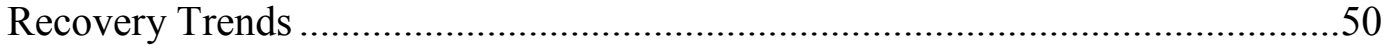

Universal Soil Loss Equation........................................................................54

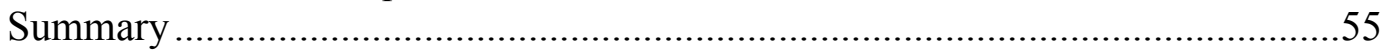

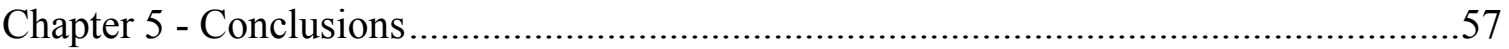

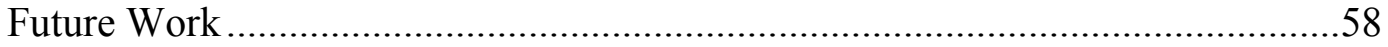

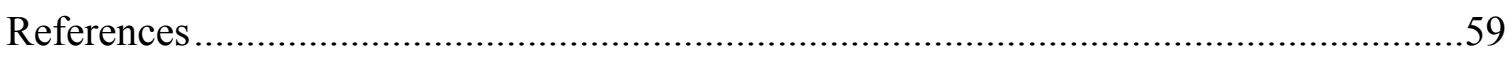

Appendices ....................................................................................................67

Appendix A. Methods, Definitions, and Units Measured for Variables.................67

Appendix B. Site Descriptions, Characteristics and Management History ............69

Appendix C. Photo Log ..................................................................................72

Appendix D. Site Locations, Witness Trees and Tree Type..................................79

Appendix E. Subplot Vegetation Form.............................................................83

Appendix F. Field Method Error, Relative Percent Difference ...............................85 
Appendix G. Dry Mass of Litter and Duff......................................................86

Appendix H. Nomograph to Determine Soil Erodibility (K-factor) .....................88

Appendix I. Soil Texture $<2 \mathrm{~mm}$ and Percent Rock Fragments $>2 \mathrm{~mm}$ 


\section{LIST OF TABLES}

Table 1. Reported soil physical properties from the Web Soil Survey

Table 2. Reported soil texture for $0-5 \mathrm{~cm}$ of the soil profile from the Web Soil Survey ..17

Table 3. Reported soil texture for $5-10 \mathrm{~cm}$ of the soil profile from the Web Soil Survey

Table 4. Reported soil texture for 20-30 cm of the soil profile from the Web Soil

Survey .18

Table 5. Oak and other hardwood stand characteristics. .35

Table 6. Pine stand characteristics .36

Table 7. Mixed stand characteristics

Table 8. Significant values in bold as determined by one-way ANOVA; burned versus unburned (Mean $\pm \mathrm{SD})$.

Table 9. Significant values in bold as determined by one-way ANOVA; burned and unburned differences among stand types (Mean \pm SD)

Table 10. Universal Soil Loss Equation factors .55 


\section{LIST OF FIGURES}

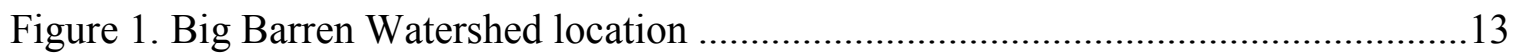

Figure 2. Geology of the Big Barren Watershed ..............................................................14

Figure 3. Most common upland soils (0-8\%) in the Big Barren Watershed.......................16

Figure 4. Map of the Big Barren Watershed with burn units and sampling sites ..............23

Figure 5. USFS Forest Inventory and Analysis subplot sampling layout.........................25

Figure 6. Site visits and accomplishments flowchart.....................................................28

Figure 7. Basal area among stand types and time sampled...........................................40

Figure 8. Coarse woody debris by stand type and time sampled......................................41

Figure 9. Seedling density by stand type and time sampled ..........................................43

Figure 10. Sapling density by stand type and time sampled...........................................43

Figure 11. Litter depth by stand type and time sampled................................................45

Figure 12. Duff depth by stand type and time sampled ................................................46

Figure 13. Percent organic matter by stand type and time sampled ..................................48

Figure 14. Bulk density by stand type and time sampled ...............................................49

Figure 15. Mean particle diameter by stand type and time sampled ..............................50

Figure 16. Litter depth measurements for date measured and last year burned ................51

Figure 17. Duff depth measurements for date measured and last year burned..................52

Figure 18. Percent organic matter depth measurements for date measured and last year

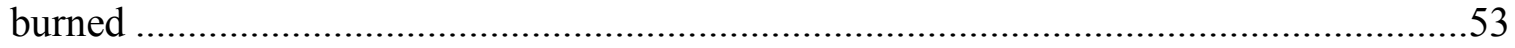

Figure 19. Bulk density measurements for date measured and last year burned...............54 


\section{CHAPTER 1 - INTRODUCTION}

Fires are major features of forest disturbances that play an important role in the management and maintenance of forest ecosystems. Prescribed burning is a forest management practice that is used to reduce understory growth, eradicate invasive species and create clear-open stands (Hamman et al., 2008; Wade and Lundsford, 1990).

Prescribed fires are used by the United States Forest Service and land managers throughout North American prairie and forest ecosystems (Gray et al., 2013). These fires are used to meet objectives which include social, cultural, ecological, and economic benefits (Gray et al., 2013). Objectives often include stand structure improvement, habitat restoration, enhancing biodiversity, and reducing the risk of wildfires, pathogens and pests (Gray et al., 2013).

Prescribed burning effects forests at the vegetation and soil interface, which can have a direct effect on the hydrologic processes effecting local streams and rivers (Elliot and Vose, 2006). Prescribed fires can reduce understory vegetation and ground cover such as the litter and duff layers (Elliot and Vose, 2006; Gurbir et al., 2017; Zabowski et al., 2007). Forest characteristics that control hydrologic processes include vegetation cover, leaf litter, organic matter (OM), and bulk density (BD). These characteristics effect soil infiltration which affects runoff and erosion and has a direct effect on watershed quality. 


\section{Soil Infiltration Variables}

Vegetation Cover. Vegetation cover is important in protecting soils from raindrop impact and subsequent erosion. Soils are protected by vegetation through interception, restraint, retardation, infiltration, and transpiration (White et al., 2006). Interception absorbs rainfall energy and prevents soil compaction. Vegetation roots restrain soil particles and maintains soil structure through porosity and permeability, increasing infiltration (White et al., 2006). Retardation increases surface roughness through plant residues, which slows the rate of runoff. Transpiration prevents the soil from being oversaturated and helps to slow soil runoff (Gray and Leiser 1982; Gurbir et al., 2017). Loch (2000) found that erosion was greatly reduced with variable vegetation cover while simulating a 100 year flood over uniform slopes. Erosion was reduced from 30-35 tons per hectare $(\mathrm{t} / \mathrm{ha})$ at $0 \%$ vegetation cover to $0.5 \mathrm{t} / \mathrm{ha}$ at $47 \%$ vegetation cover (Loch, 2000). Vegetation cover variables commonly measured include trees, seedlings and saplings, shrubs, and herbaceous flora (Appendix A) (FIA, 2014).

Ground Cover. Ground cover is a function of forest canopy and vegetation cover and acts as a secondary barrier of protection to prevent soil erosion. Coarse woody debris (CWD), litter and duff are important ground cover components that are located above the soil A-horizon. Coarse woody debris consists of fallen dead trees and branches just above the litter and duff layers. Litter is the layer of freshly fallen leaves, needles, twigs and loose plant material that can still be easily identified (FIA, 2014). Duff is the mat-like layer below litter and above the soil A-horizon that consists of decomposed litter components, which are not easily identified (FIA, 2014; Ottmar and Andreu, 2007). Coarse woody debris measurements are made using a measuring tape to measure the 
diameter and length (FIA, 2014; Woodall and Monleon, 2008). Litter and duff measurements are made using a ruler and a sampling frame of known area (Appendix A) (FIA, 2011). Coarse woody debris, litter and duff protect soils from raindrop impact, and prevents the soil from crusting or sealing pore space, all of which reduce infiltration rates (Covert et al., 2005; Li et al., 2014). Litter and duff thickness provide more time for soil infiltration, and decrease rates of soil erosion by increasing surface roughness ( $\mathrm{Li}$ et al., 2014). Vegetation cover and ground cover play an important role in protecting soils, increasing soil $\mathrm{OM}$, reducing $\mathrm{BD}$ and increasing infiltration rates.

Soil Physical Properties. Soil physical properties such as OM and BD are important indicators of soil health. Organic matter is made up of several components including leaf litter, duff and the soil mineral A-horizon (Appendix A) (DeBano, 1991). Organic matter stores a large portion of terrestrial carbon (C) and helps protect soils from wind and water erosion by making the structure of the soil more stable, which increases infiltration rates (Chaudhari et al., 2013; Schoenholtz et al., 2000). Soil OM is a critical pool in the $\mathrm{C}$ cycle and holds 10 to 1,000 times more water and nutrients than equal amounts of soil minerals. Forest ecosystems contain more than half of all terrestrial $\mathrm{C}$ and about $70 \%$ is stored in soils (Jandl et al., 2004; Nave et al., 2010). Forests are an important $\mathrm{C}$ sink that mitigates rising atmospheric carbon dioxide and climate change (Nave et al. 2010). Additionally, OM is a major source of nutrients for plants such as C, Nitrogen (N) and Phosphorus (P) (Davis, 2006; Schoenholtz et al., 2000; USDA-NRCS, 2015).

Bulk density is defined as the dry weight of soil less than $2 \mathrm{~mm}$ in size per unit volume of soil (USDA Kellogg Soil Survey, 2014). Bulk density is an indicator of soil 
compaction (Appendix A) (USDA-NRCS, 2008). The effects of rock material greater than $2 \mathrm{~mm}$ in diameter are removed from BD calculations (USDA-NRCS, 2004). Soil compaction occurs when stress is applied to soil causing pore spaces to shrink or collapse (Hamza and Anderson, 2005). Soil compaction leaves soils vulnerable to erosion. Infiltration rates are typically inversely related to BD. Lower BD has less compaction, more pore spaces and higher infiltration rates, whereas higher $\mathrm{BD}$ is indicative of compacted soils with lower infiltration rates (USDA-NRCS, 2008). Soil bulk densities vary naturally among soils of different textures, structures and OM content (Chaudhari et al., 2013). Soil texture or particle size distribution is important because it influences erosion processes (McLaren and Bowles, 1985). Bulk density is also affected by anthropogenic influences that remove vegetation cover and cause soil compaction. Soil erosion resulting from lack of ground cover fills pore space, reduces porosity, and increases BD (USDA-NRCS, 2008). Therefore, high BD can restrict root growth and movement of air and water through the soil (USDA-NRCS, 2008). Vegetation cover, ground cover, $\mathrm{OM}$ and $\mathrm{BD}$ play an important role in hydrologic processes such as infiltration and runoff.

\section{Infiltration and Runoff}

Reduced infiltration and increased runoff can lead to surface erosion and runoff processes such as rain drop impact, sheet, rill and gully erosion (Menashe, 1998). Accelerated rates of erosion and runoff cause negative watershed effects by degrading water quality and forest productivity (Menashe, 1998). Runoff increases sediment and nutrient loads, which harm aquatic life (Menashe, 1998). Suspended sediment loads 
degrade habitat quality for fish and invertebrates by filling pore space in gravel beds where certain species of fish spawn, and by altering stream geomorphology (Henely et al., 2000). Nutrient loading causes eutrophic waters which increases algal blooms and turbidity, creating hypoxic conditions for aquatic species (Follet, 1995). Forest soils are subject to increased runoff and leaching through disturbances such as fire.

\section{Forest Fires}

Forest fires can occur naturally or can be used as a management tool to promote forest restoration and eradication of invasive species. Forest fires can alter forest structure and affect soil physical, chemical, mineralogical and biological properties (Certini, 2005). Fires can reduce forest fuels and organic soil nutrient pool sizes, increase soil nutrient turnover rates, and redistribute nutrients through the soil profile (Fisher and Binkley, 2000). The reduction of fuel loads can reduce the risk of wild fires. Fuel loads consist of dry/dead vegetation, CWD, leaf litter, duff and OM, which are all highly variable by location (Graham et al., 2004; Sikkink et al., 2009). When fuel loads are reduced, soil OM which holds important nutrients such as $\mathrm{C}, \mathrm{N}$ and $\mathrm{P}$, is also reduced. A decrease in nutrient pool sizes can reduce soil productivity and therefore forest health (Nave et al., 2010). Alternatively, fires can improve soil health by increasing nutrient turnover rates, which help redistribute nutrients through the soil profile, making them available to plants (Certini, 2005). The effects of forest fires on soil properties depends on the type of fire.

There are two types of forest fires: wild and prescribed. The extent of the effects caused by these types of fire depends on fire severity. Fire severity depends on the intensity and duration of a fire (Elliot and Vose, 2006). Neary et al. (2005) define fire 
intensity as the rate at which thermal energy is produced and duration as how long the burn occurs at a particular point and time. Fire severity is influenced by the amount of fuel available (Graham et al., 2004). Understanding fire severity can help scientists determine how fires affect soil characteristics and can aid in implementing appropriate management practices that aim to promote or maintain forest and soil health (Gurbir et al., 2017).

Wildfires tend to range from moderate to high severity. Wildfires can completely alter forest structure, deplete vegetation, leaf litter, OM and over story canopies, leaving the soils vulnerable to wind and water erosion (Elliot and Vose, 2006). These fires can alter forest structure by completely killing trees and understory vegetation, making forests more susceptible to invasive species (Bendix and Cowell, 2010). Alternatively, forest structure can influence the severity of a burn by the amount and type of fuels available (Bendix and Cowell, 2010). Wildfires effect soil conditions by completely consuming vegetation cover, leaf litter and OM, which creates soil hydrophobic conditions and subsequently increases BD (Elliot and Vose, 2006). Wildfires often have long-term negative effects on forest structure, soil and water quality.

Prescribed fires are controlled burns which tend to be low to moderate in burn severity (Gurbir et al., 2017). Low severity burns tend to only consume surface fuels such as leaf litter, leaving the duff and underlying soil horizons protected with partially charred organic material (Elliot and Vose, 2006; Gurbir et al., 2017). Prescribed burning is often used to help produce forest structures and fuel characteristics that reduce the likelihood of wildfires which cause dramatic changes in biophysical conditions (Graham et al., 2004). Prescribed burns are often used to promote the restoration of dominant 
vegetation through eradication of invasive species and to return forests with shadetolerant shrubs to their original clear-open stands (Certini, 2005; Gurbir et al., 2017;

Tiedemann et al., 1998). Unlike wildfires, prescribed fires have fewer negative effects on forest and soil characteristics and can improve soil productivity and infiltration. However, there are concerns about the effects of prescribed fire on forest conditions that effect water quality.

\section{Fire Impacts on Runoff and Stream Flow}

Prescribed fires affect vegetation, leaf litter, duff, OM, and BD. These effects can be positive rather than negative. Vegetation cover and litter are the main influences of sediment responses to fire (Elliot and Vose, 2006). Increases in runoff negatively affect water quality by increasing suspended sediment and nutrient loads. Excess sediment loads are the main pollutant of streams in managed forests (Phillips et al., 2000) and the primary threat to the quality and sustainability of aquatic habitats (Henely et al., 2000). Other threats to water quality from runoff include the potential for increased concentrations of $\mathrm{P}$ and $\mathrm{N}$ in nearby streams, leading to eutrophication and hypoxic conditions which kill aquatic species, and limit aquatic vegetation growth (Davis, 2006).

Elliot and Vose (2006) found that sediment yields from prescribed fires were smaller than those exposed to wildfires, because prescribed fires were not consuming the entire forest floor or destroying forest canopies. Gurbir et al (2017), also found no significant increase in soil erosion or sediment loss from prescribed fire in a mixed hardwood forest of southern Illinois. Slight increases in erosional processes following a prescribed fire can be mitigated depending on how soon surface cover is able to be re- 
established (Gurbir et al., 2017). For this reason, prescribed burns are often implemented in early winter and spring months (Gurbir et al., 2017; USDA-FS, 2012). Prescribed burns can facilitate the growth of herbaceous flora and can increase plant available nutrients, which is important for soil and forest health, as well as maintaining vegetative cover (Elliot and Vose, 2006). Unlike controlled burns, wildfires often completely destroy forest vegetation cover and ground cover resulting in increased rates of runoff and erosion (Elliot and Vose, 2006).

Prescribed fires can improve the soil health over time by increasing soil productivity (Carter and Foster, 2003). Prescribed fires have been found to increase soil OM (Patterson et al., 2004; Zabowski et al., 2007). Chaudhari et al. (2013), found that as OM increased, BD decreased. Prescribed fires indirectly effect BD. Massman and Frank (2006) measured soil bulk densities from two sites burned in different years. They sampled 3.5 years after a burn at the first site and 1.5 years after a burn at the second site. They found that fire itself did not directly cause any significant changes in BD. Additionally, Massman and Frank suspect that forest sites which are managed by both logging and burning may have increased bulk densities because of compaction caused by logging vehicles (Massman and Frank, 2006). While prescribed fires are not found to negatively effect $\mathrm{OM}$ and $\mathrm{BD}$, wildfires can completely consume duff, $\mathrm{OM}$, and increase $\mathrm{BD}$ and the water repellency of soils, which further increases the risk for runoff and erosion (Elliot and Vose, 2006).

Prescribed fires can be used to facilitate and maintain healthy forest growth. Wildfires tend to have long lasting negative effects on the environment. In general, prescribed fires effects on soil and erosion are considerably less significant than wildfire 
effects. Prescribed fires usually have less severe consequences than wildfires and are often a positive influence on vegetation and soil properties which influence runoff and erosion (Reardon et al., 2005, Elliot and Vose, 2006).

\section{Prescribed Fire Management in Mark Twain National Forest}

The Eleven Point Ranger District of Mark Twain National Forest is located in Southeast Missouri. The forest expands across parts of Shannon, Carter, Oregon and Ripley counties. In 2006, the Eleven Point Ranger District was identified as an Ozark landscape with significant pine-oak woodland restoration potential (Nigh, 2007). In 2012 the Collaborative Forest Landscape Restoration Project (CFLRP) was implemented to restore the forest to its original shortleaf pine-oak stands (USDA-FS, 2012).

The CFLRP manages stands with a combination of prescribed burning in spring months and silviculture. Silviculture involves thinning, harvesting, pruning, site preparation and prescribed burning (USFS-FSM, 2014). Shortelaf pines are shade intolerant and require semi-open canopy cover and ground cover (Gwaze et al., 2007). Prescribed burning along with silviculture removes understory vegetation, creates clearopen stands and helps eradicate invasive species, which creates favorable conditions for shortleaf pine regeneration (Certini, 2005; Gwaze et al., 2007; Tiedemann et al., 1998). The Eleven Point Ranger District is not just home to the National Forest, but is home to local farmers and other residents.

In Missouri 85\% of forested land is privately owned (Reitz and Gwaze, 2010). Surveys suggest that the majority of residents, landowners, recreationists, and tourists approve of prescribed fire, especially when they are well informed about the methods and 
benefits (McCaffrey, 2006; Reitz and Gwaze, 2010; Winter et al., 2005). However, residents and local agencies within or near the Eleven Point Ranger District of Mark Twain National Forest question the effects of prescribed burning on water quality. The Eleven Point Ranger District is part of the Current river watershed, which is part of the Ozark National Scenic Riverways (OZAR). The OZAR was the first national park to protect river systems (Vana-Miller, 2007). There is little known about how prescribed burning is effecting vegetation, soil and water quality in the Eleven Point Ranger District of Mark Twain National Forest.

\section{Purpose and Objectives}

The purpose of this project is to assess if and how prescribed burning is affecting forest soil qualities that play an important role in forest hydrology, and may subsequently affect water quality in Mark Twain National Forest. Studies that have been conducted in the Missouri Ozarks have assessed prescribed fire effects on forest structure, composition and shortleaf pine regeneration (Blake and Schuette, 2000; Blizzard et al., 2007; Gwaze et al., 2007; Knapp et al., 2015). Gurbir et al (2017) studied the effects of prescribed burning on erosion potential in southern Illinois Ozarks. This study assessed leaf litter cover and measured suspended sediment loads. It is one of the only studies to assess soil erosion occurring after a prescribed burn. There are few, if any, studies that quantify the effects of prescribed burning on forest soil physical conditions in the Missouri Ozarks.

This project will help future scientists and land managers understand how forest management practices, such as prescribed fire, effect soil physical properties in the Ozarks of southeast Missouri. It is important to identify unburned soil characteristics in 
Mark Twain National Forest to assess how prescribed burning may be affecting characteristics such as CWD, litter, duff, OM, BD and texture. To accomplish this, the following objectives have been identified:

1) Implement a monitoring network to determine baseline conditions for unburned forest sites for which compare burned sites of varying frequency;

2) Assess spatial soil and vegetation cover differences between burned and unburned sites by stand types and using statistical tests;

3) Evaluate temporal trends in burn effects and soil recovery on selected sites; and

4) Discuss the implications of these findings on runoff and soil erosion rates.

\section{Benefits}

The information gathered from this study can benefit both scientific research and regional land management. There is a gap in knowledge in examining prescribed fire effects on soil physical properties and subsequent erosion in the Missouri Ozarks. Most studies conducted focus on prescribed fire effectiveness for shortleaf pine restoration. Vegetation cover and soil physical properties such as $\mathrm{OM}$ and $\mathrm{BD}$ are important factors influencing runoff and erosion. This study provides valuable insight into how prescribed fires effect vegetation cover and soil physical properties which influence runoff and erosion. This research will help clarify concerns surrounding prescribed fires effects on erosion and subsequent water quality. By understanding how prescribed fires effect vegetation cover and soil physical properties, this study gives land managers a better understanding of the effects of prescribed burning and aid land managers in making appropriate decisions to further prevent erosion and protect water quality. 


\section{CHAPTER 2 - STUDY AREA}

\section{Regional Location}

The Big Barren Watershed is located in the Eleven-Point Ranger District of Mark Twain National Forest in southeast Missouri. It is a sub watershed of the Current River basin (Figure 1). The watershed $\left(191 \mathrm{~km}^{2}\right)$ drains into the Current River located between Van Buren and Doniphan, Missouri with local relief ranging from 30 to $60 \mathrm{~m}$ (MDNR 1986).

\section{Geology}

The geology of the Eleven-point area consists of Upper Cambrian and Lower Ordovician dolomite, sandstone, limestone, shale and chert, which overlie Middle Proterozoic rhyolite and granite (Ornoff et al., 2001). Dolomite is the dominant rock type with only the Potosi Dolomite and younger units of the Upper Cambrian and Lower Ordovician exposed (Ornoff et al., 2001). Three major formations located in the ElevenPoint area of Mark Twain National Forest are the Roubidoux Formation, Gasconade Formation and the Eminence Formation (Kabrick et al., 2000). The Roubidoux Formation is limited to the highest summits and ridges of the Eleven-Point area, while the Gasconade Formation makes up most of the secondary ridges and backslopes (Kabrick et al., 2000). Within the Big Barren watershed, the most common formation is the Roubidoux formation followed by the Gasconade dolomite and Jefferson City dolomite (Figure 2). 


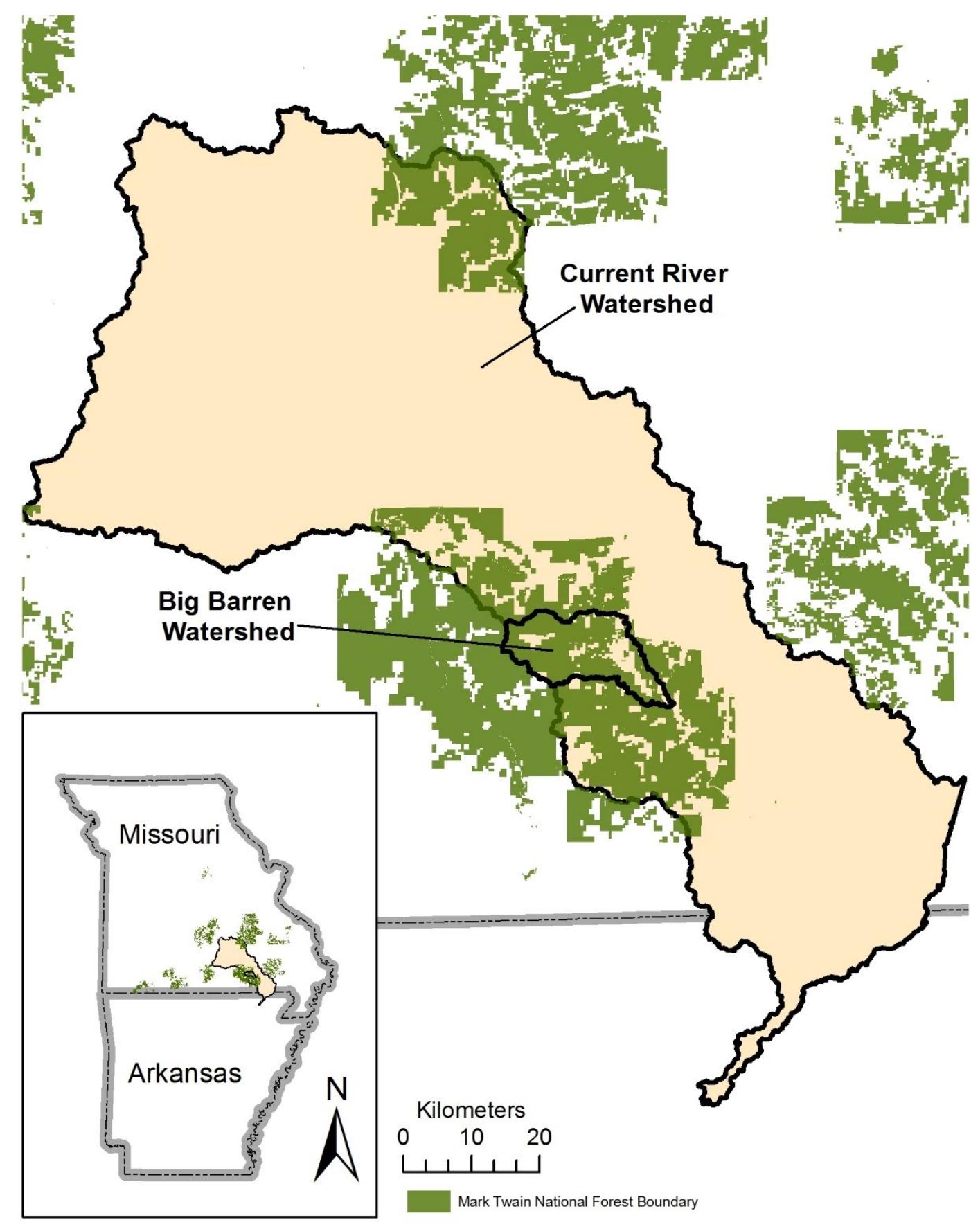

Figure 1. Big Barren Watershed location. 


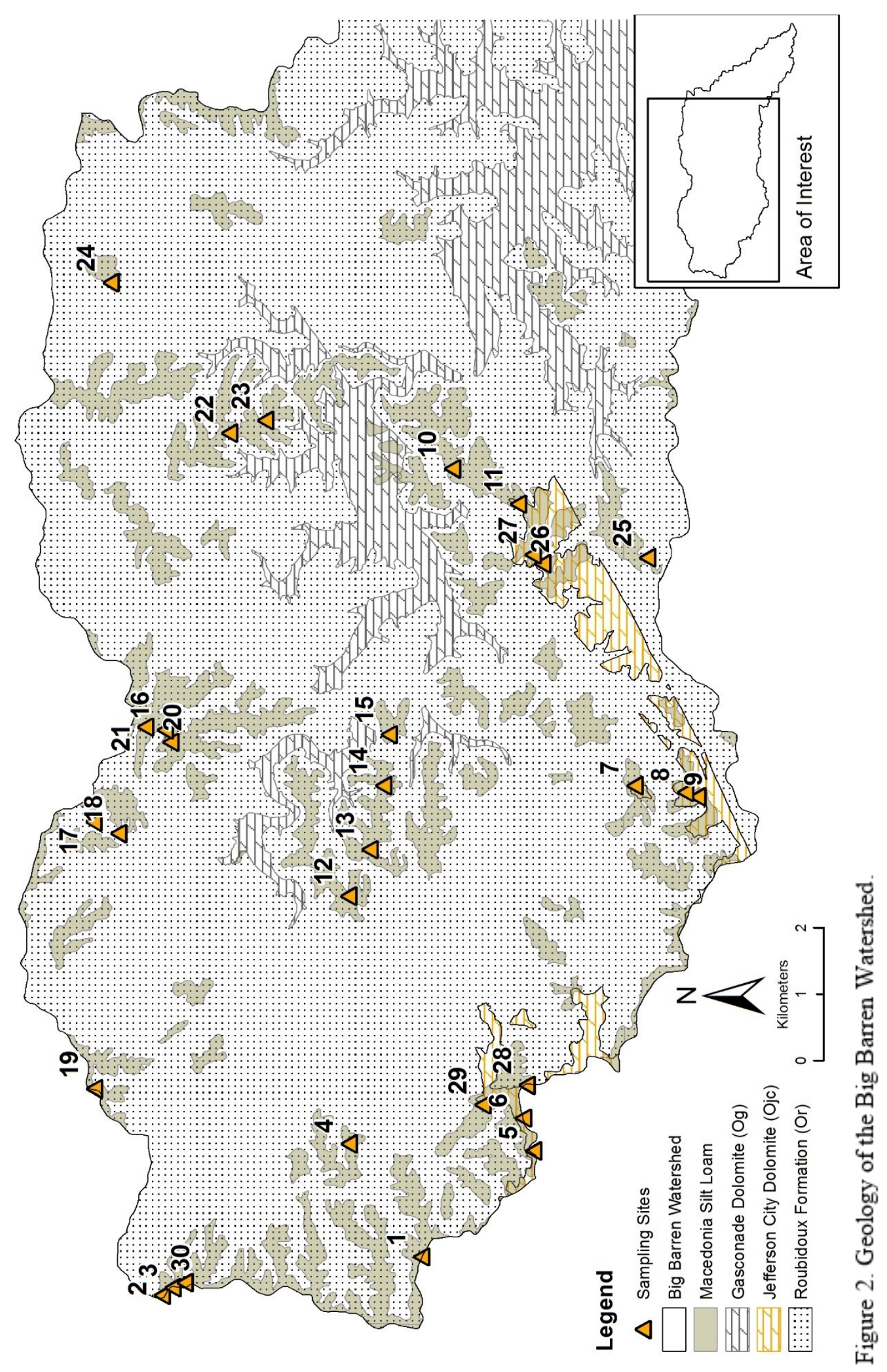




\section{Soils}

Soils within the Eleven-Point region vary considerably due to the varying geologic strata and geomorphology within the Mark Twain National Forest. Soils related to the Roubidoux and Upper Gasconade hillslope sediments and residuum are characteristic of very deep loamy-skeletal soils with low base saturations. Broad-flat ridges are often part of the Roubidoux and Upper Gasconade Formations and are mantled by Quaternary loess deposits (Kabrick et al., 2000). The most common upland soil series are as follows: Macedonia silt loam, Captina silt loam, Clarksville very gravelly silt loam, Coulstone gravelly sandy loam, Doniphan gravelly silt loam, Wilderness gravelly silt loam, Poynor very gravelly silt loam, and Viraton silt loam and (Figure 3). General soil physical properties reported from the Web Soil Survey are in Tables 1-4 (USDA-WSS, 2017).

For this study, the Macedonia soil series was selected for sampling areas to examine fire effects on soils. The Macedonia soil series is one of the most common upland soils with the least amount of rock fragments (USDA-NCSS, 2005). Macedonia soil series are located on summits or ridgetops. Macedonia soils are in the Ultisols soil order of classification and are associated with the Roubidoux and the Upper Gasconade formations (Meinert et al., 1997). They are typically very deep and well drained and formed in a small layer of loess or silty slope alluvium as well as underlying residuum from clayey shales and cherty dolomite or limestone (USDA-NCSS, 2005). Slopes for these soils range from 2-15 percent (USDA-NCSS, 2005). 


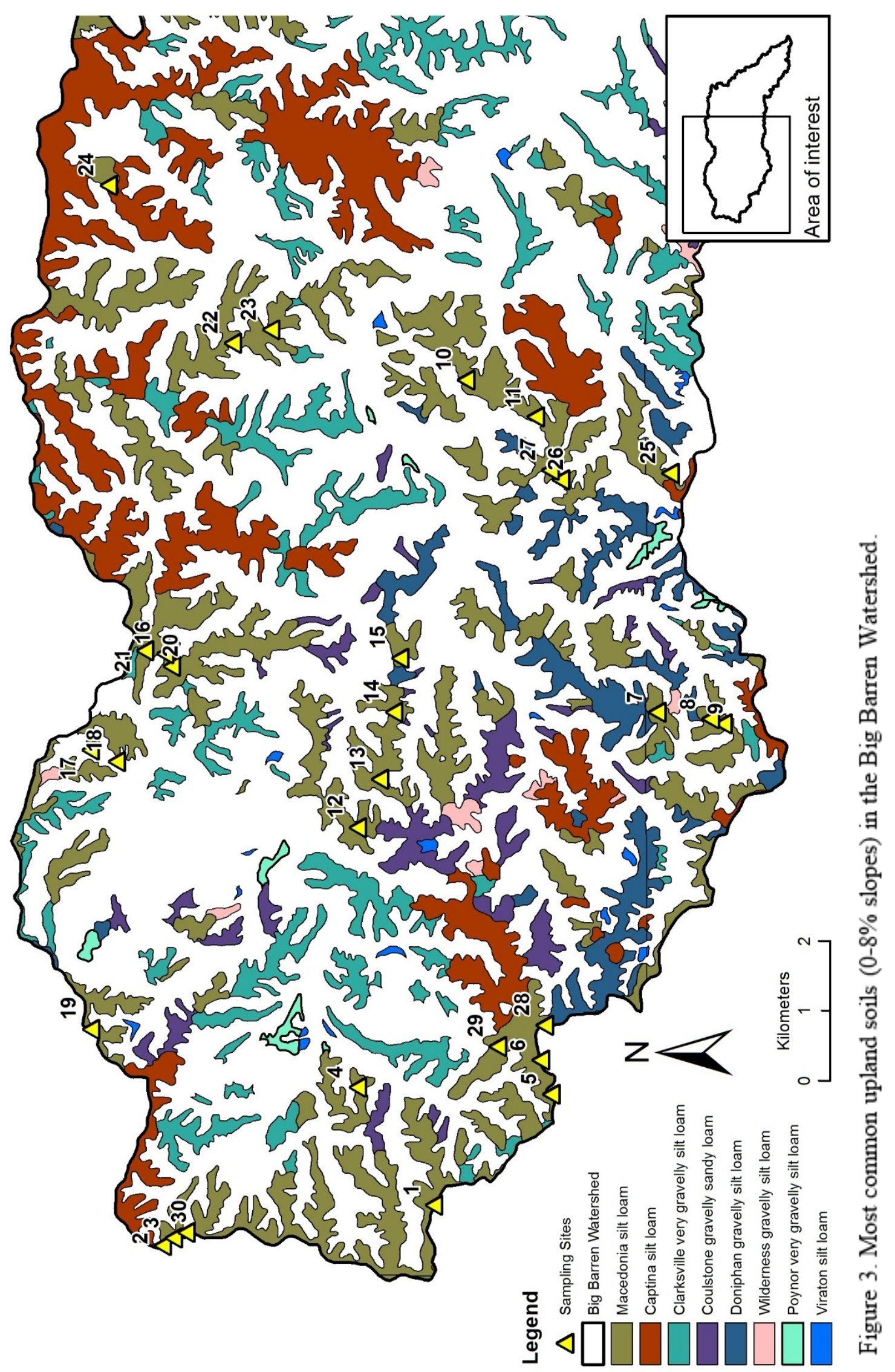


Table 1. Reported soil physical properties (USDA-WSS, 2017).

\begin{tabular}{cccccc}
\hline Soil Series & $\begin{array}{c}\text { BD 0-5 cm } \\
1 / 3 \mathrm{bar}\end{array}$ & $\begin{array}{c}\text { BD 5-10 cm } \\
1 / 3 \mathrm{bar}\end{array}$ & $\begin{array}{c}\text { \% OM 0-5 } \\
\mathrm{cm}\end{array}$ & \% OM 5-10 cm & $\begin{array}{c}\text { \% OM 20-30 cm } \\
\text { subsoil }\end{array}$ \\
\hline Macedonia & 0.87 & 1.38 & 21.98 & 3.3 & 0.77 \\
Clarksville & 0.76 & 1.2 & 22.16 & 3.6 & 1.2 \\
Coulstone & 0.95 & 1.51 & 30.3 & 4.5 & 1.2 \\
Captina & 1.3 & 1.3 & 4.5 & 4.5 & 0.4 \\
Doniphan & 1.33 & 1.33 & 4.47 & 4.47 & 2.24 \\
Poynor & 1.33 & 1.33 & 0.75 & 0.75 & 0.5 \\
Wilderness & 1.46 & 1.46 & 3.3 & 3.3 & 1.14 \\
Viraton & 1.47 & 1.47 & 1.6 & 1.6 & 0.7 \\
\hline
\end{tabular}

Table 2. Reported soil texture for $0-5 \mathrm{~cm}$ of the soil profile (USDA-WSS, 2017).

\begin{tabular}{cccc}
\hline Soil Series & \% Sand & $\begin{array}{c}\text { \% Silt } \\
0-5 \mathrm{~cm}\end{array}$ & \% Clay \\
\hline Macedonia & 26.2 & 65.5 & 8.3 \\
Clarksville & 21.2 & 67.5 & 11.3 \\
Coulstone & 53.5 & 39.4 & 7.1 \\
Captina & 14.4 & 76.1 & 9.5 \\
Doniphan & 31.6 & 52 & 16.4 \\
Poynor & 22 & 66 & 12 \\
Wilderness & 16.1 & 75.7 & 8.2 \\
Viraton & 17 & 70 & 13 \\
\hline
\end{tabular}


Table 3. Reported soil texture for $5-10 \mathrm{~cm}$ of the soil profile (USDA-WSS, 2017).

\begin{tabular}{cccc}
\hline Soil Series & \% Sand & $\begin{array}{c}\text { \% Silt } \\
5-10 \mathrm{~cm}\end{array}$ & \% Clay \\
\hline Macedonia & 24.2 & 67.9 & 7.9 \\
Clarksville & 21.2 & 67.5 & 11.3 \\
Coulstone & 53.5 & 39.4 & 7.1 \\
Captina & 14.4 & 76.1 & 9.5 \\
Doniphan & 31.6 & 52 & 16.4 \\
Poynor & 2 & 66 & 12 \\
Wilderness & 16.1 & 75.7 & 8.2 \\
Viraton & 17 & 70 & 13 \\
\hline
\end{tabular}

Table 4. Reported soil texture for 20-30 cm of the soil profile (USDA-WSS, 2017).

\begin{tabular}{cccc}
\hline Soil Series & \% Sand & $\begin{array}{c}\text { \% Silt } \\
\text { subsoil 20-30 cm }\end{array}$ & \% Clay \\
\hline Macedonia & 14.7 & 60.1 & 25.2 \\
Clarksville & 23 & 65.8 & 11.2 \\
Coulstone & 49.7 & 41 & 9.3 \\
Captina & 6.5 & 63 & 30.5 \\
Doniphan & 28.4 & 54.7 & 16.9 \\
Poynor & 10.5 & 70.5 & 19 \\
Wilderness & 15.7 & 72.1 & 12.2 \\
Viraton & 10 & 62 & 28 \\
\hline
\end{tabular}

\section{Climate and Hydrology}

The Ozarks are temperate and humid with temperatures ranging from 15 to 18 degrees Celsius. Average annual rainfall ranges from 100 to $200 \mathrm{~cm}$ (USDA-NCSS, 2005). Intense rainfall is most common from March to June due to moisture-laden air masses from the Gulf of Mexico (Adamski et al., 1995). 
The Big Barren watershed is dominated by karst terrain with rolling hills, steep valleys and entrenched meandering streams (Ornoff et al., 2001). The area is characterized by springs, caves and sinkholes (Ornoff et al., 2001). Many stream channels run dry because of the extensive karst systems that dominate the landscape of the Ozarks, whereas other areas are supplied with substantial baseflow from springs (Ornoff et al., 2001).

Runoff in the Ozarks depends on the precipitation regime, topography, geology, soils and other factors (Adamski et al., 1995). Streamflow in the Ozarks is affected by precipitation amounts, karst geology and topography, vegetation, drainage area, channel slope and length, and season (Adamski et al., 1995).

\section{Land Use and Vegetation}

The history of the Eleven-Point Ranger District of Mark Twain National Forest has played a central role in effecting the current composition of vegetation in the area. Disturbances such as human activity, natural and anthropogenic fire have largely influenced forest structure and vegetation. Pine stands covered more than 4 million acres of Missouri Ozarks before European settlement (Ladd et al., 2007). The forest was heavily logged during European settlements for growth and expansion. Increasing demand for timber harvest was facilitated by railways (Guyette and Larsen, 2000). In addition to logging, fire suppression during this time allowed understory growth and invasive species to multiply and grow, which replaced and out-competed shortleaf pine trees (Cunningham, 2007). Forest structure shifted from pine-oak dominated stands to oak-hickory dominated forests. 
The forests have been managed for the past 75 years, where the main objective was the re-establishment and protection of native pines (Cunningham, 2007). In 2006, the Ozark-Highlands Pine-Oak Woodland Restoration Partnership began with over 20 state, federal and non-governmental organizations (Nigh, 2007). Since then the partnership has received grants to continue restoration activities on more than 6500 acres of land (Nigh, 2007).

In 2012, the Missouri Collaborative Forest Landscape Restoration Project began (USDA-FS, 2012). Local history and research of the Mark Twain National Forests identified fire frequency intervals of every 3-5 years, which were common before preEuropean settlements (Guyette and Larsen, 2000). The CFLRP's goal is to restore the forest to its original shortleaf, pine-oak woodland conditions by using a combination of silviculture and prescribed burning (USDA-FS, 2012). The prescribed burns follow historic fire frequency intervals where burns occurred every 3-5 years (Appendix B). 


\section{CHAPTER 3 - METHODS}

Assessments of prescribed burning on forest structure and forest-soil conditions

are most effectively done using a combination of Geographic Information Systems (GIS), field, laboratory, statistical and modeling methods. GIS was used for site selection and data storage. Field methods included subplot design following the Forest Inventory and Analysis (FIA) National Core Field Guide, soil sampling in $5 \mathrm{~cm}$ increments using a bulk density ring, and forest characteristics assessment forms. Site and subplot locations were collected using a Global Positioning System (GPS). Soil samples were prepped in the laboratory and analyzed for BD, percent $\mathrm{OM}$ and grain size. Statistical analysis using SPSS involved descriptive statistics and difference of means using one-way ANOVA. The Universal Soil Loss Equation model was used to estimate average annual soil loss erosion rates for burned and unburned stands.

\section{Geospatial}

Databases. Geospatial databases and ArcGIS maps were used to randomize site selection and store forest and soil characteristics data. Data were downloaded and imported into ArcMap from MSDIS, OEWRI server, USDA-NRCS geospatial data gateway, and the USFS Geodata Clearinghouse. This data is stored on the OEWRI server. The MSDIS and OEWRI server data contained a delineated watershed for Big Barren and Missouri roads and streams.

Soil data were obtained from the USDA-NRCS geospatial data gateway for Carter, Oregon and Ripley counties (USDA-NRCS, 2017). The Macedonia soil series 
was selected as the control soil for both burned and unburned sites because it occurred most frequently on upland sites with the least amount of rock fragments. The Macedonia soils within the unburned areas will serve as the baseline for soil characteristics.

Prescribed burning polygons were obtained from the FSGeodata Clearinghouse (USDA-FS, 2017a). The prescribed burn polygons were named by the last year in which they were burned, and how many times they have been burned (frequency). The unburned sites within the watershed have no polygons (Figure 4).

Forest vegetation and management data were also obtained from the FSGeodata Clearinghouse. Information such as stand type and site management were incorporated into ArcGIS. Sites were classified as oak, pine or mixed using the attribute table from the FSGeodata Clearinghouse. Management data was recorded for descriptive information. (Appendix B).

Site Location. Stratified random sampling was used to locate monitoring sites. Random points were created by adding transect points every 200 meters along roads that intersected the Macedonia soil series polygons in the burned and unburned areas. Points located within burn areas of different years, and unburned areas were assigned a set of numbers. A random number generator was used to eliminate sampling bias by generating 3-7 points for each burned area and unburned area to create a total of 30 sampling sites across the watershed (Stattrek.com) (Figure 4). Extra points were randomly generated incase access to a site was limited. 


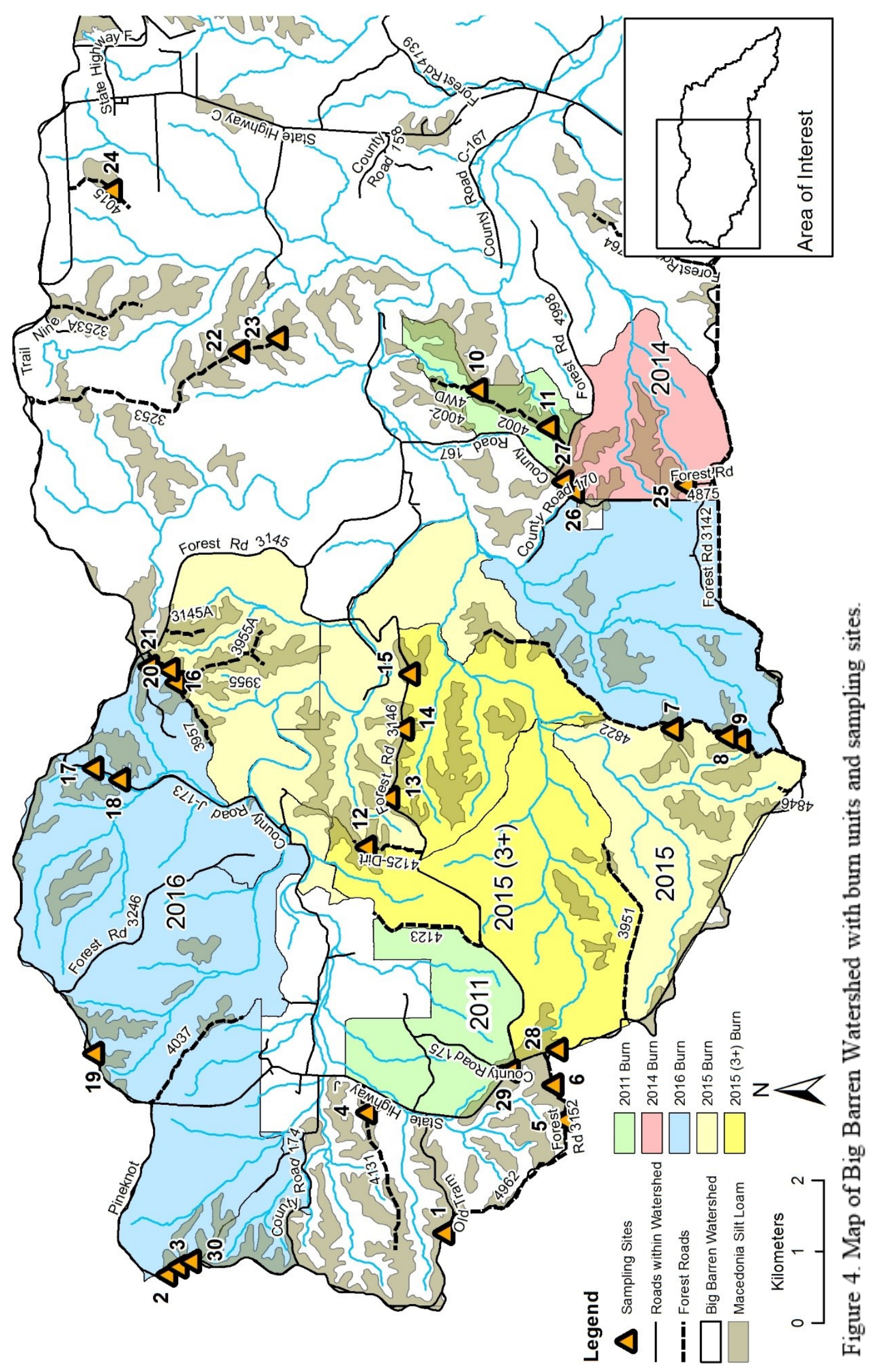




\section{Field}

Site Layout and Design. In October 2015 sites were visited for field reconnaissance and subplot setup. GPS points were taken at each site and imported into ArcMap to ensure accuracy of the sampling location (Figure 4). Sites were numbered in the order in which they were setup and sampled. At each site, distances between 50 to $200 \mathrm{~m}$ were walked into the forest from the forest roads to hit the center of the Macedonia soil series area. A stake was then hammered into the ground and labeled by its site name (1-30) (Appendix C-10). This located the center of subplot 1. Subplot layouts follow the diagram designed by the United States Forest Service, Forest and Inventory Analysis where one site has 4 subplots (FIA, 2014). Centers for the other 3 subplots are measured $37 \mathrm{~m}$ from subplot 1 following azimuths of $0 / 360^{\circ}$ for subplot $2,120^{\circ}$ for subplot 3 and $240^{\circ}$ for subplot 4 (Figure 5). Centers at each subplot were marked with an orange spray-painted rock as a benchmark. A GPS location and photo was collected for each subplot. A white wooden sign with the subplot number was attached to a witness tree at each subplot. Witness tree locations were recorded by taking a bearing with the recorders back to the tree and measuring the distance from the benchmark to the tree (Appendix D). These signs are easy to locate and are an additional aid to finding sites. Field sites were visited four different times for site design and setup, soil and vegetation measurements, post burn measurements, temporal and replicate measurements.

Field Visits. In October 2015, soil and leaf litter samples were collected at $28 \mathrm{~m}$ along the $37 \mathrm{~m}$ transect measured from the center of subplot 1 to subplots 2, 3 and 4 . Soil samples were collected using a $5 \mathrm{~cm}$ by $5 \mathrm{~cm}$ steel BD sampling ring (Appendix C-8). The soil samples were collected in increments of $0-5 \mathrm{~cm}$ and $5-10 \mathrm{~cm}$, collecting an A 
horizon and an A/E Horizon (USDA-NCSS, 2005). In certain locations where the soil was less rocky, sub soil samples were taken using a shovel at a depth of 20-30 cm. Litter and duff depth measurements and samples were taken using a folding ruler and a litter sampling frame with a diameter of $30.5 \mathrm{~cm}$ (Appendix C-12) (Forest Inventory and Analysis National Core Field Guide, 2014). Information about the slope at each subplot was gathered using a clinometer.

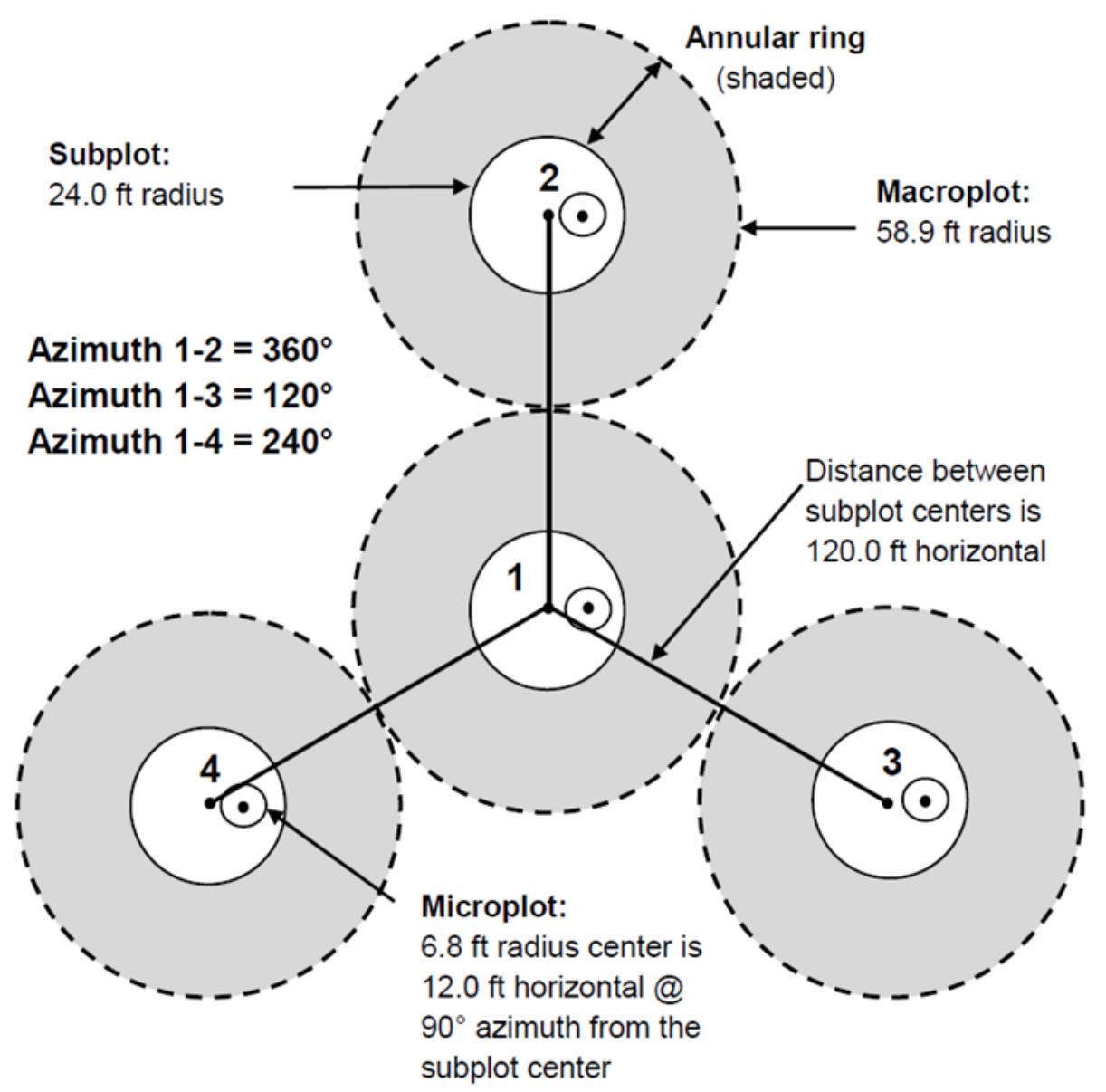

Figure 5. USFS Forest Inventory and Analysis subplot sampling layout. 
In December 2015, sites were re-visited to collect subplot condition and vegetation data using forms adapted from FIA 2014 (Appendix E). Forest conditions were measured in all four subplots, which had a radius of $7.3 \mathrm{~m}$, measured from the center (37 $\mathrm{m}$ from subplot one, for subplots 2,3 , and 4). This included timber harvest class, fire history (number of times burned) and estimations of percent ground cover. Actual measurements within each subplot included litter depth and duff depth. Tree species and diameter breast height (DBH) greater than $0.13 \mathrm{~m}$ were recorded. Coarse/large woody debris greater than $0.1 \mathrm{~m}$ in diameter were measured for diameter and length. Seedling and sapling tallies were measured within a microplot which was measured $3.7 \mathrm{~m}$ east from the center of the main subplot and had a radius of $2.1 \mathrm{~m}$. Seedlings less than $0.025 \mathrm{~m}$ diameter and saplings with diameters between 0.025 to 0.13 $\mathrm{m}$ in diameter were tallied and recorded (Appendix E).

Twelve of the thirty sites sampled were burned in March 2016, including one site which had never been burned. In May 2016, these twelve sites were re-visited to collect soil and litter samples from one subplot at each of the sites in the first $0-5,5-10 \mathrm{~cm}$ and $20-30 \mathrm{~cm}$ of the soil. The leaf litter and duff layer depths were measured and collected, and data for CWD and seedling and sapling were recorded.

During the final sampling event in October 2016, the twelve burned sites previously sampled in October 2015/December 2015 and May 2016 were sampled again as well as three unburned sites. The purpose of this final sampling event was to assess temporal variations and complete replicate sampling for forest and soil condition measurement errors. Of the fifteen sites, seven were duplicates, which included three unburned and four burned sites with different stand types (oak, pine, mixed). Duplicate 
sites were measured twice in the same day at different times and by different workers. Each team collected soil samples at subplots 2,3 and 4 for the first $0-5 \mathrm{~cm}$ of the soil, measured and collected litter and duff layer depths, measured DBH, CWD, and completed seedling and sapling tallies. Each sampling event followed FIA, 2014 methods. Figure 6 includes a general over view of site visits and accomplishments.

Method Error. Relative percent difference was calculated for each variable measured at the seven duplicate sites for subplot error. The average of the subplot errors was recorded to obtain site error. Site errors are reported in Appendix F for relative percent difference. Sampling and spatial variability were high for the procedures used in this study. Basal area ranges from 8-35\% RPD. Litter depths range from 12-33\% RPD and duff depths range from $10-45 \%$ RPD. Measurements such as seedling and sapling densities and CWD have high RPDs with ranges from 30-170\% for seedlings and sapling densities and $4-115 \%$ for CWD volume/area. It is possible that these high errors influenced the no significant difference results obtained from one-way ANOVA. 


\section{October 2015}

-Site reconnaissance

-GPS points

-Subplot setup

-Slope percent

-Litter and duff depth measurements

-Soil sampling using bulk density ring

December 2015
-Return to sites to complete subplot setup
-Post MSU signs on witness trees
-GPS points
-Complete subplot condition and vegetation
forms following FIA Phase 2 guidelines

March 2016

-Prescribed burning by USFS; 12 sites

burned

-12 burned sites visited; soil samples were collected at one subplot per site; subplots measured were rotated as sites were visited

-Modified subplot condition forms were used to assess immediate effects of burning

-Modified form included: litter and duff depths, CWD tallies, seedling/sapling tallies

\section{October 2016}

-Re-visited 12 sites burned in March and 3 unburned sites for duplicate field measurements

-Completed duplicate sampling at 7 of the 12 sites (3 unburned and 4 burned)

-Sites were duplicated the same day; soil (0-5 cm) samples were only collected at duplicate sites for each subplot

-Used new modified subplot condition forms at all sites

-Modified form included: litter and duff depths, tree and CWD tallies, seedling/sapling tallies

Figure 6. Site visits and accomplishments flowchart. 


\section{Laboratory}

Soil samples were processed at Missouri State University in the geomorphology laboratory. Samples were dried in an oven at $60^{\circ} \mathrm{C}$ for 24 to 48 hours, or until all moisture had been removed, immediately after a sampling event. After drying, the soil samples were prepped for analysis by using a mortar and pestle for disaggregation and sieved using a $2 \mathrm{~mm}$ sieve to remove rocks and larger particles such as roots. Laboratory procedures followed standard operating methods and each analysis consisted of quality assurance checks to test the precision and accuracy of the method.

Bulk Density. Bulk density is calculated as dry soil mass $(<2 \mathrm{~mm})$ divided by soil volume (USDA Kellogg Soil Survey, 2014). To calculate BD, rocks/roots from each sample were removed and weighed. This weight was subtracted from the total sample weight to obtain soil mass $(\mathrm{g})$. The rocks and roots were then placed into a graduated cylinder with a known volume of water. The difference in the volume of water after the rocks/roots were added was recorded. This volume was subtracted from the total known volume of the BD ring, which resulted in soil volume $\left(\mathrm{cm}^{3}\right)$. Finally, the soil mass was divided by soil volume (USDA-NRCS, 2004). Field duplicates collected in October 2016 were under $40 \%$ relative percent difference (RPD). Subsoil samples were not tested for $\mathrm{BD}$ because they were not collected using a BD ring. The remaining soil sample was analyzed for OM content and grain size analysis.

Organic Matter. Organic matter content in the soil was analyzed by using the loss on ignition technique (LOI) following procedures defined in the Soil Science Society of America Methods of Soil Analysis (Sparks, 1996, p. 1004), and the OEWRI standard operating procedure (OEWRI, 2007). The analysis is completed by heating crucibles at 
$105^{\circ} \mathrm{C}$ for four hours in an oven to remove moisture. Each crucible was weighed and then a 5 gram (g) soil sample was added and the weight was recorded. The samples and crucibles were first placed in the oven at $105^{\circ} \mathrm{C}$ for two hours to remove any excess soil moisture. After two hours the samples were removed and allowed to cool in a desiccator. The samples were weighed for the pre-burn weight before the samples were placed in a muffle furnace and burned at $600^{\circ} \mathrm{C}$ for 8 hours. Crucibles were allowed to cool in the desiccator, then weighed again. The LOI is the difference between the pre-burn weight and the final weight divided by the initial weight and multiplied by 100 :

$\left[\% O M=\frac{\text { Pre-ignition weight-post ignition weight }}{\text { pre-ignition weight }} * 100\right]$. Thirty samples and four duplicates were tested during each run. All laboratory duplicates were under 5\% RPD. Field duplicates were under 40\% RPD.

Texture. Grain size or texture analysis was conducted using the LS 13321 Laser Diffraction Particle Size Analyzer (Eshel et al., 2004; OEWRI, 2008). A $0.20 \mathrm{~g}$ of the soil sample was pretreated. Pretreatment included OM digestions in a 30\% $\mathrm{H} 2 \mathrm{O} 2$ and $1 \%$ acetic acid solution. The sediment was dispersed in a 5\% sodium-hexametaphosphate solution prior to analysis (OEWRI, 2008). Thirty samples were analyzed at a time, including three standards and two duplicates. Standards were under 15\% RPD and duplicate samples were under 25\% RPD. Grain size analysis can help scientists understand erosion processes occurring on the soil due to particle sizes and distribution (McLaren and Bowles, 1985). Additionally, mean particle diameters should be relatively similar across soil samples because the soil type was held constant. 


\section{Statistical}

Descriptive statistics and one-way ANOVA were used to analyze statistical significance using IBM SPSS Statistical software. Descriptive statistics include measures of central tendency (mean), and measures of dispersion (standard deviation, standard error, variance, minimum and maximum).

One-way ANOVA was used to determine if there were any statistically significant differences between the means of two or more independent groups. The independent groups for this study were burned versus unburned sites, and burned and unburned stand types (oak, pine, mixed). There are three assumptions for one-way ANOVA: 1) Observations between and within samples are random and independent, 2) The observations in each category are normally distributed and 3) The population variances are assumed equal for each category (Rogerson, 2014). To test that the third assumption is met, a test of homogeneity of variances can be used. The significance for each of the dependent variables in this test must be greater than 0.05 to assume equal variances. If the assumptions are not satisfied, one option is to continue with the analysis of variance, especially if the results are expected and the analyst has confidence in the results. ANOVA is considered to be robust with respect to deviations from the assumptions of normality and homoscedasticity (equal variances) (Rogerson, 2014). Therefore, the results can still be used effectively if the assumptions are reasonably close to being satisfied (Rogerson, 2014). A test of homogeneity of variances was used to test the assumptions in SPSS. All assumptions were met for one-way ANOVA difference of means. 


\section{Universal Soil Loss Equation}

The Universal Soil Loss Equation (USLE) was developed in 1965 by Wischmeier and Smith, and was originally used to determine soil loss on agricultural fields (Renard et al., 2010). Multiple revisions have been made to include a variety of management practices (Renard et al., 2010). Early versions of the equation were derived from measurements of precipitation, runoff and soil loss (Renard et al., 2010). It has since then been modified to include slope length and steepness, as well as various conservation and soil cover management practices (Renard et al., 2010).

The USLE predicts the average annual soil loss in metric tons per hectare using inputs of rainfall pattern, soil type, topography, and ground cover and conservation management practices. In this study, the USLE was used to estimate average annual soil loss in metric tons per hectare $(A)$ for burned and unburned oak and pine stands. The equation accounts for rainfall erosivity $(R)$, soil erodibility $(K)$, slope length and steepness $(L S)$, cover management $(C)$, conservation management $(P)$, and is calculated as $A=R \times K \times L S \times C \times P($ Wade and Trimble, 2004). All values are unit-less except $\mathrm{R}$ and $\mathrm{K}$ values which have units of hundreds of foot-ton-inches/acre/hour and ton-acre-hour/hundred foot-tons/inch. For the purposes of this study all variables were held constant except $K$.

Rainfall erosivity $(R)$ was held constant because the value accounts for rainfall from February to August for the southeastern part of Missouri. The month range February to August was chosen because February is the month before prescribed burns occur in Mark Twain National forest, and August nears the end of the intense rainfall season (Adamski et al., 1995). Rainfall erosivity values $(R)$ were obtained using the $R$ 
distribution map of the U.S. and the monthly $R$ distribution graph in Wade and Trimble, 2004. The $R$ values were compared to the EPA rainfall erosivity calculator results (EPA, 2017). The RPD between the two sources was $8 \%$. A value of 177 was used for rainfall erosivity (EPA, 2017). Slope length and steepness $(L S)$ was held constant because slope steepness and length were relatively the same among sites. The cover management $(C)$ factor commonly used for forests with a range of $70-100 \%$ vegetation and ground cover is 0.004 (NRCS, 2017). Therefore, this value was held constant. Finally, $P$ or conservation management, was held constant. The $P$ factor is important because it provides information about conservation and erosion control practices. However, $P$ values were created for conservation/control practices on agricultural lands. There are many applications in which no conservation/control practices will be used. In this case a $P$ factor of one is appropriate (Wade and Trimble, 2004). Therefore, for forested lands a $P$ factor of one is used. The soil erodibility or $K$ factor was not held constant. Soil erodibility values were obtained using the nomograph in Wade and Trimble (2004) and using percent sand and silt values measured in the texture analysis (Appendix $\mathrm{G}$ and $\mathrm{H}$ ). 


\section{CHAPTER 4 - RESULTS AND DISCUSSION}

The purpose of this chapter is to present and discuss the results of this study. Prescribed burning effects are examined using graphical representation and one-way ANOVA difference of means. To further assess prescribed burning effects on forest soil conditions, the Universal Soil Loss Equation (USLE) is used to estimate average annual sediment loss.

\section{General Site Characteristics}

Forests in Missouri have been managed for the past 75 years to favor pine regeneration (Appendix B) (Cunningham, 2007). Many areas throughout the watershed are managed with silvicultural practices only. For example, Site 1 has never been burned, however it was commercially thinned in 2011 (Appendix B). Silvicltural practices include improvement cuts, sanitation cuts, salvage cuts, clear-cutting, and commercial thinning (Appendix B). These various management practices reduce basal area (BA) and increase CWD throughout the forests. All sites sampled were located on broad upland ridges with gentle slopes. Slopes ranged from 1-7\%, with a median slope around 4\% (Tables 5-7). 


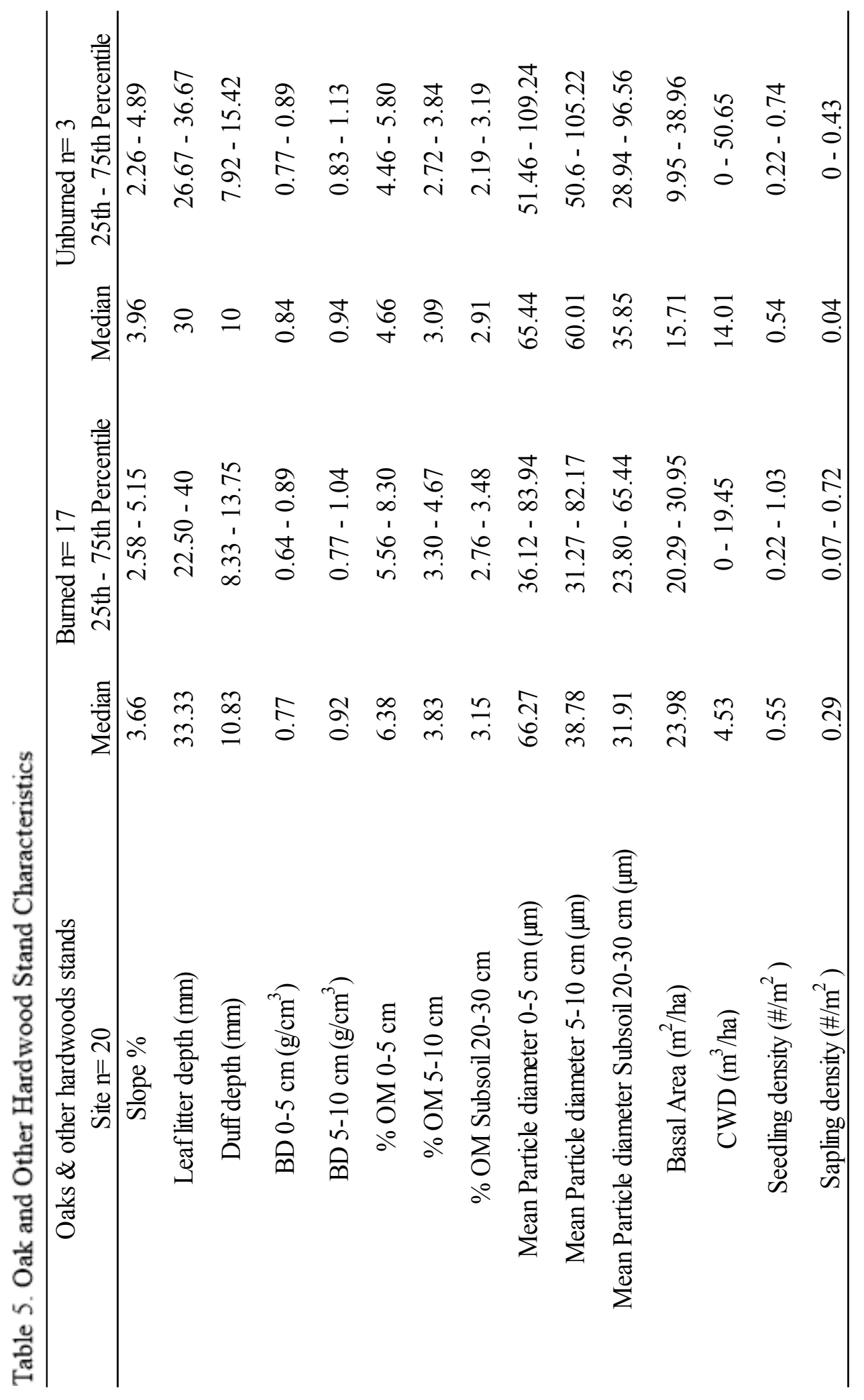




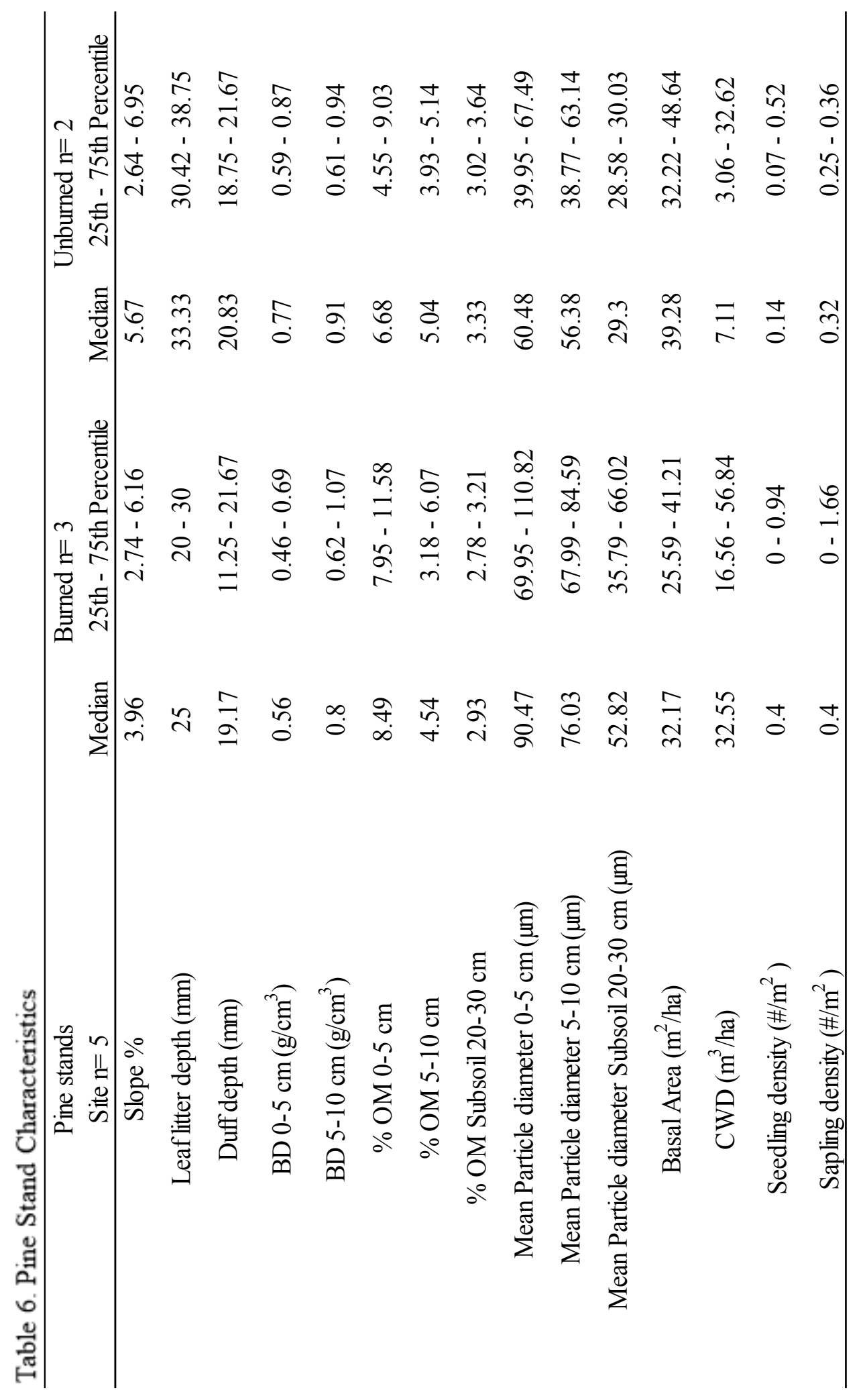




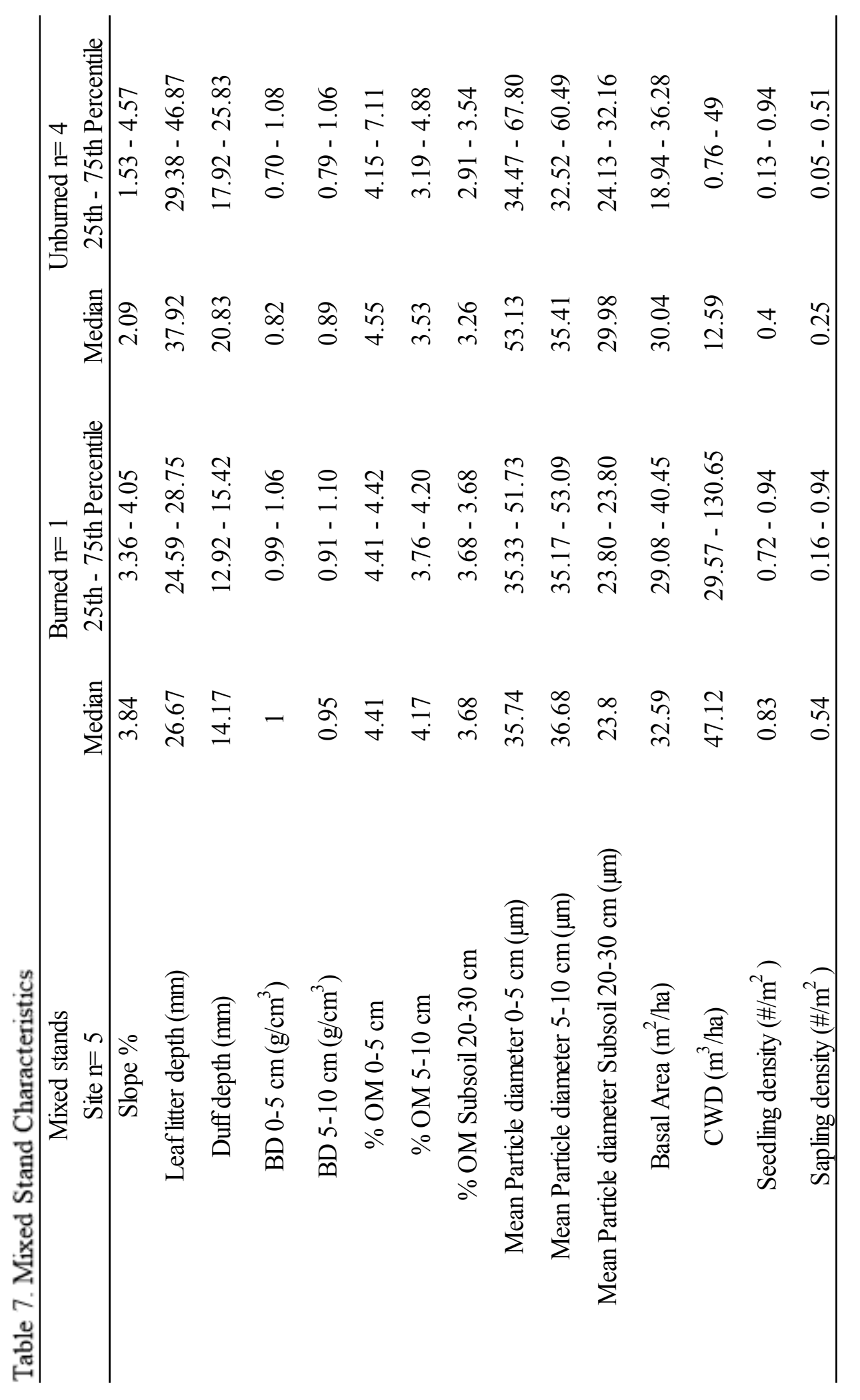


Basal Area. Median BA among the 30 sites sampled was $32 \mathrm{~m}^{2} /$ ha (Tables 5-7). Fully stocked stands in Missouri typically have a maximum BA of $32-40 \mathrm{~m}^{2} / \mathrm{ha}$ (Gingrich, 1967; Blizzard et al., 2007). There were no statistically significant differences among BA between burned and unburned sites (Table 8). Reilly et al (2016), also found no significant effect of prescribed burning on BA. However, BA was significantly different among stand types (Table 9). The differences are likely due to variations in natural forest growth patterns and varying forest management practices previously described (Kolaks et al., 2004; USFS-FSM, 2014) (Figure 7 and Appendix B).

Table 8. Significant values are in bold as determined by one-way ANOVA; burned versus unburned (Mean $\pm \mathrm{SD}$ ).

\begin{tabular}{cccc}
\hline & Burned & Unburned & $p$-value \\
\hline Litter depth $(\mathrm{mm})$ & $33.5 \pm 8.7$ & $40.5 \pm 9.5$ & $\mathbf{0 . 0 0 0}$ \\
Duff depth $(\mathrm{mm})$ & $12.5 \pm 5.8$ & $18.5 \pm 8$ & $\mathbf{0 . 0 0 0}$ \\
OM (\%) $0-5 \mathrm{~cm}$ & $7.4 \pm 3$ & $5.96 \pm 2.3$ & $\mathbf{0 . 0 3 1}$ \\
OM $(\%) 5-10 \mathrm{~cm}$ & $4.2 \pm 1.2$ & $4 \pm 1.2$ & 0.535 \\
BD $\left(\mathrm{g} / \mathrm{cm}^{3}\right) 0-5 \mathrm{~cm}$ & $0.75 \pm 0.2$ & $0.84 \pm 0.2$ & $\mathbf{0 . 0 3 9}$ \\
BD $\left(\mathrm{g} / \mathrm{cm}^{3}\right) 5-10 \mathrm{~cm}$ & $0.89 \pm 0.22$ & $0.91 \pm 0.21$ & 0.695 \\
Grain size $(\mu \mathrm{m}) 0-5 \mathrm{~cm}$ & $70.5 \pm 33.4$ & $61 \pm 26.5$ & 0.193 \\
Grain size $(\mu \mathrm{m}) 5-10 \mathrm{~cm}$ & $58.7 \pm 31.6$ & $56.6 \pm 27.1$ & 0.767 \\
Basal area $\left(\mathrm{m}^{2} / \mathrm{ha}\right)$ & $27.76 \pm 11.64$ & $28.7 \pm 14$ & 0.146 \\
CWD $\left(\mathrm{m}^{3} / \mathrm{ha}\right)$ & $22 \pm 42.8$ & $33.3 \pm 52.7$ & 0.219 \\
Sapling density $\left(\# / \mathrm{m}^{2}\right)$ & $0.57 \pm 0.72$ & $0.38 \pm 0.6$ & 0.151 \\
Seedling density $\left(\# / \mathrm{m}^{2}\right)$ & $0.72 \pm 0.73$ & $0.5 \pm 0.46$ & 0.095 \\
\hline
\end{tabular}


Table 9. Significant values are in bold as determined by one-way ANOVA; Burned and unburned differences among stand types (Mean \pm SD).

\begin{tabular}{|c|c|c|c|c|c|}
\hline & & Burned & $p$-value & Unburned & $p$-value \\
\hline \multirow{3}{*}{ Litter depth (mm) } & Oak & $34.9 \pm 8.9$ & & $36.8 \pm 7.1$ & \multirow{3}{*}{0.049} \\
\hline & Pine & $27.1 \pm 5.0$ & 0.009 & $37.7 \pm 8.3$ & \\
\hline & Mixed & $29.2 \pm 3.2$ & & $45 \pm 10.5$ & \\
\hline \multirow{3}{*}{ Duff depth (mm) } & Oak & $11.6 \pm 5.3$ & & $11.9 \pm 5.4$ & \multirow{3}{*}{0.001} \\
\hline & Pine & $16.9 \pm 7.2$ & 0.009 & $20 \pm 3.5$ & \\
\hline & Mixed & $14.2 \pm 2.2$ & & $22.7 \pm 8.3$ & \\
\hline \multirow{3}{*}{$\mathrm{OM}(\%) 0-5 \mathrm{~cm}$} & Oak & $7.1 \pm 2.3$ & & $5.7 \pm 2.6$ & \multirow{3}{*}{0.573} \\
\hline & Pine & $10.1 \pm 5.1$ & 0.003 & $6.7 \pm 2.7$ & \\
\hline & Mixed & $4.4 \pm 0.02$ & & $5.7 \pm 2$ & \\
\hline \multirow{3}{*}{$\mathrm{OM}(\%) 5-10 \mathrm{~cm}$} & Oak & $4.1 \pm 1.1$ & & $3.4 \pm 0.9$ & \multirow{3}{*}{0.111} \\
\hline & Pine & $4.9 \pm 1.8$ & 0.205 & $4.7 \pm 1.3$ & \\
\hline & Mixed & $3.9 \pm 0.5$ & & $4.1 \pm 1.2$ & \\
\hline \multirow{3}{*}{$\mathrm{BD}\left(\mathrm{g} / \mathrm{cm}^{3}\right) 0-5 \mathrm{~cm}$} & Oak & $0.75 \pm 0.17$ & & $0.84 \pm 0.2$ & \multirow{3}{*}{0.508} \\
\hline & Pine & $0.6 \pm 0.22$ & 0.002 & $0.76 \pm 0.2$ & \\
\hline & Mixed & $1.0 \pm 0.08$ & & $0.9 \pm 0.2$ & \\
\hline \multirow{3}{*}{$\mathrm{BD}\left(\mathrm{g} / \mathrm{cm}^{3}\right) 5-10 \mathrm{~cm}$} & Oak & $0.89 \pm 0.21$ & & $0.97 \pm 0.2$ & \multirow{3}{*}{0.221} \\
\hline & Pine & $0.86 \pm 0.3$ & 0.526 & $0.8 \pm 0.2$ & \\
\hline & Mixed & $1.0 \pm 0.2$ & & $0.93 \pm 0.2$ & \\
\hline \multirow{3}{*}{ Grain size $(\mu \mathrm{m}) 0-5 \mathrm{~cm}$} & Oak & $68.5 \pm 33.8$ & & $75.8 \pm 32.8$ & \multirow{3}{*}{0.121} \\
\hline & Pine & $90.4 \pm 26.5$ & 0.081 & $54.6 \pm 16.2$ & \\
\hline & Mixed & $46.1 \pm 18.7$ & & $53.2 \pm 22.1$ & \\
\hline \multirow{3}{*}{ Grain size $(\mu \mathrm{m}) 5-10 \mathrm{~cm}$} & Oak & $57.2 \pm 33.8$ & & $70.6 \pm 31.4$ & \multirow{3}{*}{0.124} \\
\hline & Pine & $71.1 \pm 16.8$ & 0.385 & $56.3 \pm 23.4$ & \\
\hline & Mixed & $46.6 \pm 19.8$ & & $46.3 \pm 22.2$ & \\
\hline \multirow{3}{*}{ Basal area $\left(\mathrm{m}^{2} / \mathrm{ha}\right)$} & Oak & $26.17 \pm 10.75$ & & $23.71 \pm 15.67$ & \multirow{3}{*}{0.055} \\
\hline & Pine & $33.68 \pm 12.34$ & 0.030 & $38.63 \pm 13.44$ & \\
\hline & Mixed & $17.35 \pm 8.68$ & & $27.48 \pm 11.04$ & \\
\hline
\end{tabular}


Table 9 continued. Significant values are in bold as determined by one-way ANOVA; Burned and unburned differences among stand types (Mean \pm SD).

\begin{tabular}{cccccc}
\hline & & Burned & $p$-value & Unburned & $p$-value \\
\hline & Oak & $13.5 \pm 20.3$ & & $26.2 \pm 28.4$ & \\
CWD $\left(\mathrm{m}^{3} / \mathrm{ha}\right)$ & Pine & $39.6 \pm 31.8$ & $\mathbf{0 . 0 0 0}$ & $21.3 \pm 27$ & 0.520 \\
& Mixed $113.1 \pm 155.02$ & & $44.6 \pm 73$ & \\
& Oak & $0.51 \pm 0.65$ & 0.191 & $0.28 \pm .45$ & 0.763 \\
Sapling density $\left(\# / \mathrm{m}^{2}\right)$ & Pine & $0.92 \pm 1.01$ & & $0.37 \pm 0.3$ & \\
& Mixed & $0.56 \pm 0.54$ & & $0.45 \pm 0.78$ & \\
& Oak & $0.67 \pm 0.54$ & 0.474 & $0.58 \pm 0.44$ & 0.407 \\
Seedling density $\left(\# / \mathrm{m}^{2}\right)$ & Pine & $0.95 \pm 1.5$ & & $0.31 \pm 0.31$ & \\
& Mixed & $0.83 \pm 0.27$ & & $0.54 \pm 0.54$ & \\
\hline
\end{tabular}

$$
\begin{array}{ll}
\square \text { unburned Dec } 2015(\mathrm{n}=9) & \text { burned }>1 \text { year Dec } 2015(\mathrm{n}=21) \\
\square \text { months Oct } 2016(\mathrm{n}=12) & \text { unburned Oct } 2016(\mathrm{n}=3)
\end{array}
$$

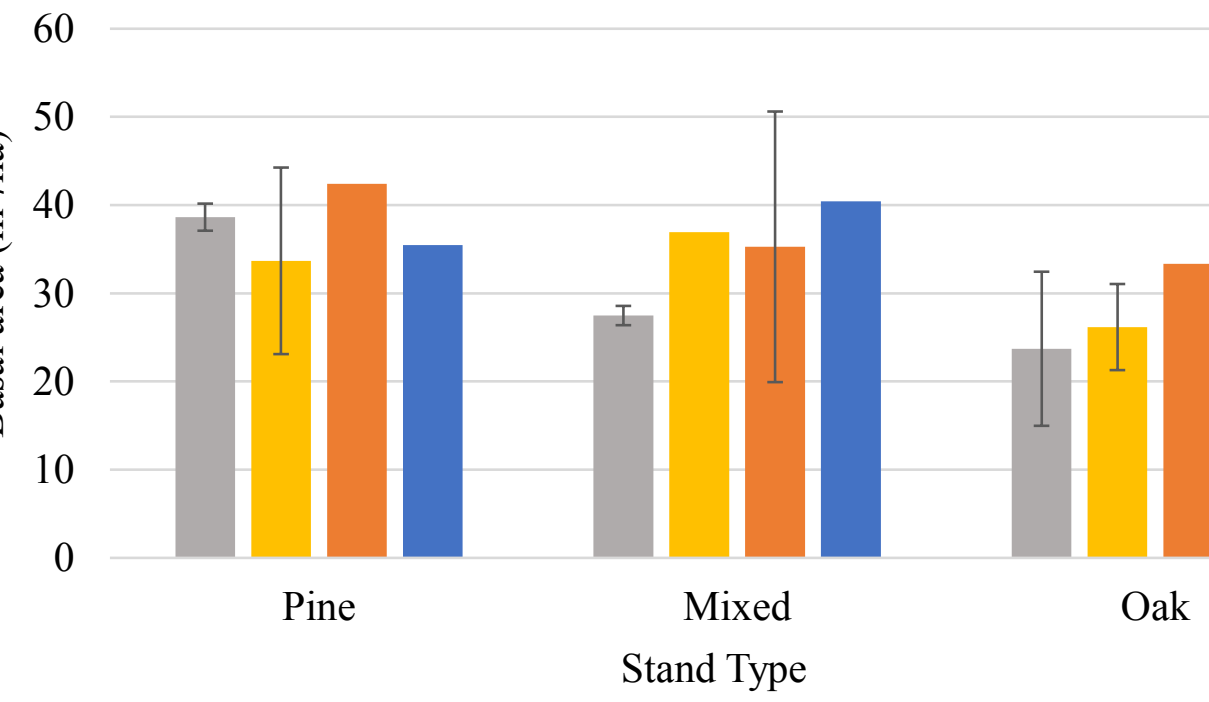

Figure 7. Basal area among stand types and time sampled. 
Coarse Woody Debris. Understory cover such as coarse woody debris (CWD) and seedling and sapling densities vary naturally by stand type, season and with varying management practices such as timber stand improvement (TSI) and prescribed burning (Tiedemann et al., 2000; Wang et al., 2005). There were no statistically significant differences for prescribed fire effects between burned and unburned sites for CWD ( $\mathrm{p}$ $>0.05$ ) (Table 8). However, there were statistically significant differences for CWD among burned stand types (oak, pine, mixed), but not among unburned stand types (Table 9). In general pine and mixed stands that have been burned tend to have more CWD than oak stands (Figure 8 and Tables 5-7). Results suggest that prescribed burns themselves are not consuming CWD. The variability of CWD among stand types is likely due to varying silvicultural practices used among sites (Gwaze et al., 2007 and Guyette et al., 2007) (Appendix B).

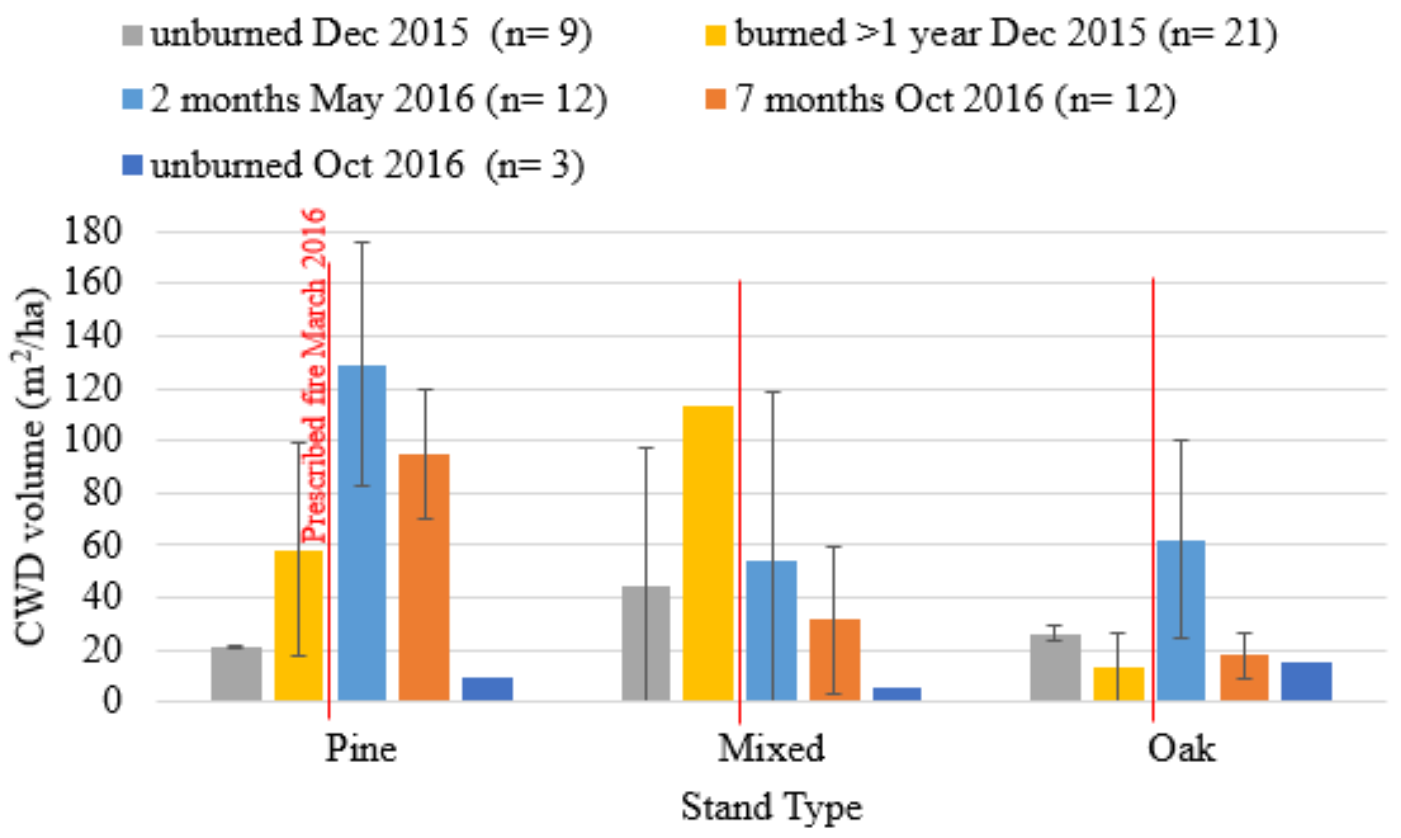

Figure 8. Coarse woody debris by stand type and time sampled. 
Canopy and Understory Cover. During this study, only one site out of 30 was severely burned with total canopy consumption. All other sites maintained total tree canopy coverage except during leaf-off seasons (Appendix C). Site 30 is the only site with canopy consumption. It has been burned four times since 2009 (Appendix B). It is unknown which prescribed burn prior to 2016 consumed the canopy (Appendix C-13 and C-14).

There were no statistically significant differences for prescribed fire effects between burned and unburned sites for seedling/sapling densities. However, burned sites tend to have higher densities of seedlings and saplings than unburned sites (Table 8) (Wang et al., 2005). During May, there were large increases of seedling and sapling densities compared to winter and fall months (Figures 9 and 10). Unburned sites were not sampled during May; it is unclear if the increases in seedling and sapling densities are related solely to the season, or if prescribed burning enhances seedling/sapling growth. Lack of significance for seedling/sapling densities are likely due to high natural variability (Tiedemann et al., 2000) and high field-method sampling errors coupled with other types of forest management outside of prescribed burning (Appendix B and F). 
unburned Dec $2015(\mathrm{n}=9)$

- 2 months May $2016(\mathrm{n}=12)$

- unburned Oct $2016(\mathrm{n}=3)$
- burned $>1$ year Dec $2015(\mathrm{n}=21)$

7 months Oct $2016(\mathrm{n}=12)$

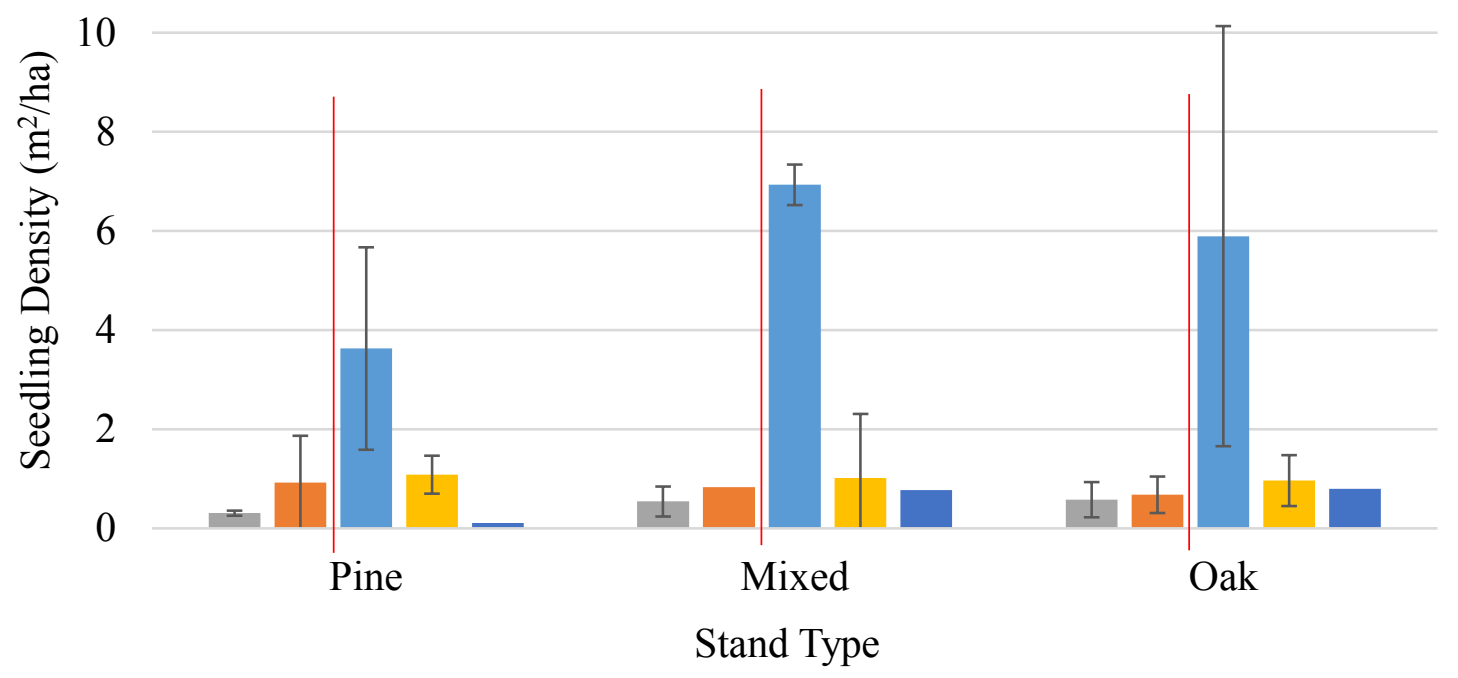

Figure 9. Seedling density by stand type and time sampled.

unburned Dec $2015(\mathrm{n}=9)$

2 months May $2016(\mathrm{n}=12)$

u unburned Oct $2016 \quad(\mathrm{n}=3)$ a burned $>1$ year Dec $2015(\mathrm{n}=21)$

7 months Oct $2016(\mathrm{n}=12)$

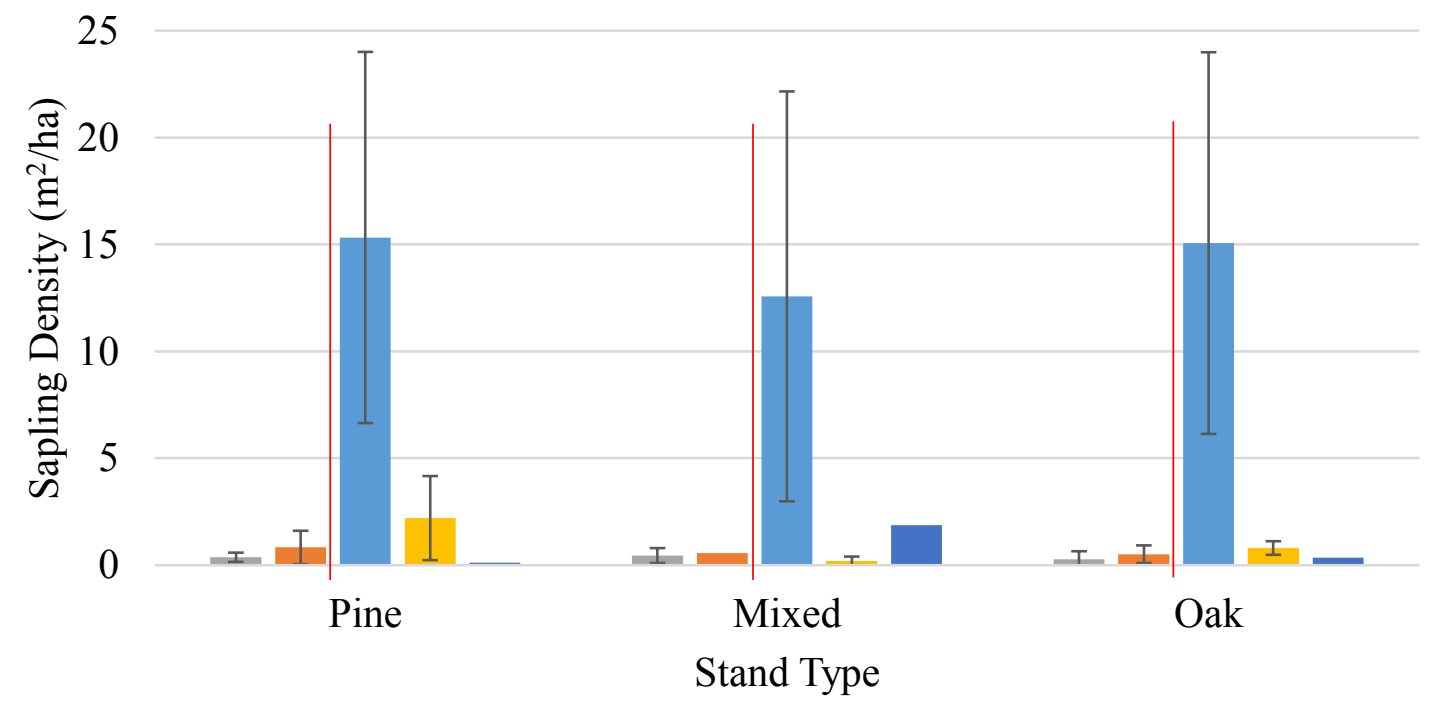

Figure 10. Sapling density by stand type and time sampled. 
However, Wang et al (2005), found that increases in seedling density were significantly related to decreased forest floor depth and increased understory light intensity, which suggests prescribed fires are having an indirect effect on seedlings. They also found that the effects of burning differed among stands, where significance of seedling density was related to fire behavior (i.e. severity). No significant effect of prescribed burning was found among stands where fire intensity remained low (Wang et al., 2005). Prescribed burns in Mark Twain National Forest are low severity burns, therefore it is possible that sites managed with prescribed burning are not significantly different than unburned sites for seedling/sapling densities.

\section{Soil Characteristics}

Leaf Litter and Duff Depths. Leaf litter and duff layer depths vary naturally among stands. Unburned mixed stand types tend to have the deepest litter and duff depths, followed by pine and oak stands (Figures 11 and 12). In general, burned sites have significantly less litter and duff depths than unburned sites $(p>0.05)$ (Table 8). During winter months burn sites on average have about 2-15 mm (10-30\%) less litter and 5-10 mm (10-40\%) less duff depth than unburned sites (Figures 11 and 12). During May, litter depth decreased by 20-30 mm (75-95\%) compared to sites burned more than a year ago (Figure 11). This decrease in litter depth is due to immediate effects of the prescribed burns in March 2016. Duff depths are higher in May following prescribed burning (20$30 \%$ ) compared to sites burned more than a year ago (Figure 12). This is likely due to the season sampled and time since leaf fall, where warmer temperatures promote

decomposition (Sierra et al., 2016). This indicates that prescribed burning was not severe 
enough to consume the duff layer. Other studies have found no significant effect of spring prescribed burns on duff depth, suggesting that remaining duff layers protect soils from erosion (Zabowski et al., 2007).

Sites that have been burned have significantly less duff depth than unburned sites (Table 8). During October 2016, both burned and unburned litter depths return to depths near those measured in December 2015 with 5-20 mm less litter (Figure 11). Similarly, duff depths measured in October 2016 nearly mirror depths measured in December 2015 for both burned and unburned sites, where differences are less than $5 \mathrm{~mm}$ (Figure 12).

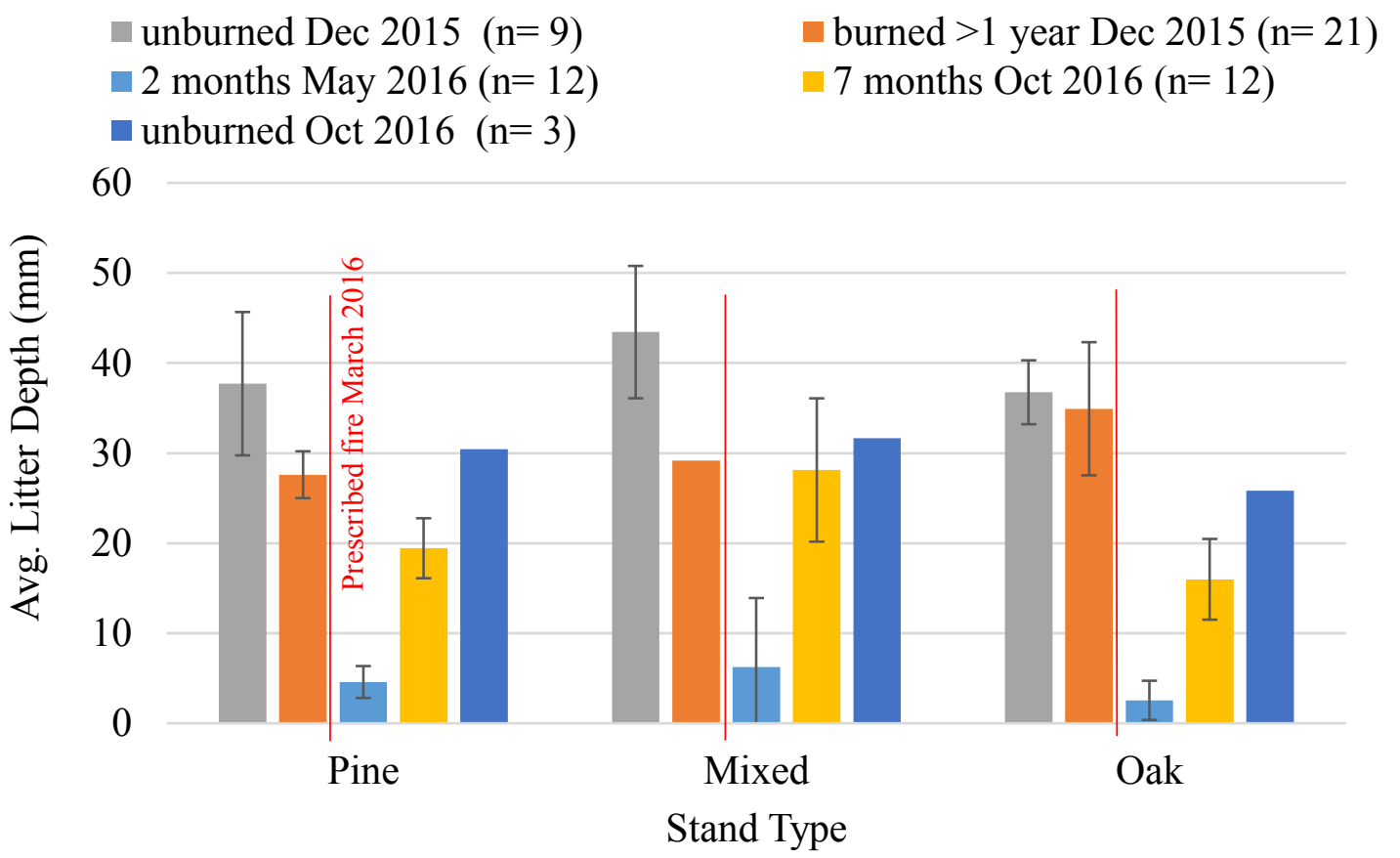

Figure 11. Litter depth by stand type and time sampled. 


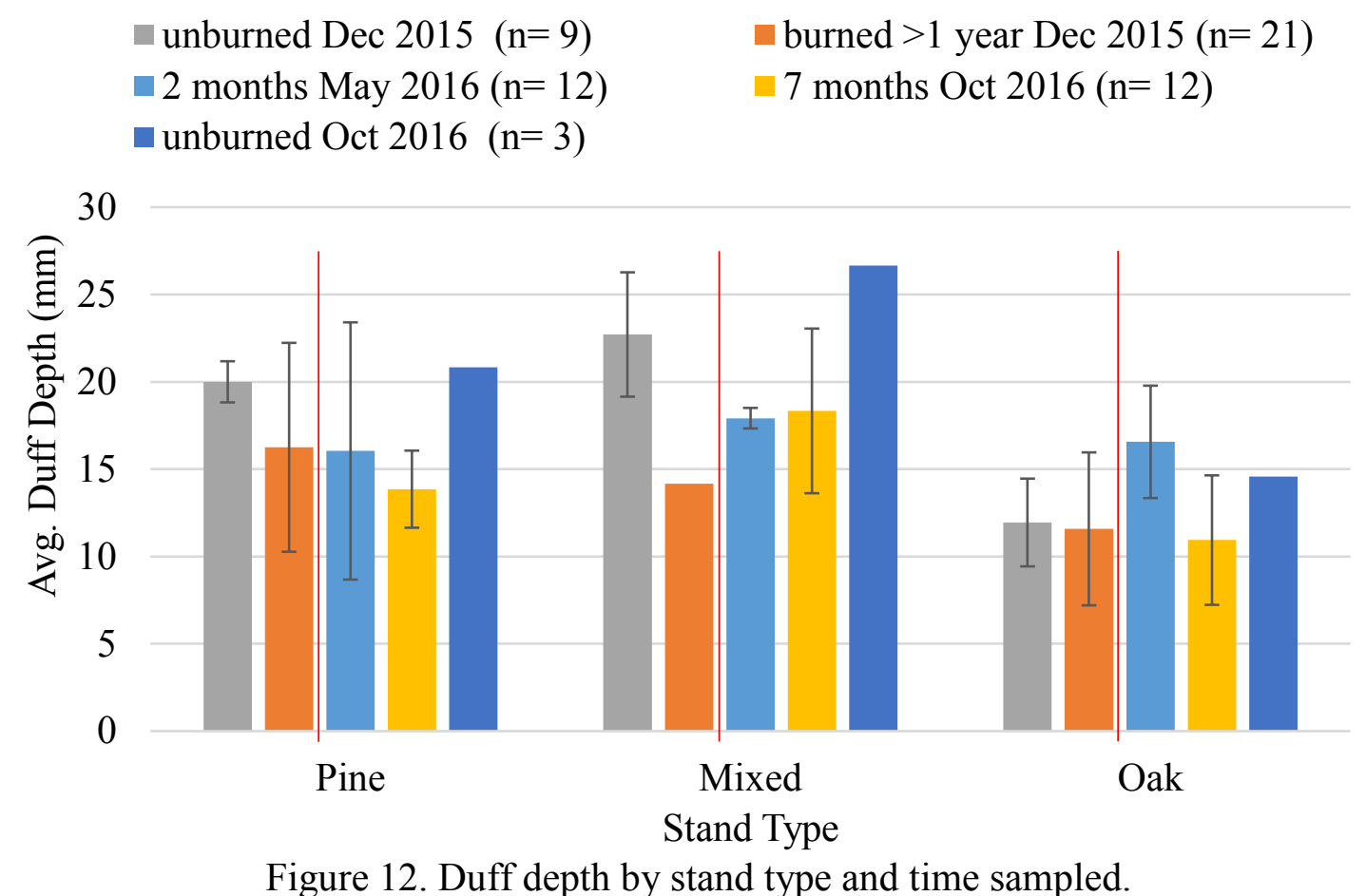

One-way ANOVA shows significant differences between burned and unburned sites and stand types for both litter depth and duff depth at the $95 \%$ confidence interval (C.I.) (Tables 8 and 9). While burned sites tend to have lower leaf litter depth and duff depths than unburned sites, litter and duff depths on burned sites appear to recover with similar depths to those measured at unburned sites over time, suggesting fires have a minimal long-term impact litter and duff depths. Kolaks et al. (2004), have similar findings for litter, where $50 \%$ of "equilibrium" litter accumulation returned within 2.5 years.

Soil Depth. One-way ANOVA was used to test the significance of prescribed fire on soil properties at $0-5 \mathrm{~cm}, 5-10 \mathrm{~cm}$, and $20-30 \mathrm{~cm}$ (subsoil) increments at the $95 \%$ C.I. There were statistically signficant differences between group means for burned and unburned sites at the 0-5 cm increment only (Table 8). Samples from 5-10 cm and 20-30 
cm show no statistical difference (Table 8). The same results were found for burned stand types (pine, oak, mixed) (Table 9). However, there were no significant differences between group means for unburned stand types at any of the depth increments. These results suggest that soil variability in general as well as potential prescribed fire effects are not altering soil properties below $5 \mathrm{~cm}$. Thus, only results for the $0-5 \mathrm{~cm}$ soil layer are evaluated below.

Organic Matter. Soil OM varies by stand as determined by the LOI method and is typically higher among pine stands followed by mixed and oak stands (Figure 13 and Table 9). Burned stands in general have significantly higher amounts of OM, about $20 \%$ more than unburned stands at the $95 \%$ C.I. (Figure 13 and Table 8). Organic matter is likely higher among burned stands because prescribed fires are not completely consuming either the litter layer or the duff layer (Zabowski et al., 2007) (Figures 13 and 14), nor is it significantly effecting CWD (Figure 13). However, CWD or decayed wood on the surface of forest floors can become charred during a prescribed fire, which adds additional OM to the soil (DeBano, 1991). Other studies have found increases in OM of the surface soil from frequent prescribed burns (2-5 years) (Wade and Lundsford, 1990; Patterson et al., 2004). 


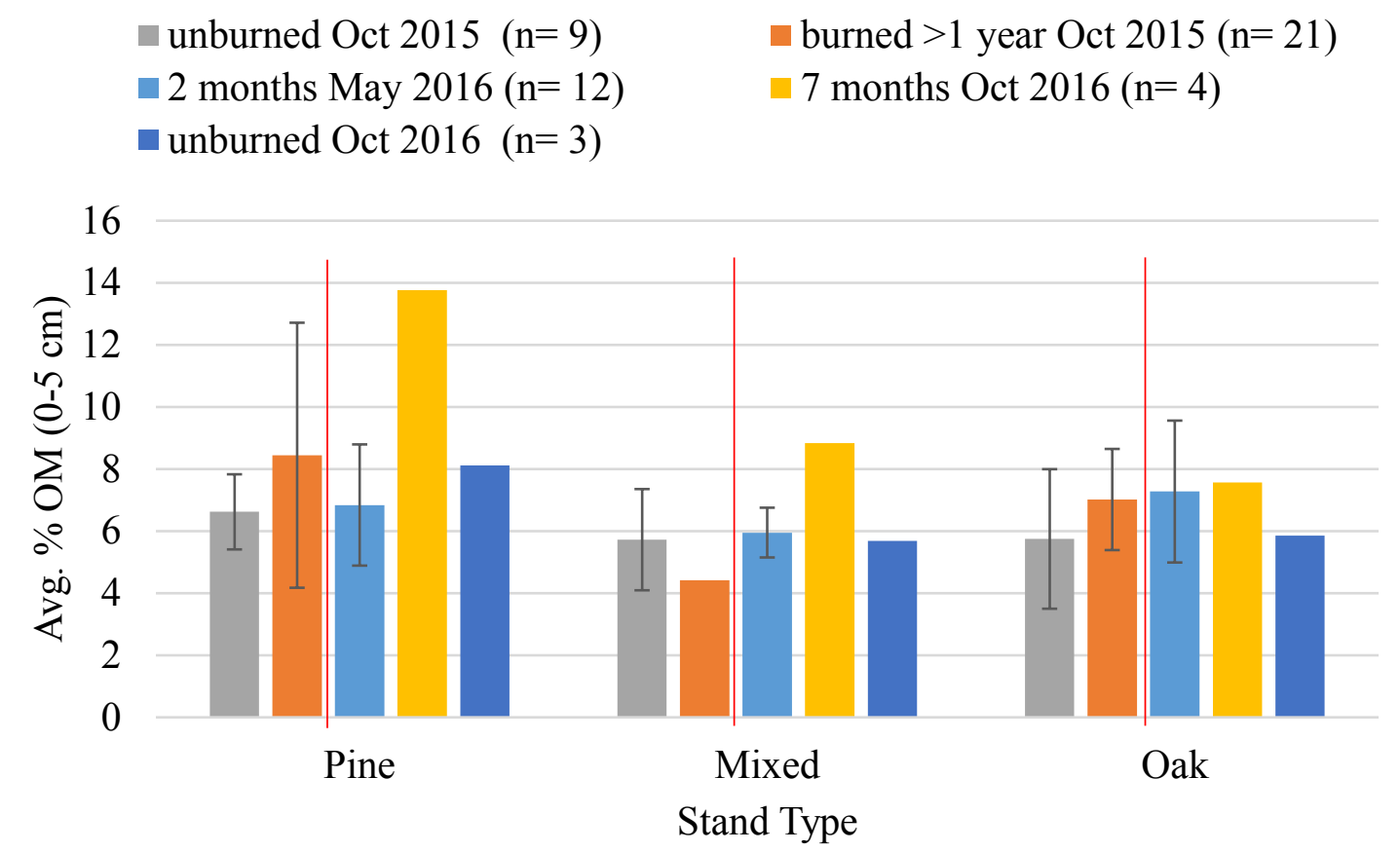

Figure 13. Percent organic matter by stand type and time sampled.

Bulk density. Soil BD is significantly different among burned and unburned stands, where burned stands have a lower BD than unburned stands, about 8-12\% (Figure 14 and Table 8). Burned stand types have significantly different bulk densities at the $95 \%$ C.I., while unburned stand types are not significantly different at the $95 \%$ C.I. (Table 9). Comparing the Figure 13 with figure 14, an inverse relationship appears, where OM is high, BD is typically lower. This relationship between OM content and BD has been found in other studies (Chaudhari et al., 2013). Organic matter improves aggregate stability, porosity and infiltration rates, therefore lowering BD (USDA-NRCS, 2008; USDA-NRCS 2015). 
unburned Oct $2015 \quad(\mathrm{n}=9)$

2 months May $2016(\mathrm{n}=12)$

unburned Oct $2016(\mathrm{n}=3)$ burned $>1$ year Oct $2015(\mathrm{n}=21)$

7 months Oct $2016(n=4)$

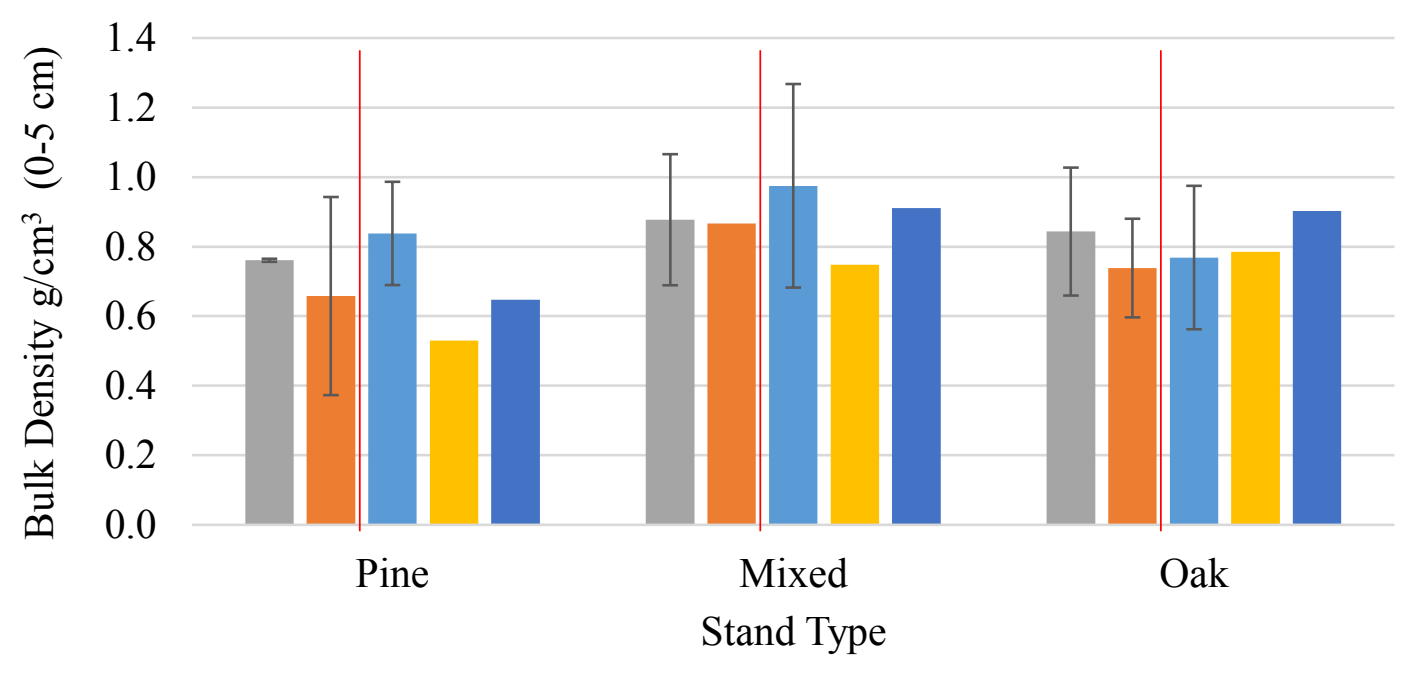

Figure 14. Bulk density by stand type and time sampled.

Grain Size. During this study, sites were located on one specific soil series so the soil type was effectively held constant. Hence, there were no statistically significant differences among group means for burned and unburned sites, nor among burned or unburned stand types (Figure 15 and Tables 8 and 9). Percent rock fragments $(>2 \mathrm{~mm})$ in the first $0-5 \mathrm{~cm}$ and $5-10 \mathrm{~cm}$ of the soil had a range of $3-45 \%$ and a median of $17.9 \%$ (Appendix I). Median diameter of soils $(<2 \mathrm{~mm})$ in burned oak stands is $66.3 \mu \mathrm{m}, 90.5$ $\mu \mathrm{m}$ for pine and $35.7 \mu \mathrm{m}$ for mixed stands (Tables 5-7). Median percent sand among stand types in the first $0-5 \mathrm{~cm}$ of the soil is $17.1 \mu \mathrm{m}$ for pine and oak stands, and 15.2 for mixed stands. Coefficient of variation of percent sand for each stand type was under $35 \%$. Therefore, prescribed fires do not effect grain size among burned and unburned sites. Differences in grain size, while not significant, are likely due to other factors such as weathering, geology, slope aspect and location in the watershed (Meinert et al., 1997). 


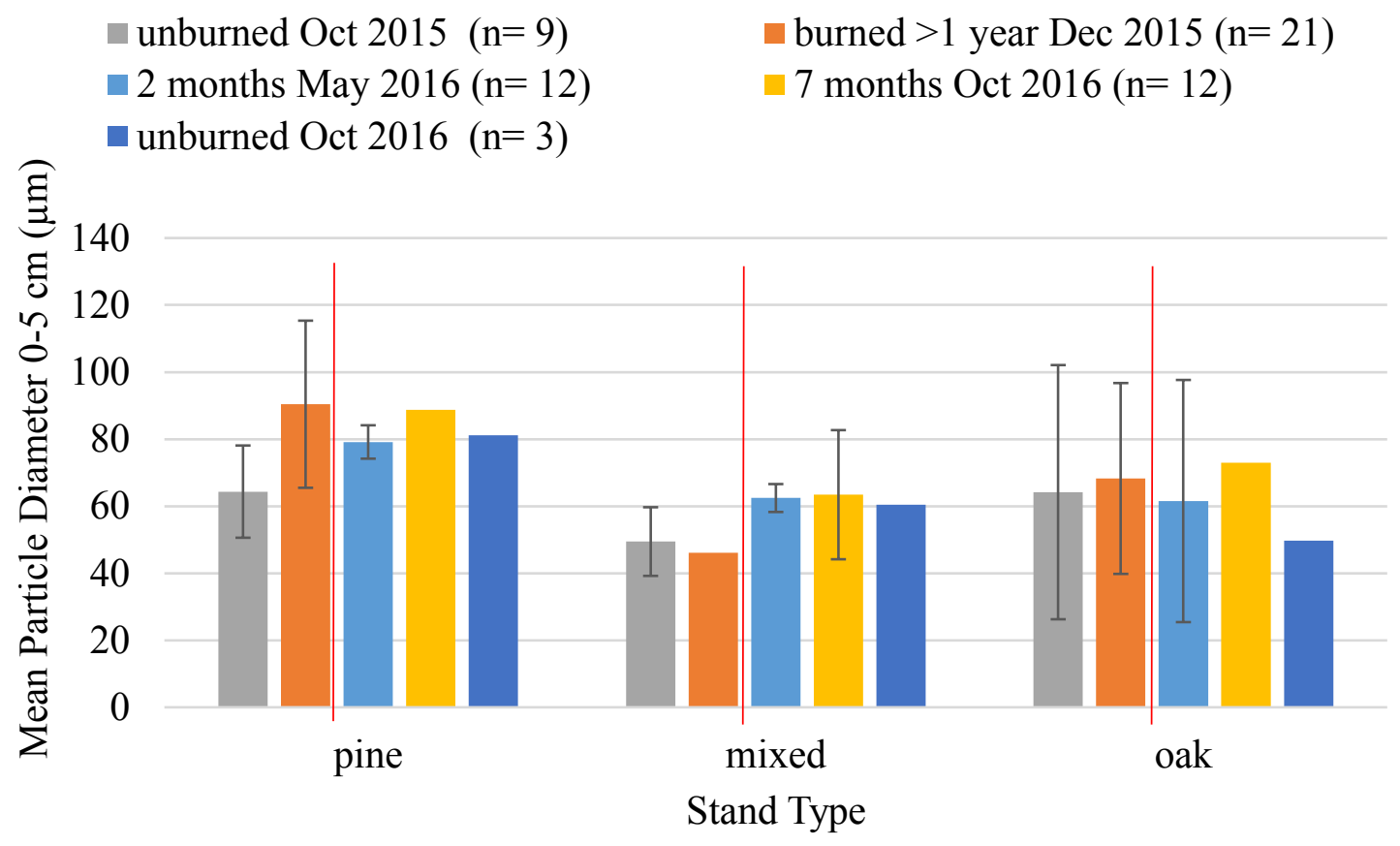

Figure 15. Mean particle diameter by stand type and time sampled.

\section{Recovery Trends}

While this study only began in October 2015, prescribed burning has been used in areas of the watershed since 2011 (Figure 4). Data were collected from unburned sites and burned sites of varying frequency (Appendix B). The purpose of this section is to evaluate recovery trends among burned and unburned site properties. This can be used to identify potential recovery periods for litter and duff depth, soil organic matter and bulk density.

Leaf Litter and Duff Depths. Short-term trends are observed following prescribed fires for up to 1-2 years (Figure 16). In May 2016, two months after burning, immediate effects of prescribed burning were apparent where litter decreased (Figures 11). Duff does not decrease in May following a burn. Instead, duff depth is higher, which as previously discussed indicates that prescribed burns are not severe enough to consume 
the duff layer (Zabowski et al., 2007). Additionally, litter depth begins to return to unburned depths by October 2016, seven months after a prescribed burn (Figure 16). Therefore, one seasonal leaf-off period can support recovery for litter. Litter and duff depths are easily recovered following prescribed burns as seasons progress (Figures 16 and 17).

Litter can fully recover within 2-4 years following a prescribed burn (Figure16). However, duff depth remains about $40 \%$ lower than unburned sites $2-4$ years after burning (Figure 17). Duff layer reduction observed in other studies was between $68.5 \%$ and $87.5 \%$ for fall prescribed burning (Gurbir et al., 2017). Fall burning can consume more litter and duff than spring burns, due to less moisture in the litter and duff layers or surface fuels (Zabowski et al., 2007).

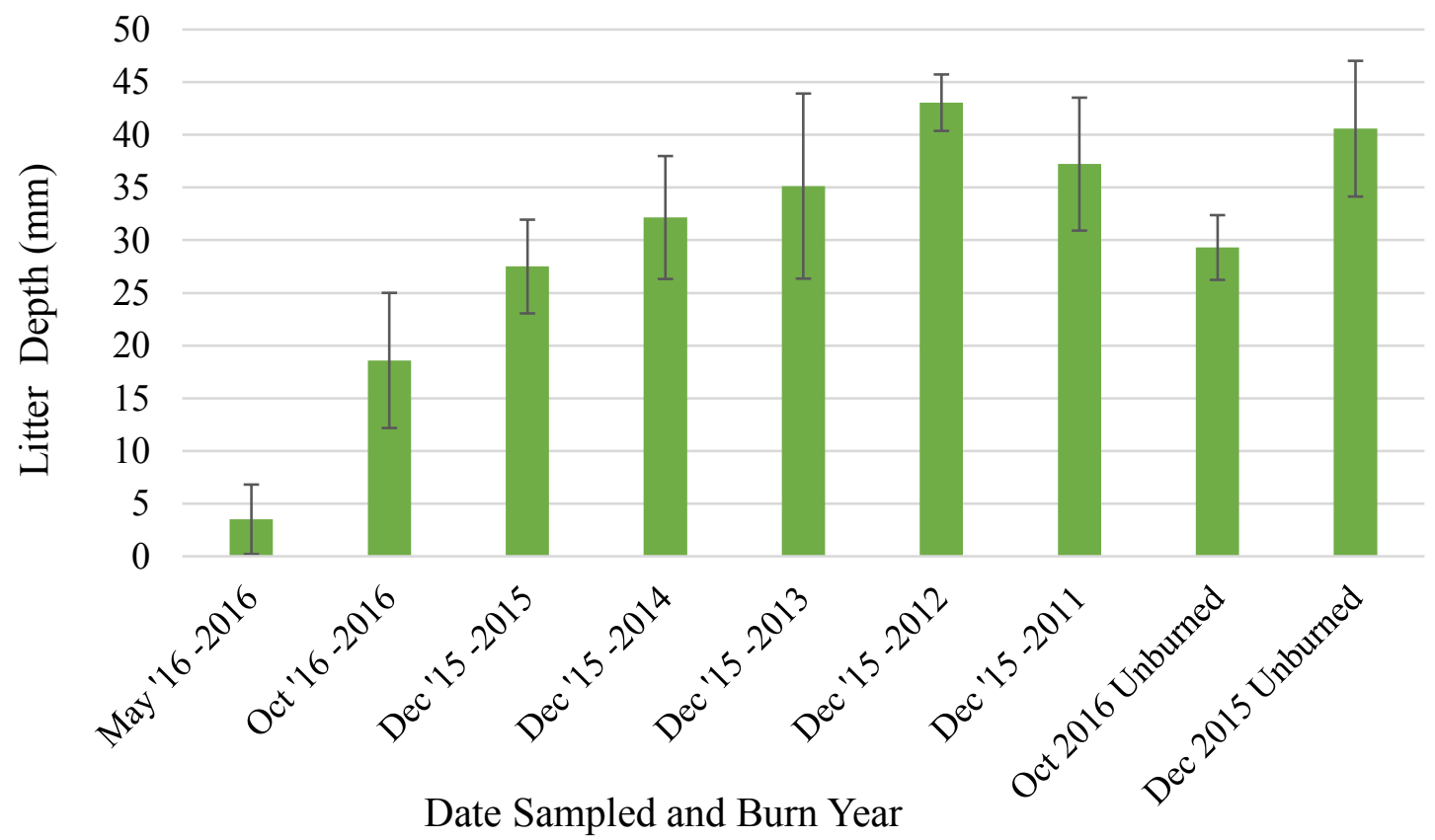

Figure 16. Litter depth measurements for date measured and last year burned. 


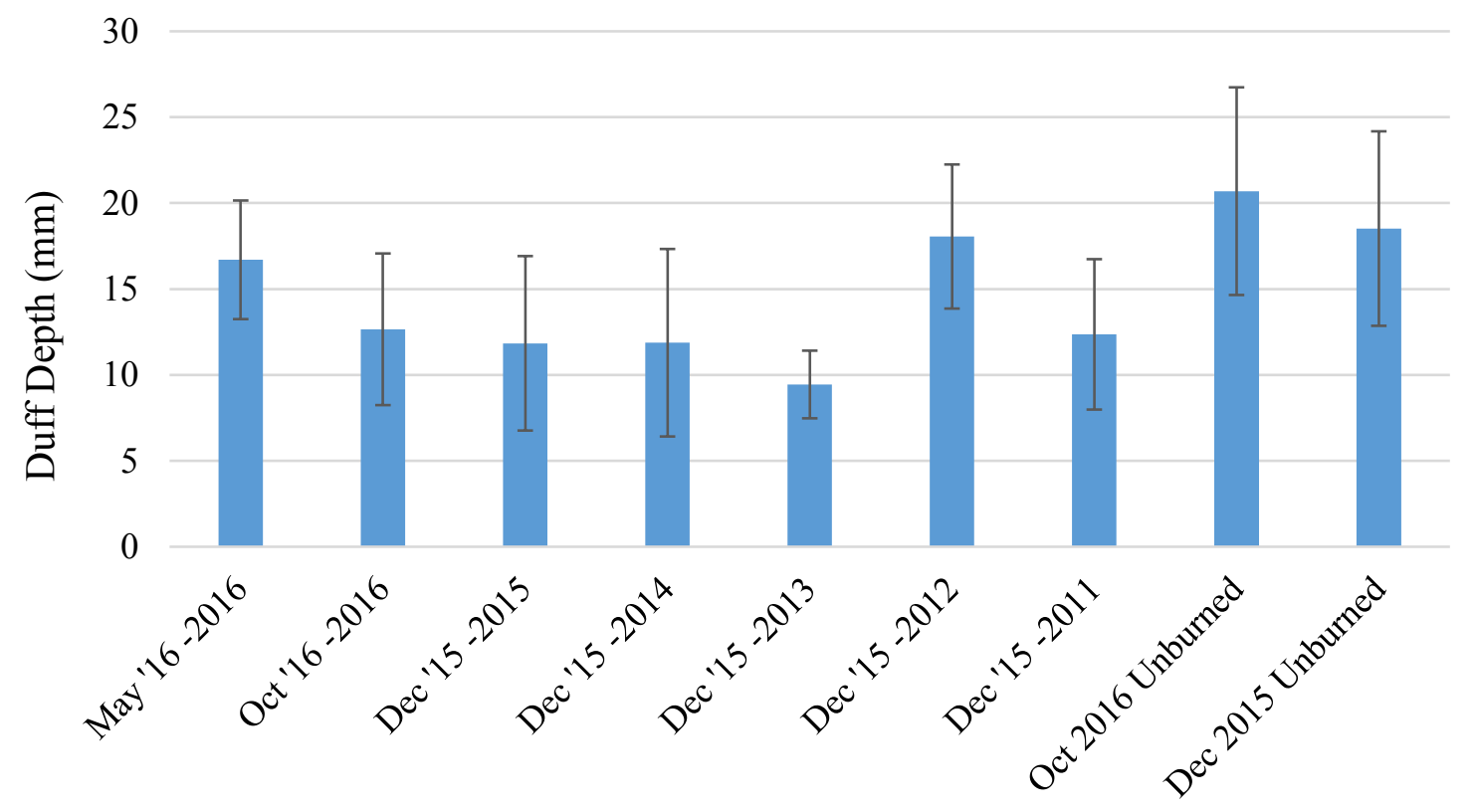

Date Sampled and Burn Year

Figure 17. Duff depth measurements for date measured and last year burned.

Organic Matter and Bulk Density. Organic matter tends to be 15-20\% higher among burned areas than unburned areas 1-2 years after prescribed burning (Figure 18). Figures 18 and 19 indicate that sites burned in 2012 and 2013 maintain about 40\% more $\mathrm{OM}$ and $23 \%$ less $\mathrm{BD}$ than unburned sites (Figure 18). On average, 2-4 years after burning, bulk density is about 19\% lower than unburned sites (Figure 19). In years where OM is higher, BD is lower (2012 and 2013), which displays an inverse relationship between soil OM and BD. This relationship was described by Chaudhari et al (2013) when investigating the dependence of BD on OM (Figures 18 and 19). Overall, soil OM is about $22 \%$ higher among burned sites, while bulk density is about $12 \%$ lower than unburned sites (Figures 18 and 19). These results suggest that prescribed burning enhances soil properties, where $\mathrm{OM}$ is increased and $\mathrm{BD}$ is decreased. 
Overall, litter depths are able to recover with one seasonal period. Duff appears to be unaffected by spring prescribed burning. Additionally, these recovery trends indicate that prescribed fire is enhancing soil physical properties (OM and BD) that improve soil aggregate stability and influence infiltration rates in the first 0-5 cm (Schoenholtz et al., 2000; USDA-NRCS, 2008). Relatively rapid recovery of ground cover coupled with these enhanced soil properties should promote healthy forest soils which increase surface roughness and infiltration rates and decrease runoff (Schoenholtz et al., 2000; USDANRCS, 2008).

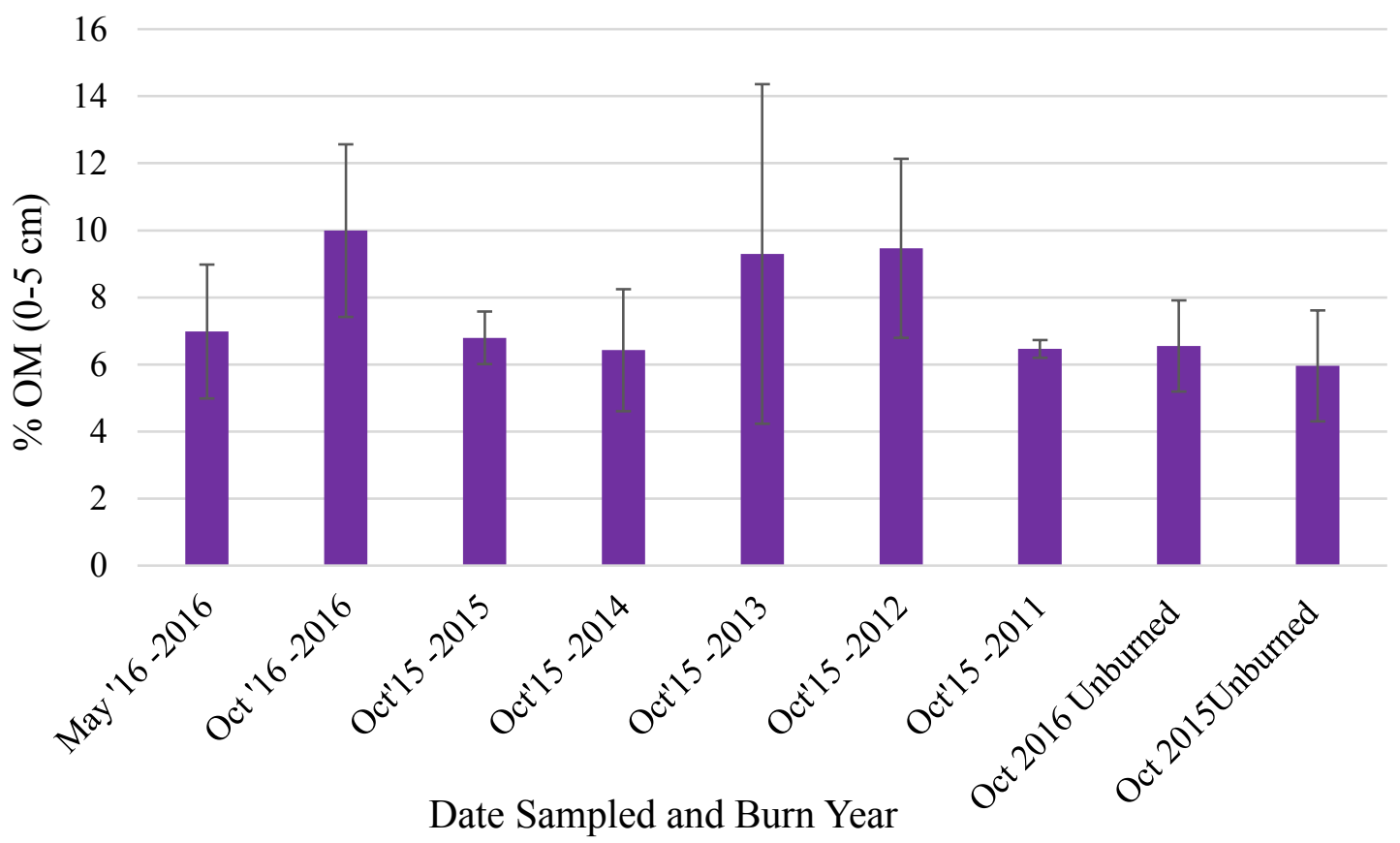

Figure 18. Percent organic matter measurements for date measured and last year burned. 


\section{2}

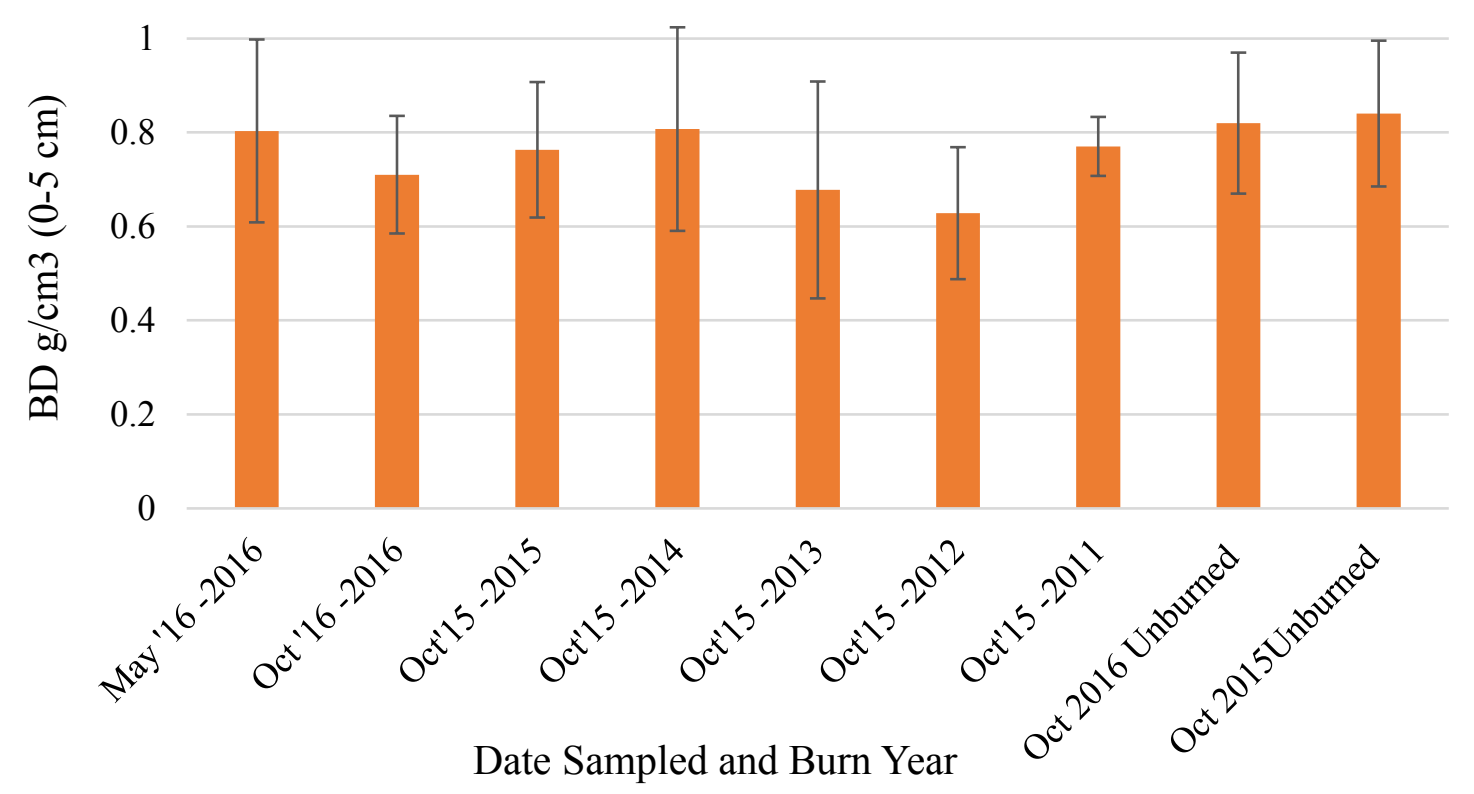

Figure 19. Bulk density measurements for date measured and last year burned.

\section{Universal Soil Loss Equation}

To further understand prescribed fire effects on forest conditions the Universal Soil Loss Equation (USLE) was used to calculate the average annual soil loss in metric tons/hectare/year $(A)$. Burned stand average annual soil loss per year $(A)$ was compared to unburned stands.

Unburned oak stands have an $A$ value of 0.15 metric tons/ha/year, whereas burned oak stands have an $A$ value of 0.16 metric tons/ha/year (Table 10). Similarly, unburned pine stands have an $A$ of 0.15 metric tons/ha/year and 0.18 metric tons/ha/year for burned pine stands (Table 10). These results are similar to other studies which have found that erosion from forests is virtually non-existent compared to croplands and grasslands (Raeker et al., 2011). The results of this model suggest that sites managed with prescribed burns have similar average annual soil losses per year as unburned sites. The nomograph 
for soil erodibility only reads up to $4 \% \mathrm{OM}$. Therefore the maximum amount of OM among burned and unburned sites used for this model was limited to $4 \%$. It is possible that average annual soil loss values $(A)$ could be even smaller given the higher amounts of percent OM measured among burned sites (Figures 9 and 10).

Table 10. Universal Soil Loss Equation Factors

\begin{tabular}{|c|c|c|c|c|c|c|c|c|c|}
\hline \multirow{2}{*}{ Site } & \multirow{2}{*}{\multicolumn{2}{|c|}{ Site Type }} & \multirow{2}{*}{$\mathrm{R}$} & \multirow{2}{*}{ K-f } & \multirow{2}{*}{ LS } & \multirow{2}{*}{$\mathrm{C}$} & \multirow{2}{*}{$\mathrm{P}$} & \multicolumn{2}{|c|}{ A } \\
\hline & & & & & & & & tons/acre & $\mathrm{Mg} / \mathrm{ha}$ \\
\hline 1 & Oak & Unburned & 177 & 0.19 & 0.5 & 0.004 & 1 & 0.067 & 0.15 \\
\hline 24 & Pine & Unburned & 177 & 0.19 & 0.5 & 0.004 & 1 & 0.067 & 0.15 \\
\hline 20 & Oak & Burned & 177 & 0.2 & 0.5 & 0.004 & 1 & 0.071 & 0.16 \\
\hline 18 & Pine & Burned & 177 & 0.23 & 0.5 & 0.004 & 1 & 0.081 & 0.18 \\
\hline
\end{tabular}

\section{Summary}

Sites that have been managed with prescribed burning have soil characteristics that are significantly different compared to unburned sites. Forest characteristics that are most influenced by prescribed burning are leaf litter depth, duff depth, soil OM, and BD. The effects of prescribed burning on these characteristics are positive, rather than negative. Leaf litter and duff depths are able to recover to pre-burn conditions within one season and make a full recovery 2-3 years following a prescribed burn.

Prescribed burning effects were only significant for the first $0-5 \mathrm{~cm}$ of the soil. Burned sites had significantly higher OM and lower BD than unburned sites which suggest prescribed burns enhance soil structure. There were no significant effects of burning on mean particle diameter or grain size, meaning the burns are not hot enough to alter grain size, and size distribution is more likely related to environmental factors. 
One question to be addressed by this study was to evaluate the influence of prescribed burning on erosion and subsequent water quality. The USLE was used to do this. The results suggest that prescribed burns may decrease annual rates of erosion compared to unburned sites. The two variables that most strongly influenced the equation for this study were the soil erodibility factor $(\mathrm{K})$ and the cover management $(\mathrm{C})$. Enhanced soil structure following prescribed burning along with maintained canopy cover promote soil stability and therefore reduce the risk for increased rates of erosion. Nevertheless, predicted soil erosion rates are relatively low and similar among both burned and unburned sites. Therefore, it is expected that runoff and eroded sediment from burned areas should not affect water quality to a level beyond unburned forest conditions. 


\section{CHAPTER 5 - CONCLUSIONS}

Pine regeneration among Missouri forests is important not only for habitat creation and restoration, but also for economic purposes such as logging. Prescribed burns are being used to help restore forests in Mark Twain National Forest to their original shortleaf pine-oak stands (USDA-FS, 2012). A mixture of silviculture and prescribed burning are extremely important for pine regeneration (Guyette et al., 2007). There are concerns over the effects of prescribed burning on water quality from both residents and local agencies. The combination of field, laboratory and statistical methods helped to assess the effects of prescribed fires on forest and soil characteristics that control hydrologic processes. There are 4 key findings of this study:

1. Leaf litter and duff depths, soil $O M$ and $B D$ at $0-5 \mathrm{~cm}$ on sites managed with prescribed fire were significantly different compared to unburned sites. Leaf litter and duff depths were significantly lower among burned stands (Table 8) (Figures 11 and 12). Burned sites had about 10-30\% less litter in winter and 7595\% less litter two months after a prescribed burn (Figure 11). However, one seasonal leaf-off period can provide for recovery of litter. There was about $10-$ $40 \%$ less duff in winter months and this trend continued up to 4 years after prescribed burning (Figures 12 and 17). Burned stands had a higher percent of OM $(22 \%)$ and lower BD $(12 \%)$ than unburned stands in the first $0-5 \mathrm{~cm}$ of the soil (Figures 18 and 19). Recovery of ground cover within a year coupled with increased $\mathrm{OM}$ and decreased BD enhances soil structure and porosity and thus infiltration rates, thereby reducing the risk of runoff and erosion (Li et al., 2014; USDA-NRCS, 2008).

2. Prescribed burns did not significantly effect soil grain size, OM or BD below $5 \mathbf{c m}$. Prescribed burning did not significantly alter grain size within the top 30 $\mathrm{cm}$ of soil depth (Tables 8 and 9). Additionally, prescribed burns do not cause significant differences among soil properties that influence infiltration below $5 \mathrm{~cm}$ of the soil, which indicates that the spring prescribed burns applied in Mark Twain National forest are not severe enough to alter subsoil properties (Tables 8 and 9) (Zabowski et al., 2007). 
3. Prescribed fires typically have little effect on, or may even enhance, forest soil characteristics which control infiltration rates and reduce runoff. Leaf litter recovers to unburned conditions within a year as seasonal biomass influx occurs (Figure 11 and 16). Duff depths recover within about 2-4 years following a prescribed burn (Figure 17). Organic matter in burned sites soil was about $22 \%$ higher than unburned sites (Figure 18). Bulk density was about 12\% lower among burned sites compared to unburned sites (Figure 19). There are no clear recovery trends for $\mathrm{OM}$ and $\mathrm{BD}$, however about 2-3 years after burning $\mathrm{OM}$ was the highest and BD was the lowest.

4. Universal Soil Loss Equation analysis indicates that sites managed with prescribed burning have similar average annual soil loss rates in $\mathrm{Mg} / \mathrm{ha} / \mathrm{year}$ compared to unburned sites. Unburned pine and oak stands had the same predicted average annual soil loss rate of 0.15 metric tons $/$ ha/year. Burned pine stands had a slightly higher predicted soil loss rate of 0.18 metric tons/ha/year compared to 0.16 metric tons/ha/year for burned oak stands. These erosion rates are similar to those measured in other forested lands (Raeker et al., 2011). Therefore, prescribed burning has little effect on runoff and soil erosion on level upland locations within Mark Twain National Forest.

\section{Future Work}

While this study found that prescribed burning on uplands is not negatively effecting soil characteristics which control hydrologic processes, more research is needed to understand how/if prescribed burns effect soil conditions and subsequent runoff on hillslopes and riparian areas. Field tests would be the most accurate way to collect data and assess sediment loading following prescribed burning. Continual monitoring of the sites throughout the Big Barren watershed should be implemented to better understand the long-term effects of prescribed burning on forest, soil and watershed conditions. 


\section{REFERENCES}

Adamski, J.C., Petersen, J.C., Freiwald, D.A., Davis, J.V., 1995. Environmental and hydrologic setting of the Ozark Plateau study unit, Arkansas, Kansas, Missouri, and Oklahoma. U.S. Geological Survey. Water-Resources Investigations Report 94-4022.

Bendix, J., and Cowell, C.M., 2010, Impacts of wildfire on the composition and structure of riparian forests in southern California: Ecosystems, 13: 99-107.

Blizzard, E.M., Henken, D., Kabrick, J.M., Dey, D.C., Larsen, D.R., and Gwaze D., 2007, Shortleaf pine reproduction abundance and growth in pine-oak stands in the Missouri Ozarks: Proceedings of Shortleaf pine restoration and ecology in the Ozarks: U.S. Department of Agriculture, Forest Service, Northern Research Station, p. 138-146.

Carter, M.C., and Foster, D.C., 2003, Prescribed burning and productivity in southern pine forests: A review: Forest Ecology and Management, 191 (2004) p. 93-109.

Certini, G., 2005, Effects of fire on properties of forest soils: A review: Oecologia 143:110 .

Chaudhari, P.R., Ahire, D.V., Ahire, V.D., Chkravarty, M., and Maity, S., 2013, Soil bulk density as related to soil texture, organic matter content and available total nutrients of Coimbatore soil: International Journal of Scientific and Research Publications, v. 3, Issue 2, ISSN: 2250-3153.

Covert, S.A., Robichaud, P.R., Elliot, W.J., and Link, T.E., 2005, Evaluation of runoff Prediction from WEPP-Based erosion models for harvested and burned forest watersheds: Transactions of the ASAE 48, p. 1091-1100.

Cunningham, R.J., 2007, Historical and social factors affecting pine management in the " Ozarks during the late 1800's through 1940: Proceedings of Shortleaf pine restoration and ecology in the Ozarks: U.S. Department of Agriculture, Forest Service, Northern Research Station, p. 1-6.

Davis, T.R., 2006, Soil phosphorus levels in residential lawns and comparisons among four land uses in Springfield, Missouri, [M.S. Thesis]: Missouri State University, p. 12.

DeBano, L.F., 1991, The effect of fire on soil properties: Proceedings-management and productivity of western-montane forest soils: U.S. Department of Agriculture, Forest Service, Intermountain Research Station, p. 151-156. 
Elliot, K.J., and Vose, J.M., 2006, Fire effects on water quality: A synthesis of response regulation factors among contrasting ecosystems: Proceedings of the Second Interagency Conference on research in the Watersheds, May 16-18, p.77-87.

Environmental Protection Agency (EPA), Rainfall erosivity factor calculator for small construction sites, 2017: https://www.epa.gov/npdes/rainfall-erosivity-factorcalculator-small-construction-sites\#getTool (accessed March 2017).

Eshel, G., Levy, G.J., Mingelgrin, U., and Singer, M.J., 2004, Critical evaluation of the use of laser diffraction for particle-size distribution analysis: Soil Science Society of America Journal, v. 68, p. 736-734.

Fisher, R.F.; Binkley, D., 2000, Ecology and Management of Forest Soils, 3rd Ed: New York: John Wiley and Sons, Inc. p. 489.

Follett, R.F., 1995, Fate and transport of nutrients: Nitrogen: USDA, Agricultural Research Service Soil-Plant-Nutrient Research Unit Fort Collins, Colorado: http://www.nrcs.usda.gov/wps/portal/nrcs/detail/national/landuse/crops/?cid=nrcs 143014202 (accessed October 2015).

Forest Inventory and Analysis National Core Field Guide (FIA), 2014: Field data collection procedures for phase 2 plots, Version 6.1, v.1: http://www.fia.fs.fed.us/library/field-guides-methods-proc/ (accessed October 2015).

Forest Inventory and Analysis National Core Field Guide (FIA), 2011: Soil measurements and sampling- phase 3, Version 5.1, p. 1-31: https://www.fia.fs.fed.us/library/field-guides-methodsproc/docs/2012/field_guide_p3 5-1_sec22_10_2011.pdf (accessed September 2015).

Gingrich, S.F., 1967, Measuring and evaluating stock and stand density in upland hardwood forests in the central states: Forest Science, v. 13, No. 1, p. 38-53.

Graham, R.T., McCaffrey, S., Jain, T.B., 2004, Science basis for changing forest structure to modify wildfire behavior and severity: Department of Agriculture, Forest Service, Rocky Mountain Research Station, p. 43.

Gray, R., Kobizar, L., Riley, K., Ryan, K., Godwin, D., Robertson, K., Ingalsbee, T., Prusak, Z., and Huffman, M., 2013, The Merits of Prescribed Fire Outweigh Potential Carbon Emission Effect: Association for Fire Ecology, International Association of Wildland Fire, Tall Timbers Research Station, The Nature Conservancy, p. 1-8.

Gray, D.H., and Leiser, A.T., 1982, Biotechnical slope protection and erosion control: New York, Van Nostrand Reinhold Company. 
Gurbir, S., Schoonover, J.E., Monroe, K.S., Williard, K.W.J., and Ruffner, C.M., 2017, Prescribed burning and erosion potential in mixed hardwoods forests of southern Illinois: Forests, v. 8, doi:10.3390/f8040112, p. 1-20.

Guyette, R.P., Muzika, R., Voelker, S.L., 2007, The historical ecology of fire, climate, and the decline of shortleaf pine in the Missouri Ozarks: Proceedings of the Missouri Ozark Forest Ecosystem Project: Site history, soils, landforms, woody and herbaceous vegetation, down wood, and inventory methods for the landscape experiment: Department of Agriculture, Forest Service, North Central Research Station, p. 19-23.

Guyette, R., and Larsen, D., 2000, A history of anthropogenic and natural disturbances in the area of the Missouri Ozark forest ecosystem project: Proceedings of the Missouri Ozark Forest Ecosystem Project: Site history, soils, landforms, woody and herbaceous vegetation, down wood, and inventory methods for the landscape experiment: Department of Agriculture, Forest Service, North Central Research Station, p. 19-23.

Gwaze, D., Melick, R., McClure, L., Studyvin, C., Massengele, D., 2007, Effects of site preparation subsoiling and prescribed burning on survival and growth of shortleaf pine in the Mark Twain National Forest: Results after 20 growing seasons: Proceedings of Shortleaf pine restoration and ecology in the Ozarks: Department of Agriculture, Forest Service, Northern Research Station, p. 129-133.

Hamman, S.T., Burke, I.C., and Knapp, E.E., 2008, Soil nutrients and microbial activity after early and late season prescribed burns in a Sierra Nevada mixed conifer forest: Forest Ecology and Management, v. 256, p. 367-374.

Hamza, M.A., Anderson, W.K., Soil compaction in cropping systems: A review of the nature, causes and possible solutions: Soil and Tillage Research, v. 82, p. 121145.

Henely, W.F., Patterson, M.A., Neves, R.J., and Lemly, A.D., 2000, Effects of sedimentation and turbidity on lotic food webs: A concise review for natural resource managers: Reviews in Fisheries Science, v. 8, p. 125-139.

Jandl, R., Linder, M., Vesterdal, L., Bauwens, B., Baritz, R., Hagedorn, F., Johnson, D.W., Minkkinen, K., and Byrne, K.A., 2004, How strongly can forest management influence soil carbon sequestration?: Geoderma v.137, p. 253-268.

Kabrick, J., Meinert, D., Nigh, T., and Gorlinsky, B.J., 2000, Physical environment of the Missouri Ozark forest ecosystems project sites: Proceedings of the Missouri Ozark Forest Ecosystem Project: Site history, soils, landforms, woody and herbaceous vegetation, down wood, and inventory methods for the landscape experiment: Department of Agriculture, Forest Service, North Central Research Station, p. 41-70. 
Knapp, B.O., Stephan, K., and Hubbart, J.A., 2015, Structure and composition of an oakhickory forest after 60 years of repeated prescribed burning in Missouri, U.S.A: Forest Ecology and Management, v. 344, p. 95-109.

Kolaks, J.J., Cutter, B.E., Lowenstein, E.F., Grabner, K.W., Hartman, G.W., and Kabrick, J.M., 2004, The effect of thinning and prescribed fire on fuel loading in the central hardwood region of Missouri: Proceedings, $14^{\text {th }}$ Central Hardwood Conference: Newton Square, PA: U.S. Department of Agriculture, Forest Service, Northeastern Research Station, p. 168-178.

Ladd, D., Heumann, B., and Nelson, P., 2007, The Pineknot project: Restoration of a Missouri Ozark pinery: Proceedings of Shortleaf pine restoration and ecology in the Ozarks: U.S. Department of Agriculture, Forest Service, Northern Research Station, p. 204-205.

Li, X., Niu, J., and Xie, B., The effect of leaf litter cover on surface runoff and soil in Northern China, 2014:

http://journals.plos.org/plosone/article?id=10.1371/journal.pone.0107789 (accessed December 2015).

Loch, R.J., 2000, Effects of vegetation cover on runoff and erosion under simulated rain and overland flow on a rehabilitated site on the Meandu Mine, Tarong, Queensland: Australian Journal of Soil Research v. 38, p. 299 - 312.

Massman, W.J., Frank, J.M., 2006, Effects of controlled burns on the bulk density and thermal conductivity of soils at a southern Colorado site. In: 27th Conference on Agricultural and Forest Meteorology: American Meteorological Society: https://ams.confex.com/ams/pdfpapers/110226.pdf (accessed December 2015).

McCaffrey, S.M., 2006, Prescribed fire: What influences public approval?: Proceedings of Fire in Eastern Oak Forests, Delivering Science to Land Managers: USDA Forest Service, p. 192-198.

McLaren, P., and Bowles, D., 1985, The effects of sediment transport on grain-size Distributions: Journal of Sedimentary Petrology, v. 55, No. 4, p. 457-470.

Meinert, D., Nigh, T., Kabrick, J., 1997, Landforms, geology and soils of the MOFEP study area: Proceedings of the Missouri Ozark Forest Ecosystem Project symposium: An experimental approach to landscape research: Department of Agriculture, Forest Service, North Central Forest Experiment Station, p. 56-68

Menashe, E., 1998, Vegetation and Erosion- A literature Survey: Proceedings, Conference at Oregon State University, Native Plants: Propagation and Planting: Forest Research Laboratory, p. 130-135 
Missouri Department of Natural Resources (MDNR), 1986, Missouri Water Atlas: Missouri Department of Natural Resources, Jefferson City, Missouri.

Natural Resources Conservation Service (NRCS), 2017, Missouri field office technical guide- Section 1, C factor tables: https://efotg.sc.egov.usda.gov/references/public/MO/Table_2a rev.pdf (accessed April 2017).

Nave, L.E., Vance, E.D., Swanston, C.W., and Curtis, P.S., 2010, Fire effects on temperate forest soil C and N storage: Ecological Society of America v. 21, p. 1189-1201.

Neary, D.G., Ryan, K.D., DeBano, L.F., Landserber, J.D., and Brown, J.K., 2005, Wildland fire in ecosystems: Effects of fire on soil and water: USDA Forest Service, Rocky Mountain Research Station, p.7.

Nigh, T.A., 2007, The Ozark highlands pine-oak woodland restoration partnership: Proceedings of Shortleaf pine restoration and ecology in the Ozarks: Department of Agriculture, Forest Service, Northern Research Station, p. 214-215.

Ornoff, R.C., Weary, D.J., and Sebela, S., 2001, Geologic frame work of the Ozarks of South- Central Missouri- contributions to a conceptual model of Karst: U.S. Geological Survey Karst Interest Group Proceedings, Water-Resources Investigations Report 01-4011, p. 18-24.

Ottmar, R., Andreu, A., 2007, Litter and duff bulk densities in the southern United States: final report for Joint Fire Sciences Program, Project 04-2-1-49. Pacific Northwest Research Station, Seattle, WA.

Ozarks Environmental and Water Resources Institute (OEWRI), 2007, Standard operating procedure: Organic matter in sediment, loss on ignition method, Missouri State University.

Ozarks Environmental and Water Resources Institute (OEWRI), 2008, Standard operating procedure: LS 13320 Laser Diffraction Particle Size Analyzer operation, Missouri State University

Patterson, W.B., Sword-Sayer, M.A., Haywood, J.D., and Brooker, S., 2004, Effects of vegetation management with prescribed fire on soil physical properties in a young longleaf pine stand: Department of Agriculture, Forest Service, Southern Research Station, p. 74-78.

Phillips, M.J., Swift, L.W. Jr., and Blinn, D.R., 2000, Best management practices for riparian areas: Riparian management in forests of the continental eastern United States, Boca Raton, FL, Lewis Publishers, CRC Press LLC, p. 273-286. 
Raeker, G., Moser, K.W., Butler, B.J., Fleming, J., Gormanson, D.D., Hansen, M.H., Kurtz, C.M., Miles, P.D., Morris, M., Treiman, T.B., 2011, Missouri’s forests 2008: Resource Bulletin NRS-54: U.S. Department of Agriculture, Forest Service, Northern Research Station, p. 1-64.

Reardon, J.R., Ryan, K.C., DeBano, L.F., and Neary, D.G., 2005, Wetlands and riparian Systems: Proceedings of Wildland fire in ecosytems: Effects of fire on soil and water: USDA Forest Service, Rocky Mountain Research Station, p. 149-169

Reilly, M.J., Outcalt, K., O’Brien, J.J., and Wade, D., 2016, Effects of repeated growing season prescribed fire on the structure and composition of pine-hardwood forests in the southeastern Piedmont, USA: Forests, v. 8, p. 1-12, doi:10.3390/f8010008.

Reitz, R., and Gwaze, D., 2010, Landowner attitudes towards shortleaf pine restoration: Science and Management Technical Series: Number 2: Missouri Department of Natural Resources, Jefferson City, Missouri, p. 1-20.

Renard, K.G., Yoder, D.C., Lightle, D.T., and Dabney, S.M., 2010, Universal soil loss equation and revised universal soil loss equation: Handbook of Erosion Modeling, v.1, p.137-167.

Rogerson, P.A., 2014. Statistical Methods for Geography: A Student's Guide, Fourth Edition. Sage Publications Ltd, p. 177-198.

Schoenholtz, S.H., Miegroet, H.V., and Burger, J.A., 2000, A review of chemical and physical soil properties as indicators of forest soil quality: Challenges and Opportunities: Forest Ecology and Management, v. 138, p. 335-356.

Sierra, C.A., Malghani, S., and Loescher, H.W., 2016, Interactions among temperature, moisture and oxygen concentrations in controlling decomposition rates in a boreal forest soil: Biogeosciences, v. 14, p. 703-710.

Sikkink, P.G., Lutes, D.E., and Kean, R.E., 2009, Field Guide for identifying fuel loading Models: USDA Forest Service, Rocky Mountain Research Station, p. 2-3.

Sparks, D.L.,1996, Methods of Soil Analysis: Chemical Methods: Soil Science Society of America, Inc., Series 5, Part 3.

Stattrek, http://stattrek.com/statistics/random-number-generator.aspx (accessed September 2015).

Tiedemann, A.R., Klemmedson, J.O., and Bull, E.L., 1998, Solution of forest health problems with prescribed fire: Are forest productivity and wildlife at risk?: Forest Ecology and Management, v. 127, p. 1-18. 
United States Department of Agriculture- Forest Service (USDA-FS), 2012, Forest's Collaborative forest landscape restoration project 2012-2022:

https://www.fs.usda.gov/detail/mtnf/landmanagement/?cid=stelprdb5423048 accessed October 2015).

United States Department of Agriculture- Forest Service (USDA-FS), 2017a, FSGeodata Clearinghouse: https://data.fs.usda.gov/geodata/ (accessed October 2016).

United States Department of Agriculture- Forest Service (USDA-FS), 2017b, Restoration Glossary: https://www.fs.fed.us/restoration/reforestation/glossary.shtml (accessed March 2017).

United States Department of Agriculture (USDA) Kellogg Soil Survey, 2014, Laboratory Methods Soil Survey Investigations Report No. 42 v. 5, p. 276-281.

United States Department of Agriculture- National Cooperative Soil Survey (USDANCSS), 2005, Official series description- Macedonia

Series: https://soilseries.sc.egov.usda.gov/OSD Docs/M/MACEDONIA.html (accessed September 2015).

United States Department of Agriculture- Natural Resources Conservation Service (USDA-NRCS), 2004, 3.3 Bulk Density- Measurements: https://www.nrcs.usda.gov/Internet/FSE DOCUMENTS/nrcs142p2 051670.pdf (accessed December 2015).

United States Department of Agriculture- Natural Resources Conservation Service (USDA-NRCS), 2017, Geospatial Data Gateway: https://gdg.sc.egov.usda.gov/GDGOrder.aspx (accessed September 2015).

United States Department of Agriculture- Natural Resources Conservation Service (USDA-NRCS), 2015, Role of soil organic matter: http://www.nrcs.usda.gov/wps/portal/nrcs/detailfull/soils/health/mgnt/?cid=nrcs14 2p2_053859 (accessed October 2015).

United States Department of Agriculture- Natural Resources Conservation Service (USDA-NRCS), 2008, Soil quality indicators: http://www.nrcs.usda.gov/Internet/FSE_DOCUMENTS/nrcs142p2_053256.pdf (accessed October 2015).

United States Department of Agriculture- Natural Resources Conservation Service, Web Soil Survey (USDA-WSS), 2017:

https://websoilsurvey.sc.egov.usda.gov/App/WebSoilSurvey.aspx (accessed March 2017).

United States Forest Service- Forest Service Manual (USFS-FSM), 2014, Silvicultural Practices: Forest Management: Washington, DC, p. 10-12. 
Vana-Miller, D.L., 2007, Water resources foundation report: Ozark National Scenic Riverways, Natural Resources Report NPS/NRWRD/NRR: National Park Service, Water Resources Division, Fort Collins, Colorado, p. 1-46.

Wade, D.D., and Lundsford, J., 1990, Fire as a forest management tool: Prescribed burning in the southern united states: Food and Agriculture Organization of the United Nations: http://www.fao.org/docrep/t9500e/t9500e07.htm (accessed December 2016).

Wang, G.G., Van Lear, D.H., Bauerle, W.L., 2005, Effects of prescribed fires on firstyear establishment of white oak seedlings in the Upper Piedmont of South Carolina, USA: Forest Ecology and Management, v. 213, p. 328-337.

Ward, A.D., and Trimble, S.W., 2004, Environmental Hydrology, $2^{\text {nd }}$ edition: Florida, CRC Press LLC, p. 259-268.

White, C.S., Pendleton, R.L., Pendleton, B.K., 2006, Response of two semiarid grasslands to a second fire application: Rangeland Ecology and Management, v. 59, p. $98-106$

Winter, G., Vogt, C., and McCaffrey, S.M., 2005, Community views of fuel management: Are national forest local recreation users more supportive?: Survey data report, prepared for North Central Research Station: USDA Forest Service, p. 546-550.

Wischmeier, W.H., and Smith, D.D., 1965, Predicting rainfall-erosion losses from cropland east of the Rocky Mountains: a guide for selecting practices for soil and water conservation: USDA Agricultural Handbook, No. 282:

https://naldc.nal.usda.gov/download/CAT87208342/PDF (accessed March 2017).

Woodall, C.W., and Monleon, V.J., 2008, Sampling protocol, estimation, and analysis procedures for the down woody materials indicator of the FIA program: United States Department of Agriculture, Forest Service and National Research Station, p. 1-72.

Zabowski, D., Thies, W.G., Hatten, J., and Ogden, A., 2007, Soil response to season and interval of prescribed fire in a ponderosa pine forest of the Blue Mountains, Oregon: JFSP Research Project Reports, Paper 120. http://digitalcommons.unl.edu/jfspresearch/120 (accessed January 2017). 


\section{APPENDICES}

Appendix A. Methods, Definitions and Units Measured for Variables.

\begin{tabular}{|c|c|c|c|c|}
\hline Variables & Units & Definition & Method & Method Referencs \\
\hline Basal Area & $\mathrm{m}^{3} / \mathrm{ha}$ & $\begin{array}{l}\text { Basal area is the amount } \\
\text { of an area occupied by } \\
\text { tree stems }>0.13 \mathrm{~m} \\
\text { DBH. }\end{array}$ & $\begin{array}{l}\text { Trees with } \mathrm{DBH}>0.13 \\
\text { m measured; recorded } \\
\text { living or dead, tree } \\
\text { species, and burned or } \\
\text { unburned }\end{array}$ & $\begin{array}{l}\text { Field: Field: FIA } \\
\text { Phase 2, Version } \\
\text { 7.1, p. 38, } 2016\end{array}$ \\
\hline CWD volume & $\mathrm{m}^{3} / \mathrm{ha}$ & $\begin{array}{l}\text { Course woody debris } \\
\text { includes downed, dead } \\
\text { trees and large limbs, } \\
\text { and other woody pieces } \\
\text { that are } \geq 3 \text { inches in } \\
\text { diameter and severed } \\
\text { from their original source } \\
\text { of growth. }\end{array}$ & $\begin{array}{l}\text { Each piece measured } \\
\text { for diameter }(>0.1 \mathrm{~m}) \text {, } \\
\text { length }(>1.5 \mathrm{~m}) \text {, age, } \\
\text { burned or cut, and type } \\
\text { ofCWD: stem, root } \\
\text { wad, compound piece, } \\
\text { or fallen tree }\end{array}$ & $\begin{array}{c}\text { Field: FIA Phase 2, } \\
\text { Version 7.1, p. 137, } \\
2016\end{array}$ \\
\hline Seedling density & $\# / \mathrm{m}^{2}$ & $\begin{array}{l}\text { Very young trees with } \\
\mathrm{DBH}<0.025 \mathrm{~m}\end{array}$ & $\begin{array}{l}\text { Recorded tally of } \\
\text { seedlings with } \\
\text { diameter }<0.025 \mathrm{~m} \text {; } \\
\text { hardwoods }>0.3 \mathrm{~m} \text { tall } \\
\text { and pines }>0.15 \mathrm{~m} \text { tall } \\
\text { within in known area of } \\
\text { microplot }\end{array}$ & $\begin{array}{l}\text { Field: FIA Phase 2, } \\
\text { Version 7.1, p. 68- } \\
\text { 101, } 2016\end{array}$ \\
\hline Sapling density & $\# / \mathrm{m}^{2}$ & $\begin{array}{l}\text { Young trees with DBH } \\
0.025-0.3 \mathrm{~m}\end{array}$ & $\begin{array}{l}\text { Recorded tally of } \\
\text { saplings with diameter } \\
0.025-0.13 \mathrm{~m}\end{array}$ & $\begin{array}{l}\text { Field: FIA Phase 2, } \\
\text { Version 7.1, p. 68- } \\
\text { 101, } 2016\end{array}$ \\
\hline Witness tree & N/A & $\begin{array}{l}\text { Tree near the center of } \\
\text { each subplot used to } \\
\text { easily find subplots; } \\
\text { maintenance of plot } \\
\text { integrity. }\end{array}$ & $\begin{array}{l}\text { Recorder stands with } \\
\text { back to tree and takes } \\
\text { a bearing facing the } \\
\text { center of the subplot } \\
\text { and then measures the } \\
\text { distances from the } \\
\text { center of the subplot to } \\
\text { the tree }\end{array}$ & $\begin{array}{c}\text { Field: FIA Phase 2, } \\
\text { Version 7.1, p. } 7 \\
\text { and } 70,2016\end{array}$ \\
\hline
\end{tabular}




\section{Appendix A continued. Methods, Definitions and Units Measured for Variables.}

\begin{tabular}{|c|c|c|c|c|}
\hline Variables & Units & Definition & Method & Method Referencs \\
\hline Litter depth & $\mathrm{mm}$ & $\begin{array}{l}\text { Litter is the layer of } \\
\text { freshly fallen leaves, } \\
\text { needles, small twigs, } \\
\text { cones, detached bark } \\
\text { pieces, dead moss and } \\
\text { lichens, detached small } \\
\text { chunks of rotted wood, } \\
\text { dead herbaceous stems, } \\
\text { and flower parts. }\end{array}$ & $\begin{array}{l}\text { Sampling frame with } \\
\text { known area; folding } \\
\text { ruler to measure depth } \\
\text { at } 4 \text { locations within } \\
\text { sampling frame }\end{array}$ & $\begin{array}{c}\text { Field: FIA Phase 3, } \\
\text { Version 5.1, p. 3, } \\
2011\end{array}$ \\
\hline Duff depth & $\mathrm{mm}$ & $\begin{array}{l}\text { Duff is the mat-like layer } \\
\text { just below litter layer } \\
\text { and located just above } \\
\text { the soil A-horizon. This } \\
\text { layer is differentiated } \\
\text { from the litter layer in } \\
\text { that the source of this } \\
\text { material can no longer } \\
\text { be identified. }\end{array}$ & $\begin{array}{l}\text { Sampling frame with } \\
\text { known area; folding } \\
\text { ruler to measure depth } \\
\text { at } 4 \text { locations within } \\
\text { sampling frame }\end{array}$ & $\begin{array}{l}\text { Field: FIA Phase 3, } \\
\text { Version 5.1, p. 3, } \\
2011\end{array}$ \\
\hline Bulk Density & $\mathrm{g} / \mathrm{cm}^{3}$ & $\begin{array}{l}\text { Bulk density is an } \\
\text { indicator of soil } \\
\text { compaction, available } \\
\text { water capacity, total } \\
\text { pore space, soil health } \\
\text { and other soil } \\
\text { properties. }\end{array}$ & $\begin{array}{l}\text { Impact-drive soil core } \\
\text { sampler; bulk density } \\
\text { ring }\end{array}$ & $\begin{array}{l}\text { Field: FIA Phase 3, } \\
\text { Version 5.1, p. 14- } \\
\text { 24, } 2011\end{array}$ \\
\hline Organic Matter & $\%$ & $\begin{array}{l}\text { Organic matter is the } \\
\text { plant and animal residue } \\
\text { in the soil at various } \\
\text { stages of decomposition. }\end{array}$ & $\begin{array}{l}\text { Portion of the sampled } \\
\text { obtained from bulk } \\
\text { density samples for } \\
\text { analysis }\end{array}$ & $\begin{array}{l}\text { Laboratory: } \\
\text { OEWRI SOP } \\
\text { (2030R02 Org } \\
\text { Matter LOI) }\end{array}$ \\
\hline Soil Texture & $\mu \mathrm{m}$ & $\begin{array}{l}\text { The textural class of soil } \\
\text { is determined by the } \\
\text { percent of sand, silt, and } \\
\text { clay in the fraction of the } \\
\text { soil that is less than } 2 \\
\text { millimeters in diameter. } \\
\text { Soil texture influences } \\
\text { soil infiltration rates. }\end{array}$ & $\begin{array}{l}\text { Portion of the sampled } \\
\text { obtained from bulk } \\
\text { density samples for } \\
\text { analysis }\end{array}$ & $\begin{array}{c}\text { Laboratory: OEWRI } \\
\text { SOP (Particle Sizer } \\
\text { R01.doc) }\end{array}$ \\
\hline
\end{tabular}




\section{Appendix B - Site Descriptions, Characteristics and Management History}

Appendix B-1. Site Type, Year Burned and Management History.

\begin{tabular}{|c|c|c|c|c|}
\hline Site & Stand Type & $\begin{array}{c}\text { Number of times } \\
\text { burned }\end{array}$ & Years burned & USFS Timber Harvest Activity \\
\hline 1 & Oak & 0 & Never & Commercial thinning- 2011 \\
\hline 2 & Oak & 4 & $2007,2009,2013,2016$ & Sanitation Cut- 1981 \\
\hline 3 & Oak & 4 & $2007,2009,2013,2016$ & Salvage Cut- 1997 \\
\hline 4 & Oak & 0 & Never & None \\
\hline 5 & Mixed & 0 & Never & Commercial thinning- 2008 \\
\hline 6 & Mixed & 0 & Never & Commercial thinning- 2009 \\
\hline 7 & Oak & 2 & 2012,2016 & None \\
\hline 8 & Oak & 2 & 2012,2016 & None \\
\hline 9 & Oak & 2 & 2012,2016 & None \\
\hline 10 & Oak & 1 & 2011 & Stand clear-cut- 1987 \\
\hline 11 & Oak & 1 & 2011 & Salvage Cut- 1991 \\
\hline 12 & Pine & 3 & $2011,2012,2015$ & None \\
\hline 13 & Oak & 2 & 2012,2015 & None \\
\hline 14 & Oak & 2 & 2012,2015 & None \\
\hline 15 & Oak & 3 & $2009,2012,2015$ & Sanitation Cut- 1981 \\
\hline 16 & Oak & 2 & 2012,2015 & Sanitation Cut- 1985 \\
\hline 17 & Oak & 3 & $2012,2014,2016$ & Stand clear-cut- 1984 \\
\hline 18 & Pine & 4 & $2009,2012,2014,2016$ & None \\
\hline 19 & Oak & 3 & 2012, 2014, 2016 & Improvement cut- 1997 \\
\hline 20 & Oak & 4 & $2009,2012,2014,2016$ & Stand clear-cut- 1985 \\
\hline 21 & Mixed & 4 & $2009,2012,2014,2016$ & Commercial thin- 1994 \\
\hline 22 & Mixed & 0 & Never & Stand clear-cut- 1991 \\
\hline 23 & Pine & 0 & Never & None \\
\hline 24 & Pine & 0 & Never & None \\
\hline 25 & Oak & 2 & 2010,2014 & Salvage cut- 1990 \\
\hline 26 & Mixed & 1 & 2016 & Stand clear-cut- 1989 \\
\hline 27 & Oak & 0 & Never & Salvage cut- 1991 \\
\hline 28 & Oak & 4 & $2008,2009,2012,2015$ & Stand clear-cut- 1982 \\
\hline 29 & Oak & 1 & 2011 & Commercial thinning- 2014 \\
\hline 30 & Pine & 4 & $2007,2009,2013,2016$ & Salvage cut- 1982 \\
\hline
\end{tabular}


Appendix B-2. Management Definitions.

\begin{tabular}{|c|c|}
\hline Type of management & Definition (USDA-FS, 2017b) \\
\hline Commercial thinning & $\begin{array}{l}\text { A treatment made to reduce stand density of trees primarily to improve } \\
\text { growth, enhance forest health, or to recover potential mortality. Includes } \\
\text { crown thinning (thinning from above, high thinning), free thinning, low } \\
\text { thinning (thinning from below), mechanical thinning (geometric thinning), } \\
\text { and selection thinning (dominant thinning). }\end{array}$ \\
\hline Improvement cut & $\begin{array}{l}\text { A treatment made in a stand, pole-sized or larger, primarily to improve } \\
\text { composition and quality by removing less desirable trees of any species. }\end{array}$ \\
\hline Salvage cutting & $\begin{array}{l}\text { The removal of dead trees or trees being damaged or dying due to } \\
\text { injurious agents other than competition, to recover value that would } \\
\text { otherwise be lost. }\end{array}$ \\
\hline Sanitation cutting & $\begin{array}{l}\text { The removal of trees to improve stand health by stopping or reducing } \\
\text { actual or anticipated spread of insects and disease }\end{array}$ \\
\hline Stand clearcutting & $\begin{array}{l}\text { A type of clearcutting where removal of essentially all trees in the previous } \\
\text { stand, producing a fully exposed microclimate for the development of a } \\
\text { new age class. Under a two-aged method, varying numbers of reserve } \\
\text { trees are not harvested to attain goals other than regeneration. }\end{array}$ \\
\hline
\end{tabular}


Appendix B-3. Site Characteristics.

\begin{tabular}{|c|c|c|c|c|c|}
\hline Site & $\begin{array}{l}\text { Avgerage } \\
\text { slope }(\%)\end{array}$ & $\begin{array}{c}\text { Average basal } \\
\text { Area (m2/ha) }\end{array}$ & $\begin{array}{c}\text { Average CWD } \\
(\mathrm{m} 3 / \mathrm{ha})\end{array}$ & $\begin{array}{l}\text { Average sapling } \\
\text { density }(\# / \mathrm{m} 2)\end{array}$ & $\begin{array}{c}\text { Average seedling } \\
\text { density }(\# / \mathrm{m} 2)\end{array}$ \\
\hline 1 & 2.65 & 33.54 & 28.70 & 0.02 & 0.97 \\
\hline 2 & 5.24 & 32.16 & 0.14 & 0.04 & 0.40 \\
\hline 3 & 4.22 & 21.18 & 8.07 & 0.07 & 0.65 \\
\hline 4 & 3.51 & 20.76 & 22.61 & 0.13 & 0.47 \\
\hline 5 & 1.55 & 26.94 & 66.23 & 0.83 & 0.34 \\
\hline 6 & 3.10 & 28.44 & 108.79 & 0.05 & 0.97 \\
\hline 7 & 5.27 & 27.91 & 6.46 & 0.40 & 0.97 \\
\hline 8 & 8.24 & 27.62 & 25.91 & 0.58 & 0.13 \\
\hline 9 & 3.96 & 25.46 & 16.60 & 0.22 & 0.60 \\
\hline 10 & 5.55 & 25.06 & 5.67 & 0.70 & 0.36 \\
\hline 11 & 1.78 & 25.47 & 1.18 & 0.43 & 0.65 \\
\hline 12 & 3.52 & 37.67 & 15.54 & 0.00 & 0.45 \\
\hline 13 & 3.16 & 23.17 & 7.58 & 0.13 & 1.37 \\
\hline 14 & 3.54 & 37.31 & 31.30 & 0.02 & 0.81 \\
\hline 15 & 5.20 & 23.13 & 6.59 & 0.09 & 1.23 \\
\hline 16 & 4.22 & 24.27 & 7.19 & 0.42 & 0.25 \\
\hline 17 & 5.08 & 27.10 & 14.31 & 1.14 & 0.94 \\
\hline 18 & 5.93 & 41.69 & 56.93 & 1.86 & 2.27 \\
\hline 19 & 2.08 & 28.04 & 15.40 & 1.14 & 0.87 \\
\hline 20 & 3.96 & 21.39 & 2.43 & 0.45 & 0.69 \\
\hline 21 & 3.66 & 36.94 & 113.10 & 0.56 & 0.83 \\
\hline 22 & 4.36 & 26.20 & 2.99 & 0.63 & 0.52 \\
\hline 23 & 2.74 & 39.72 & 21.08 & 0.52 & 0.34 \\
\hline 24 & 8.58 & 37.55 & 21.52 & 0.22 & 0.27 \\
\hline 25 & 1.60 & 24.06 & 2.50 & 1.30 & 1.01 \\
\hline 26 & 2.78 & 28.33 & 0.25 & 0.29 & 0.32 \\
\hline 27 & 5.04 & 16.83 & 27.36 & 0.70 & 0.29 \\
\hline 28 & 3.94 & 17.60 & 28.22 & 0.72 & 0.52 \\
\hline 29 & 1.45 & 34.04 & 49.57 & 0.88 & 0.07 \\
\hline 30 & 3.53 & 21.69 & 46.45 & 0.90 & 0.13 \\
\hline
\end{tabular}




\section{Appendix C. Photo Log.}

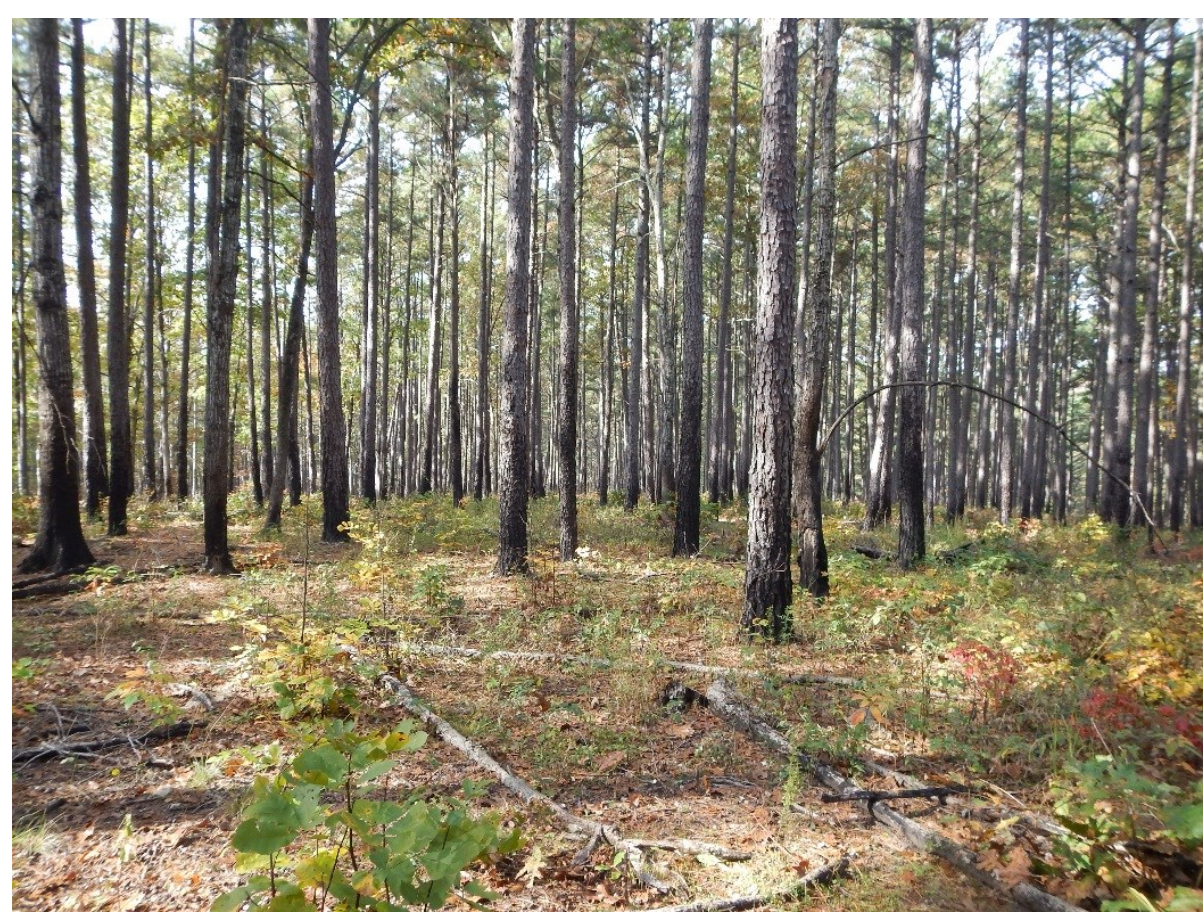

Appendix C-1. Site 18, pine dominated; burned stand; October 2016.

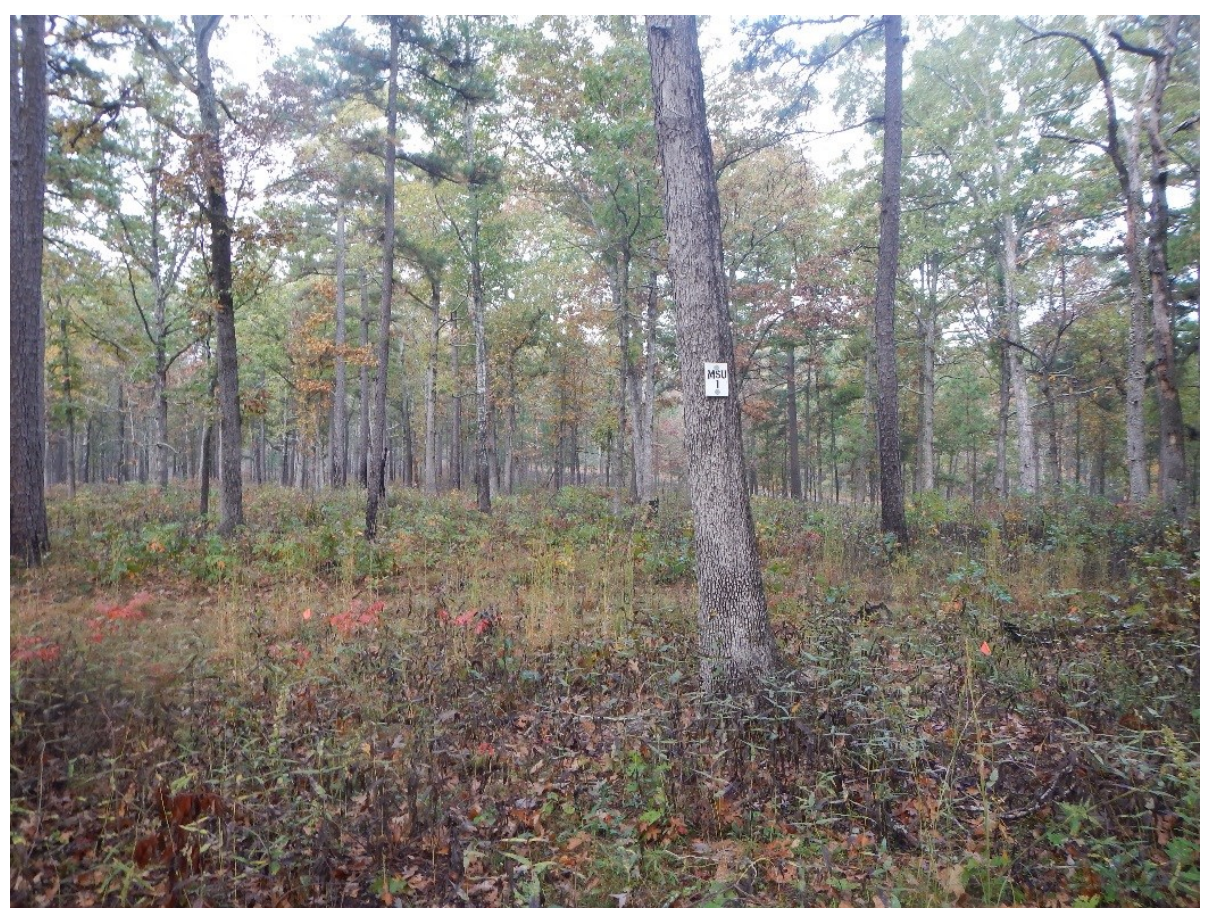

Appendix C-2. Site 19 near state highway J; old logging road behind subplot 1-MSU 1 witness tree; oak dominated; burned stand; October 2016. 


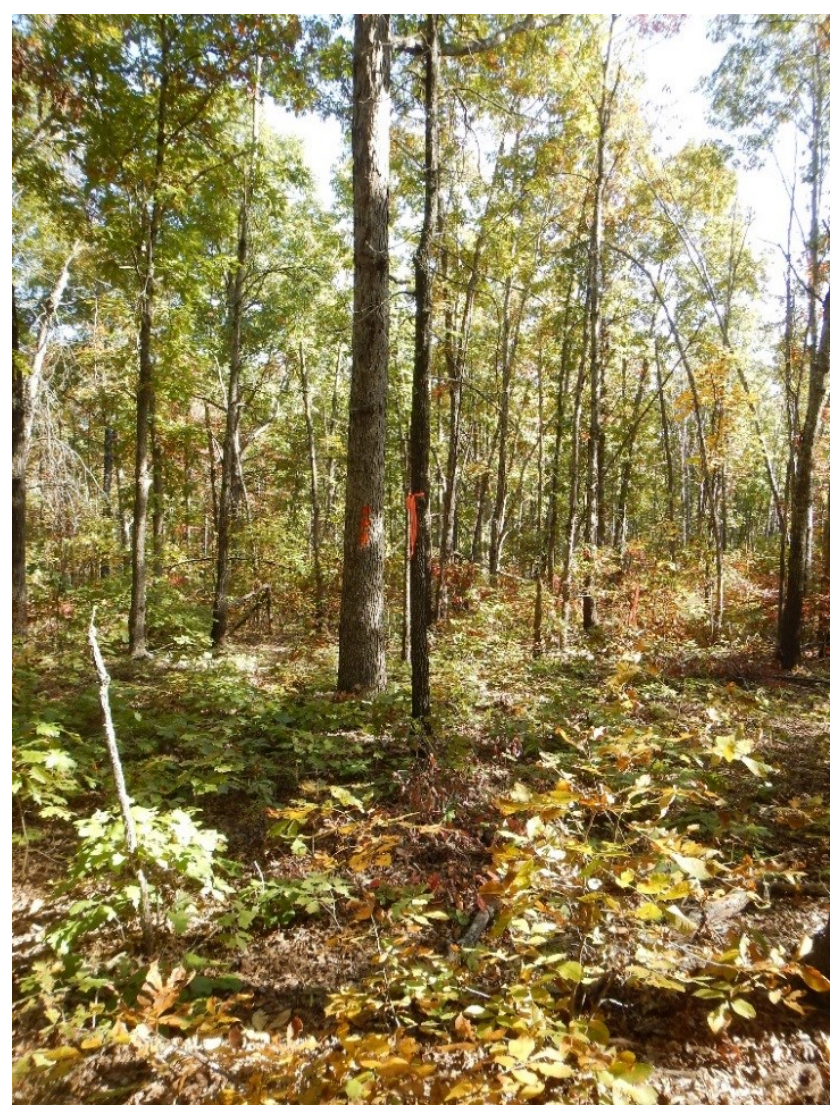

Appendix C-3. Site 8 subplot 3; oak burned stand; Examples of understory flora; October 2015.

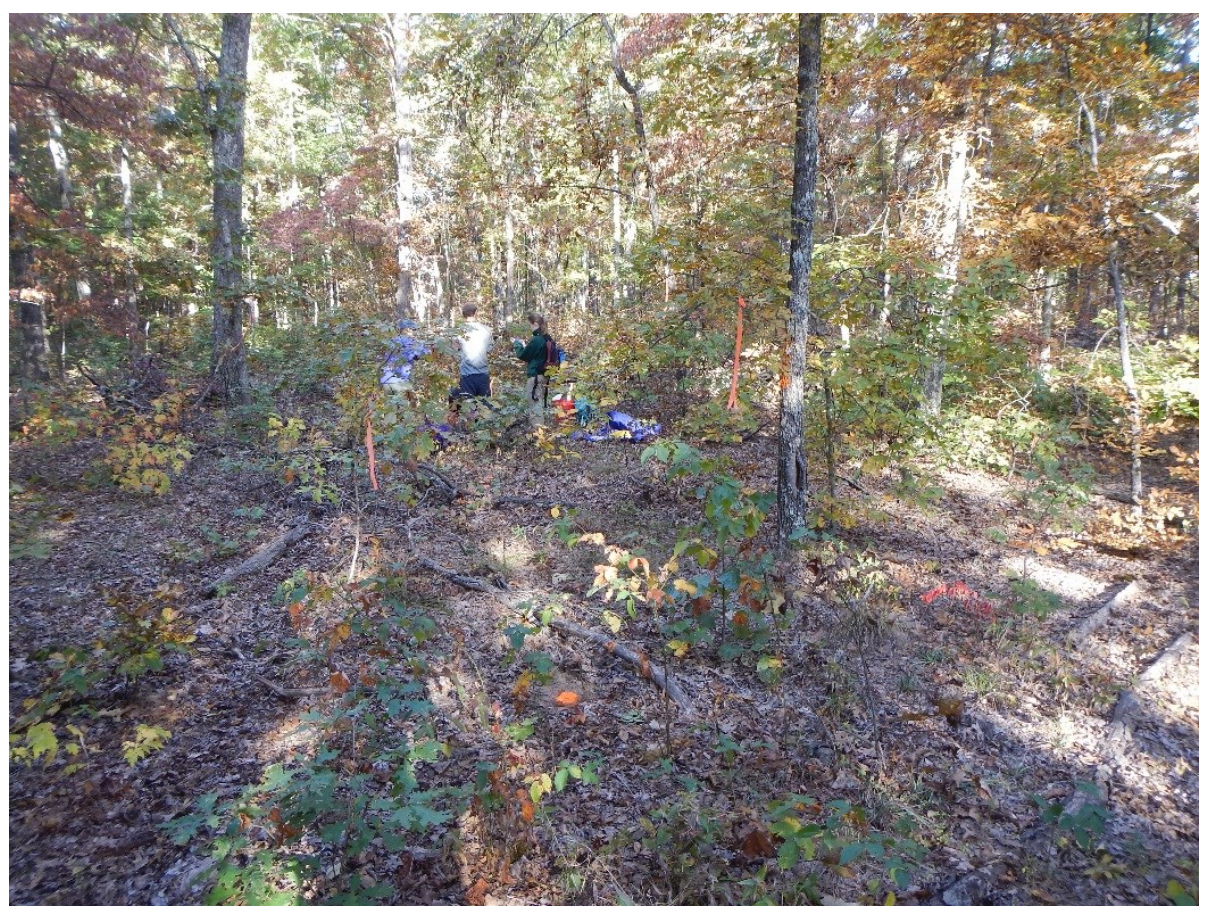

Appendix C-4. Site 5, mixed, unburned stand; October 2015. 


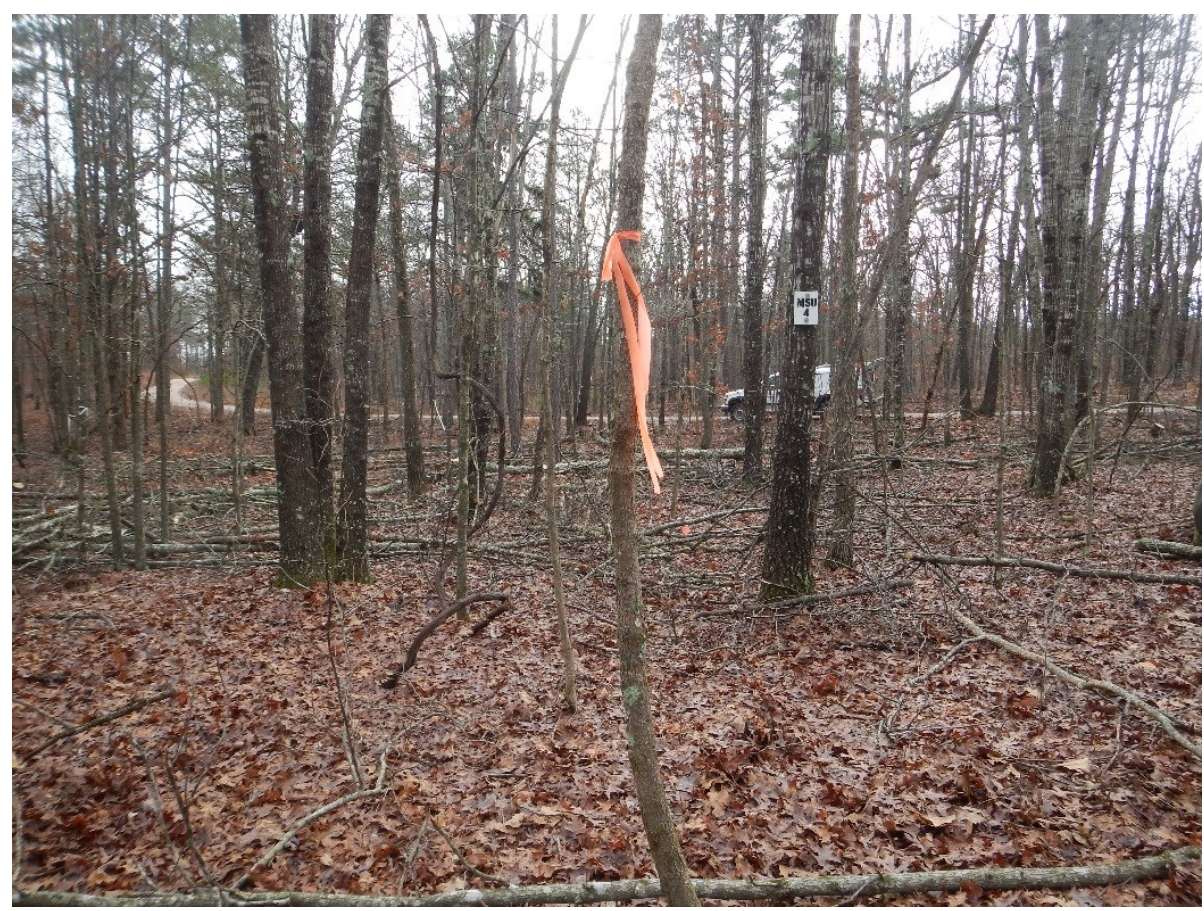

Appendix C-5: Site 5, subplot 4; mixed, unburned stand. Evidence of TSI. December 2015 - Leaf off season.

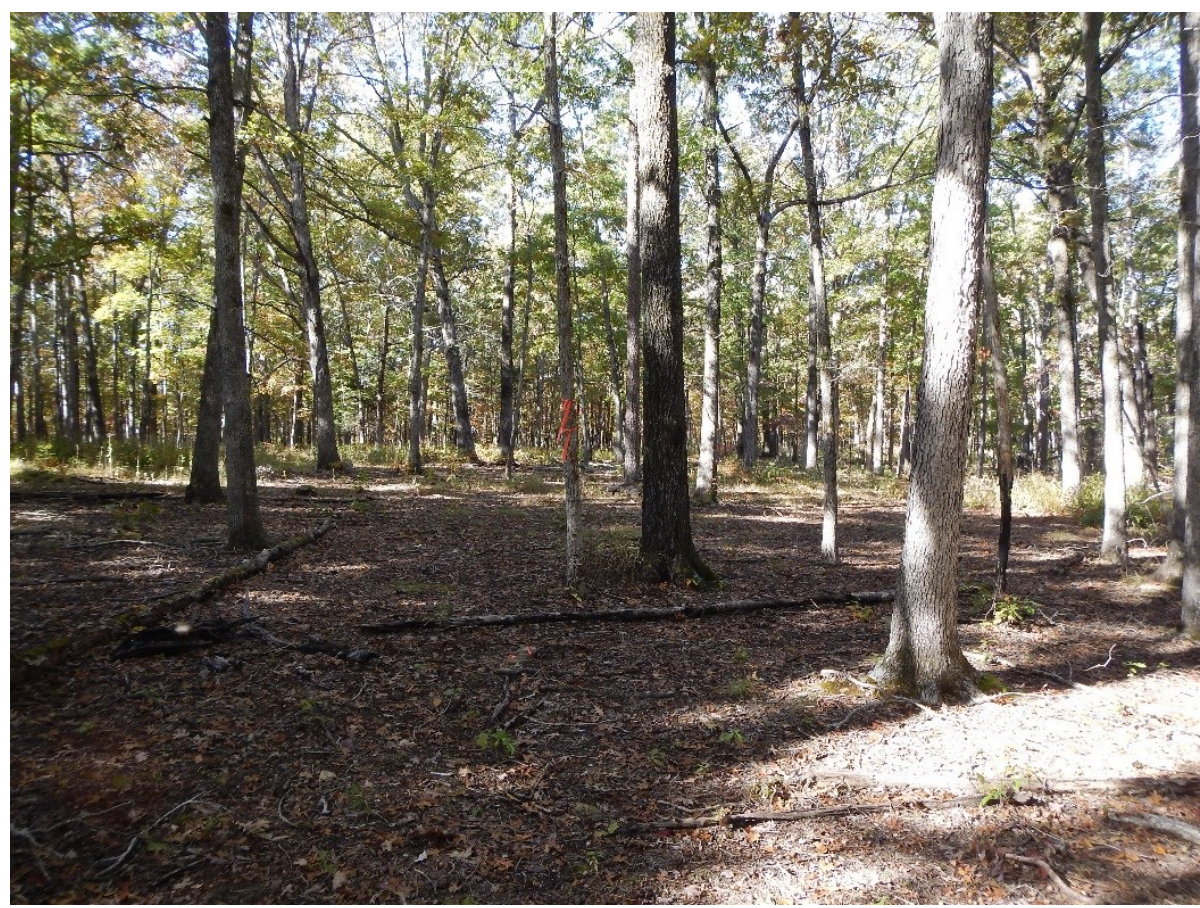

Appendix C-6: Site 14 subplot 4, oak burned stand; Example of seasonal variation; October 2015. 


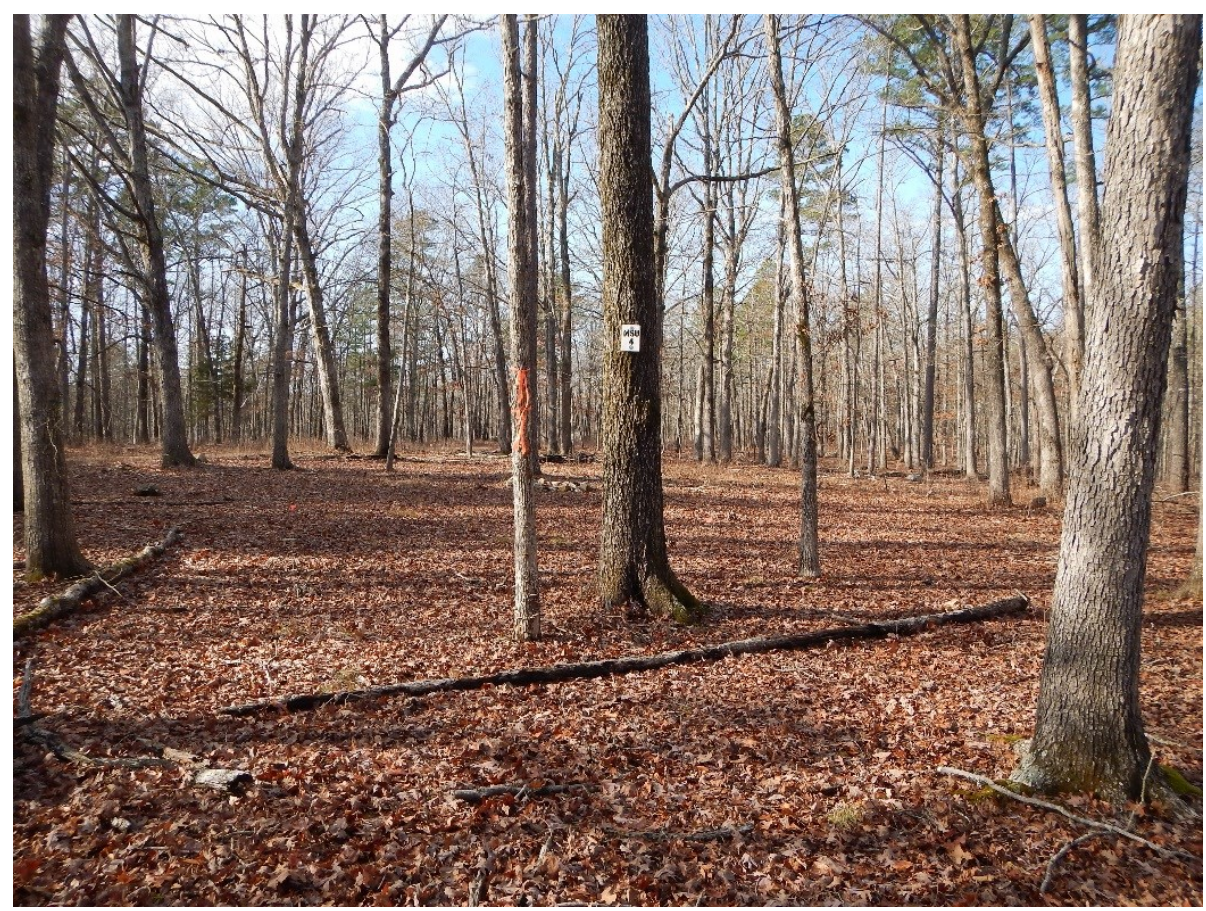

Appendix C-7. Site 14 subplot 4, oak burned stand; Example of seasonal variation; December 2015.

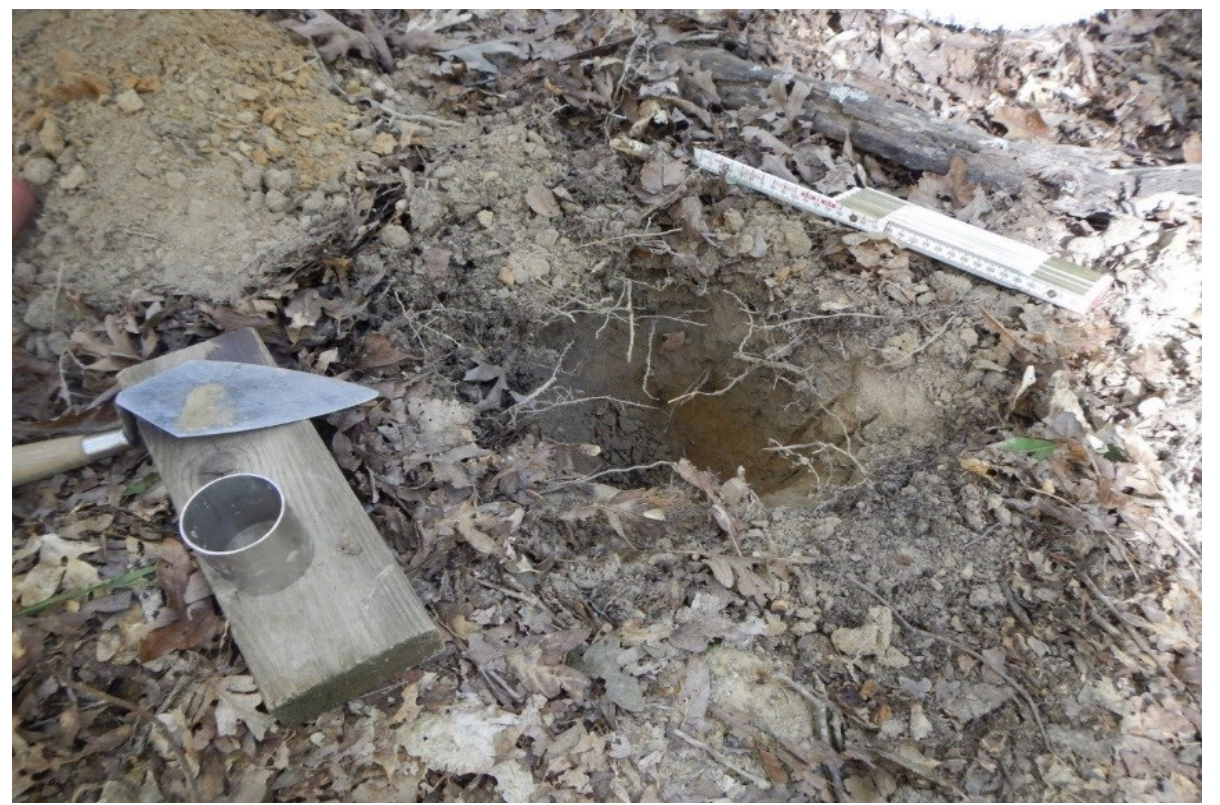

Appendix C-8. Site 1 subplot 2, oak unburned stand; bulk density ring and sampling tools; October 2015. 


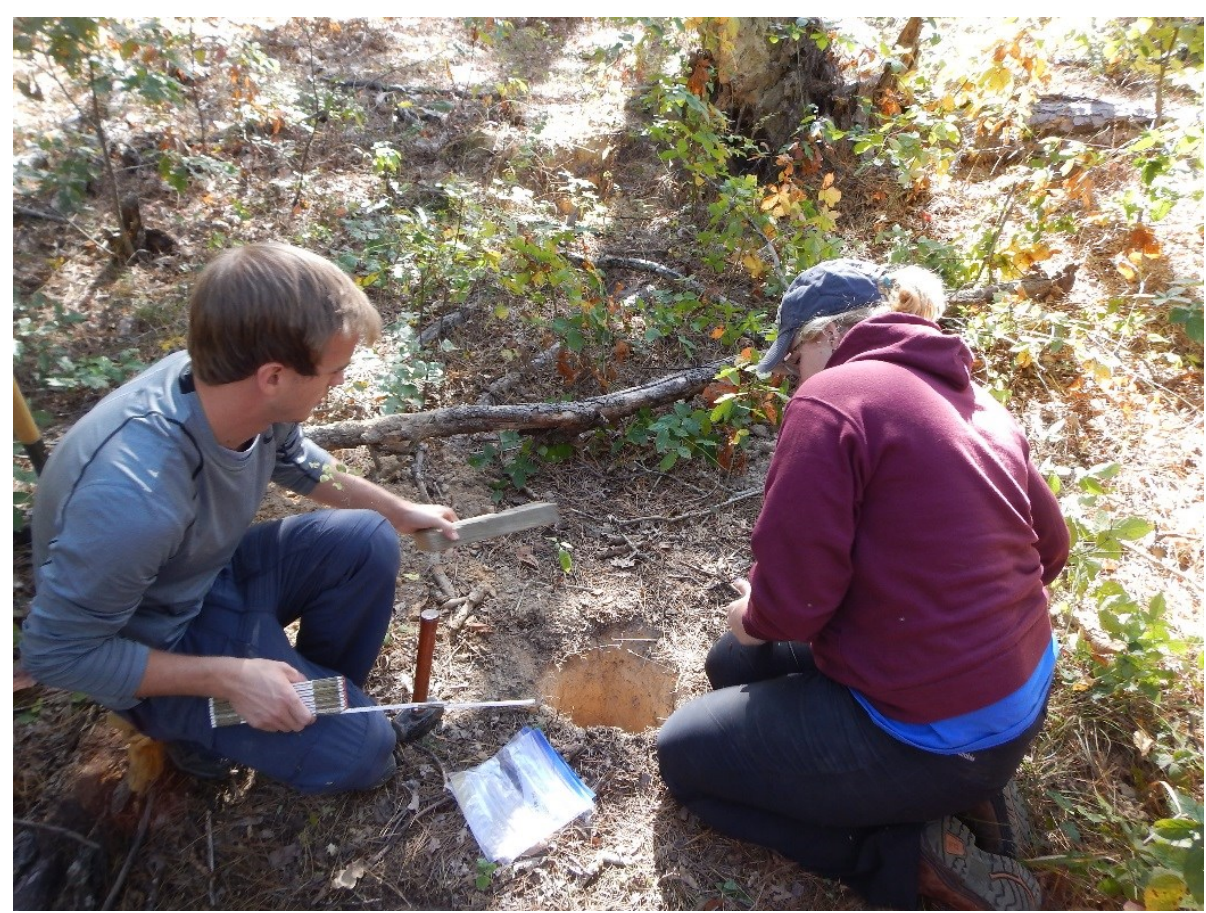

Appendix C-9. Site 5 subplot 4; mixed unburned stand; Sampling October 2015.

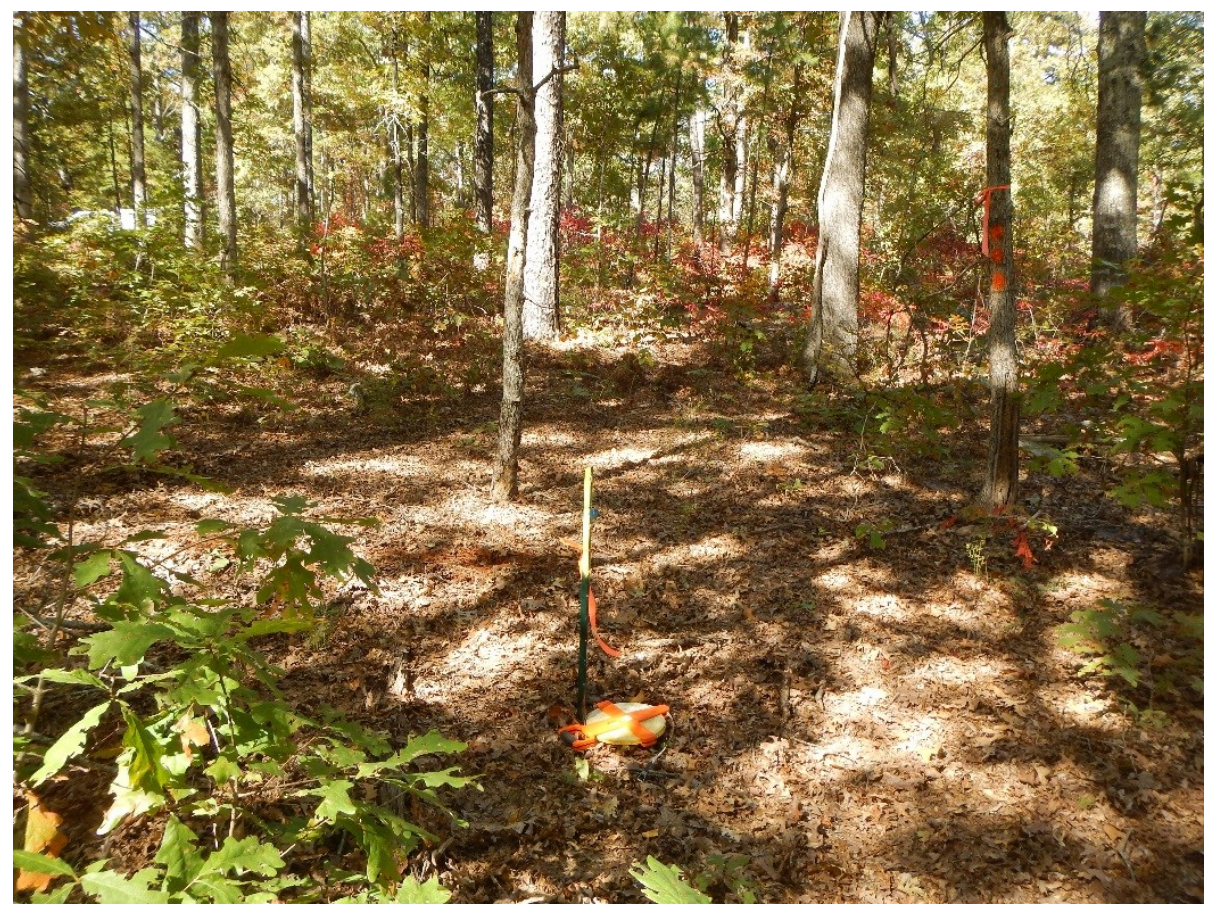

Appendix C-10. Site 7, subplot 1, stake at center; oak burned stand; October 2015. 


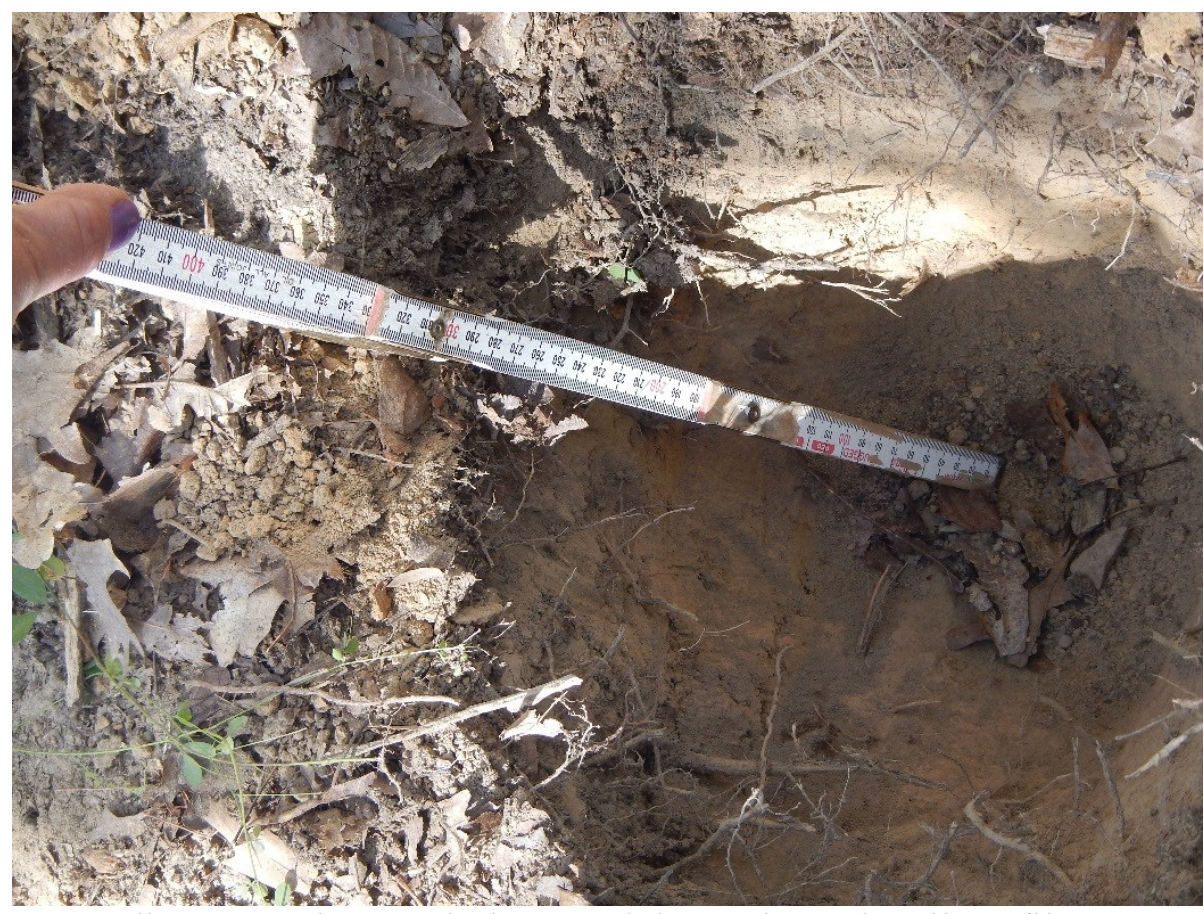

Appendix C-11. Site 9, subplot 2; oak burned stand; soil profile 0 to $\sim 300 \mathrm{~mm}$; October 2015.

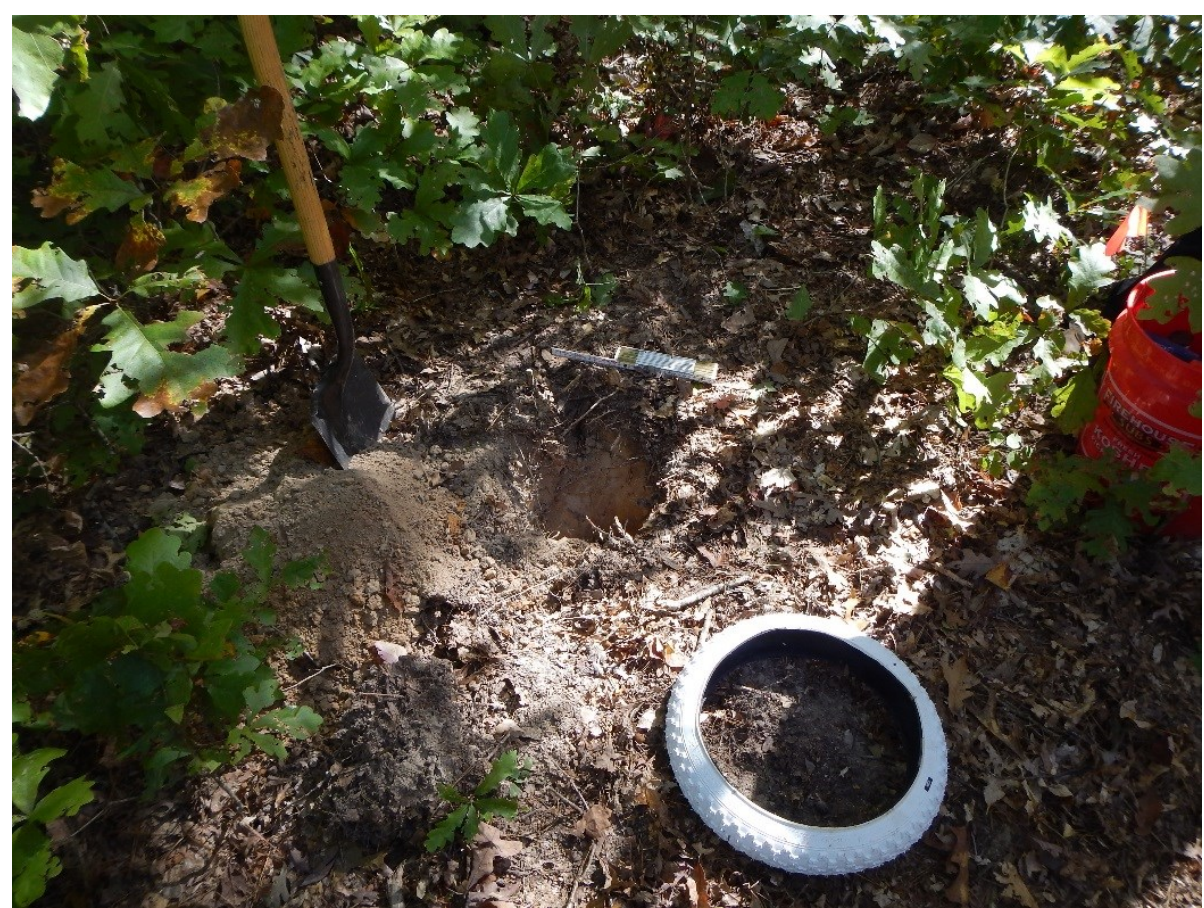

Appendix C-12. Site 1, subplot 3; Unburned oak stand; equipment; October 2015. 


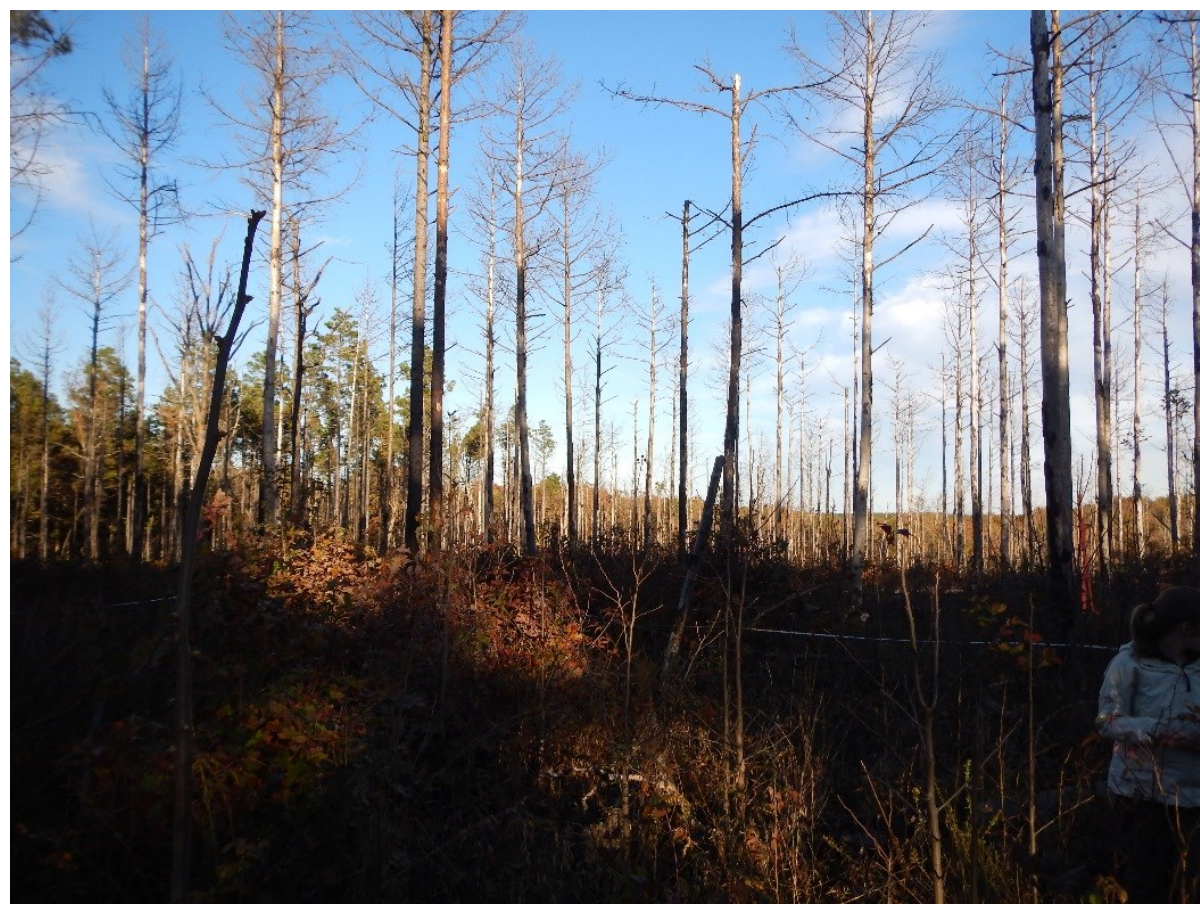

Appendix C-13. Site 30, subplot 1; Burned pine stand; Canopy consumption; October 2015.

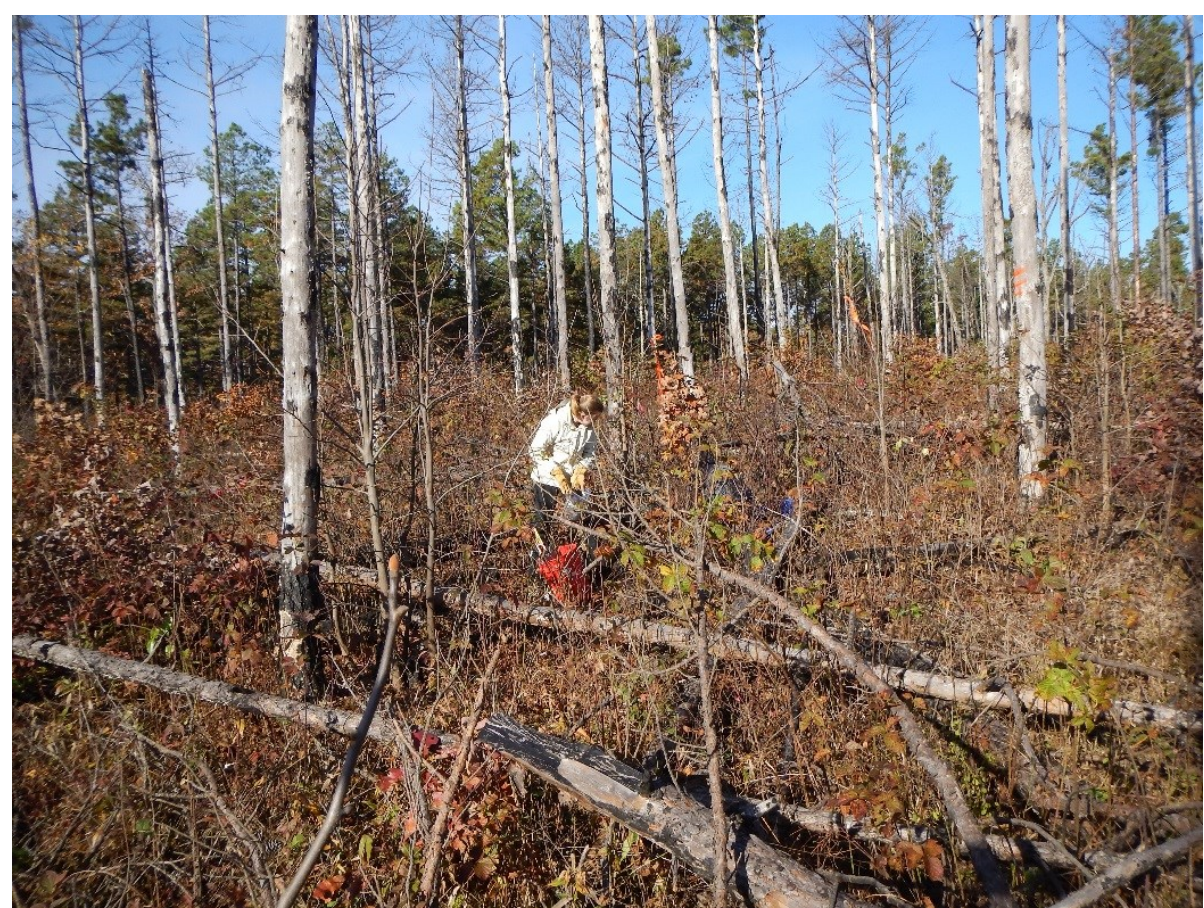

Appendix C-14. Site 30, subplot 3; Burned pine stand; Canopy consumption; October 2015. 


\section{Appendix D. Site Locations, Witness Trees and Tree Type.}

Appendix D-1. Site Locations.

\begin{tabular}{|c|c|c|}
\hline Site & $\begin{array}{c}\text { Center Subplot-1 } \\
\text { Long }(\mathrm{X})\end{array}$ & $\begin{array}{c}\text { Center Subplot-1 } \\
\text { Lat (Y) }\end{array}$ \\
\hline 1 & 659437.301 & 4080062.227 \\
\hline 2 & 658875.5559 & 4083857.655 \\
\hline 3 & 658982.4524 & 4083671.949 \\
\hline 4 & 661010.5659 & 4081082.027 \\
\hline 5 & 660934.8276 & 4078419.459 \\
\hline 6 & 661537.6508 & 4078592.055 \\
\hline 7 & 666461.5999 & 4076799.976 \\
\hline 8 & 666368.7261 & 4076037.302 \\
\hline 9 & 666284.6427 & 4075910.204 \\
\hline 10 & 671201.2695 & 4079522.863 \\
\hline 11 & 670704.7171 & 4078568.883 \\
\hline 12 & 664710.9456 & 4081125.878 \\
\hline 13 & 665466.0678 & 4080858.674 \\
\hline 14 & 666409.5483 & 4080644.465 \\
\hline 15 & 667319.9821 & 4080481.88 \\
\hline 16 & 667211.7329 & 4083836.521 \\
\hline 17 & 665587.2334 & 4085290.582 \\
\hline 18 & 665887.5198 & 4084607.001 \\
\hline 19 & 661828.6691 & 4084875.617 \\
\hline 20 & 667076.1819 & 4083853.867 \\
\hline 21 & 667437.3312 & 4084262.745 \\
\hline 22 & 671770.6544 & 4082957.121 \\
\hline 23 & 672045.6205 & 4082259.346 \\
\hline 24 & 674153.1877 & 4084786.917 \\
\hline 25 & 669972.4206 & 4076860.041 \\
\hline 26 & 669244.696 & 4078284.938 \\
\hline 27 & 669937.9524 & 4078471.136 \\
\hline 28 & 661979.413 & 4078461.26 \\
\hline 29 & 661662.572 & 4079191.537 \\
\hline 30 & 659106.4744 & 4083386.166 \\
\hline
\end{tabular}


Appendix D-2. Site Witness Trees and Tree Type.

\begin{tabular}{|c|c|c|c|c|}
\hline \multirow[b]{2}{*}{ Site } & \multirow[b]{2}{*}{ Subplot } & \multicolumn{3}{|c|}{ Witness tree locations } \\
\hline & & Azimuth $\left(^{\circ}\right)$ & Distance (m) & Tree Type \\
\hline \multirow{4}{*}{1} & 1 & 55 & 4 & White oak \\
\hline & 2 & 180 & 2.5 & White oak \\
\hline & 3 & 340 & 5 & pine \\
\hline & 4 & 25 & 4.5 & red oak \\
\hline \multirow{4}{*}{2} & 1 & 350 & 4 & White oak \\
\hline & 2 & 280 & 1 & black oak \\
\hline & 3 & 260 & 2.5 & black oak \\
\hline & 4 & 0 & 3 & pine \\
\hline \multirow{4}{*}{3} & 1 & 270 & 7 & White oak \\
\hline & 2 & 180 & 0.5 & black oak \\
\hline & 3 & 190 & 2 & pine \\
\hline & 4 & 120 & 4.5 & White oak \\
\hline \multirow{4}{*}{4} & 1 & 160 & 3 & black oak \\
\hline & 2 & 250 & 2 & White oak \\
\hline & 3 & 280 & 1.5 & White oak \\
\hline & 4 & 340 & 1.5 & pine \\
\hline \multirow{4}{*}{5} & 1 & 160 & 4 & White oak \\
\hline & 2 & 85 & 1 & black oak \\
\hline & 3 & 70 & 8.5 & White oak \\
\hline & 4 & 300 & 4.5 & black oak \\
\hline \multirow{4}{*}{6} & 1 & 290 & 3 & pine \\
\hline & 2 & 0 & 3.5 & black oak \\
\hline & 3 & 230 & 2 & pine \\
\hline & 4 & 30 & 3.5 & pine \\
\hline \multirow{4}{*}{7} & 1 & 50 & 4 & black oak \\
\hline & 2 & 270 & 0.5 & oak \\
\hline & 3 & 290 & 7.5 & oak \\
\hline & 4 & 220 & 2 & oak \\
\hline \multirow{4}{*}{8} & 1 & 290 & 5 & pine \\
\hline & 2 & 250 & 7 & oak \\
\hline & 3 & 130 & 2 & black oak \\
\hline & 4 & 90 & 0.5 & pine \\
\hline \multirow{4}{*}{9} & 1 & 110 & 4 & White oak \\
\hline & 2 & 90 & 1.5 & oak \\
\hline & 3 & 180 & 1 & oak \\
\hline & 4 & 340 & 3 & oak \\
\hline \multirow{4}{*}{10} & 1 & 90 & 2.5 & White oak \\
\hline & 2 & 180 & 2 & black oak \\
\hline & 3 & 300 & 1 & oak \\
\hline & 4 & 160 & 0.5 & oak \\
\hline
\end{tabular}


Appendix D-2 continued. Site Witness Trees and Tree Type.

\begin{tabular}{|c|c|c|c|c|}
\hline \multirow[b]{2}{*}{ Site } & \multirow[b]{2}{*}{ Subplot } & \multicolumn{3}{|c|}{ Witness tree locations } \\
\hline & & Azimuth $\left(^{\circ}\right)$ & Distance (m) & Tree Type \\
\hline \multirow{4}{*}{11} & 1 & 115 & 6 & oak \\
\hline & 2 & 280 & 1 & oak \\
\hline & 3 & 180 & 0.5 & oak \\
\hline & 4 & 180 & 0.5 & oak \\
\hline \multirow{4}{*}{12} & 1 & 90 & 3 & pine \\
\hline & 2 & 180 & 1 & pine \\
\hline & 3 & 0 & 2 & pine \\
\hline & 4 & 50 & 0.25 & oak \\
\hline \multirow{4}{*}{13} & 1 & 270 & 2 & oak \\
\hline & 2 & 90 & 0.5 & oak \\
\hline & 3 & 340 & 6 & pine \\
\hline & 4 & 330 & 3.5 & pine \\
\hline \multirow{4}{*}{14} & 1 & 60 & 3.5 & oak \\
\hline & 2 & 270 & 0.5 & oak \\
\hline & 3 & 0 & 4 & oak \\
\hline & 4 & 90 & 2 & oak \\
\hline \multirow{4}{*}{15} & 1 & 30 & 1.5 & oak \\
\hline & 2 & 40 & 1.5 & oak \\
\hline & 3 & 260 & 1.5 & oak \\
\hline & 4 & 60 & 0.5 & pine \\
\hline \multirow{4}{*}{16} & 1 & $300 \mathrm{~W}-\mathrm{NW}$ & 2.5 & White oak \\
\hline & 2 & $180 \mathrm{~S}$ & 1 & oak \\
\hline & 3 & $320 \mathrm{NW}$ & 0.1 & White oak \\
\hline & 4 & $80 \mathrm{E}$ & 3 & pine \\
\hline \multirow{4}{*}{17} & 1 & $70 \mathrm{E} \mathrm{NE}$ & 5 & Not recorded \\
\hline & 2 & $255 \mathrm{~W}-\mathrm{SW}$ & 5 & Not recorded \\
\hline & 3 & $190 \mathrm{~S}$ & 3 & Not recorded \\
\hline & 4 & $0 \mathrm{~N}$ & 4 & Not recorded \\
\hline \multirow{4}{*}{18} & 1 & $280 \mathrm{~W}$ & 4 & pine \\
\hline & 2 & $200 \mathrm{~S}$ & 4 & oak \\
\hline & 3 & $280 \mathrm{~W}$ & 2.5 & pine \\
\hline & 4 & $40 \mathrm{NE}$ & 3 & pine \\
\hline \multirow{4}{*}{19} & 1 & $120 \mathrm{E}-\mathrm{SE}$ & 6 & oak \\
\hline & 2 & $20 \mathrm{~N}$ & 3 & oak \\
\hline & 3 & $60 \mathrm{E}-\mathrm{NE}$ & 5 & White oak \\
\hline & 4 & $200 \mathrm{~S}$ & 4 & pine \\
\hline \multirow{4}{*}{20} & 1 & - & - & - \\
\hline & 2 & $140 \mathrm{SE}$ & 3.5 & pine \\
\hline & 3 & $220 \mathrm{~S}-\mathrm{SW}$ & 4 & pine \\
\hline & 4 & S-SW & 1 & White oak \\
\hline
\end{tabular}


Appendix D-2 continued. Site Witness Trees and Tree Type.

\begin{tabular}{|c|c|c|c|c|}
\hline \multirow[b]{2}{*}{ Site } & \multirow[b]{2}{*}{ Subplot } & \multicolumn{3}{|c|}{ Witness tree locations } \\
\hline & & Azimuth $\left(^{\circ}\right)$ & Distance (m) & Tree Type \\
\hline \multirow{4}{*}{21} & 1 & $330 \mathrm{~N}-\mathrm{NW}$ & 5 & pine \\
\hline & 2 & $160 \mathrm{~S}$ & 3 & pine \\
\hline & 3 & $320 \mathrm{NW}$ & 0.6 & pine \\
\hline & 4 & $10 \mathrm{~N}$ & 0.4 & pine \\
\hline \multirow{4}{*}{22} & 1 & $270 \mathrm{~W}$ & 3 & White oak \\
\hline & 2 & $190 \mathrm{~S}$ & 2 & White oak \\
\hline & 3 & $40 \mathrm{NE}$ & 3 & pine \\
\hline & 4 & $160 \mathrm{~S}$ & 3.5 & oak \\
\hline \multirow{4}{*}{23} & 1 & $10 \mathrm{~N}$ & 2.5 & pine \\
\hline & 2 & $290 \mathrm{~W}$ & 2 & pine \\
\hline & 3 & $320 \mathrm{NW}$ & 6 & White oak \\
\hline & 4 & $50 \mathrm{NE}$ & 4 & oak \\
\hline \multirow{4}{*}{24} & 1 & $280 \mathrm{~W}$ & 3 & pine \\
\hline & 2 & $190 \mathrm{~S}$ & 2 & pine \\
\hline & 3 & 300 NW-W & 2 & pine \\
\hline & 4 & $0 \mathrm{~N}$ & 2 & pine \\
\hline \multirow{4}{*}{25} & 1 & $160 \mathrm{~S}$ & 2.5 & Ash? \\
\hline & 2 & $190 \mathrm{~S}$ & 1.5 & oak \\
\hline & 3 & $240 \mathrm{SW}$ & 5 & oak \\
\hline & 4 & $50 \mathrm{NE}$ & 4 & oak \\
\hline \multirow{4}{*}{26} & 1 & $270 \mathrm{~W}$ & 3.5 & oak \\
\hline & 2 & $220 \mathrm{SW}$ & 2.5 & White oak \\
\hline & 3 & $320 \mathrm{NW}$ & 3.5 & White oak \\
\hline & 4 & $120 \mathrm{E}-\mathrm{SE}$ & 0.3 & White oak \\
\hline \multirow{4}{*}{27} & 1 & $10 \mathrm{~N}$ & 2.5 & White oak \\
\hline & 2 & $210 \mathrm{~S}$ & 6 & Hickory \\
\hline & 3 & $220 \mathrm{~S}-\mathrm{SW}$ & 2.5 & White oak \\
\hline & 4 & $100 \mathrm{E}$ & 3.5 & White oak \\
\hline \multirow{4}{*}{28} & 1 & $0 \mathrm{~N}$ & 2 & White oak \\
\hline & 2 & $160 \mathrm{~S}$ & 3.5 & oak \\
\hline & 3 & $300 \mathrm{SW}-\mathrm{W}$ & 2.5 & oak \\
\hline & 4 & $80 \mathrm{E}$ & 1.5 & oak \\
\hline \multirow{4}{*}{29} & 1 & $160 \mathrm{~S}$ & 2 & White oak \\
\hline & 2 & $160 \mathrm{~S}$ & 5.5 & White oak \\
\hline & 3 & $110 \mathrm{E}$ & 4 & black gum? \\
\hline & 4 & $340 \mathrm{~N}$ & 2.5 & White oak \\
\hline \multirow{4}{*}{30} & 1 & $70 \mathrm{E} \mathrm{NE}$ & 2.5 & pine \\
\hline & 2 & $10 \mathrm{~N}$ & 6 & pine \\
\hline & 3 & $180 \mathrm{~S}$ & 1 & dead pine \\
\hline & 4 & $330 \mathrm{NW}$ & 2.5 & pine \\
\hline
\end{tabular}




\section{Appendix E. Subplot Vegetation Form.}

\begin{tabular}{|l|l|}
\hline Site & Subplot \\
\hline
\end{tabular}

Equipment per team

$30 \mathrm{~m}$ to $100 \mathrm{~m}$ tapeline

8 wire flags

shovel and trowel

Clipboard, pen/pencils, and forms

Stadia rod and folding ruler ( $\mathrm{mm}$ )

\begin{tabular}{|l|l|}
\hline Date & Time \\
\hline
\end{tabular}

Sampling Areas

Subplot radius $=24 \mathrm{ft}$ or $7.3 \mathrm{~m}$

Subplot area $=1,810 \mathrm{ft}^{2}$ or $168 \mathrm{~m}^{2}$

Microplot center $=12 \mathrm{ft} / 3.7 \mathrm{~m}$ at $90^{\circ}$ azimuth

Microplot radius $=6.8 \mathrm{ft}$ or $2.1 \mathrm{~m}$

Microplot area $=145 \mathrm{ft} 2$ or $13.5 \mathrm{~m} 2$

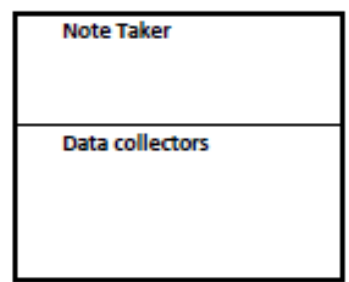

2) Timber Harvest Class

\begin{tabular}{|c|l|}
\hline \multicolumn{2}{|c|}{ Select dominant class $\rightarrow$} \\
\hline 1 & No evidence of cutting \\
\hline 2 & Some past logging evident \\
\hline 3 & Past logging obvious \\
\hline 4 & Recent harvesting \\
\hline 5 & Timber Stand Improvement \\
\hline 6 & Timber sale \\
\hline
\end{tabular}

\begin{tabular}{|c|c|c|c|c|c|}
\hline \multicolumn{7}{|c|}{ Non-Forest Land } \\
\hline \multicolumn{7}{|c|}{ Roads } & $\begin{array}{c}\text { Utility } \\
\text { Row }\end{array}$ & $\begin{array}{c}\text { Urban } \\
\text { Veg }\end{array}$ & Other \\
\hline & & & & & \\
\hline
\end{tabular}

3) Percent Canopy Cover (only for "Forest Land" as determined above)

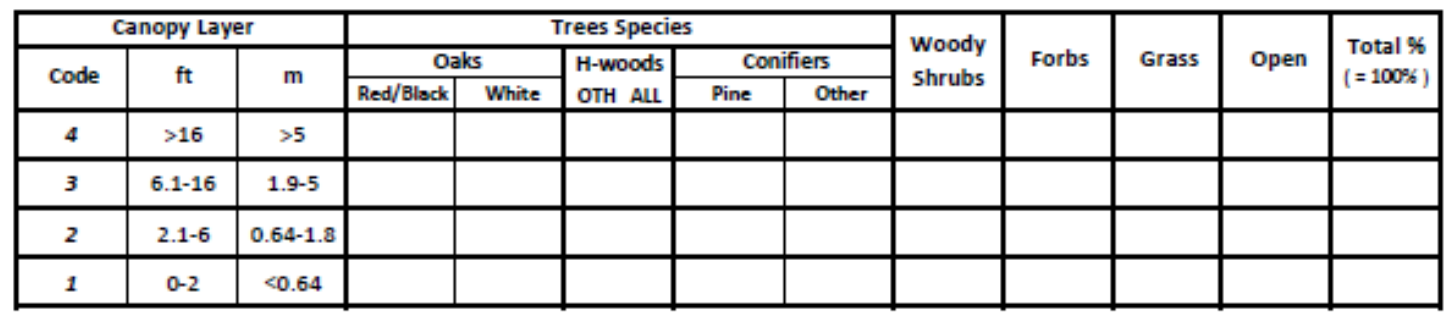

4) Litter, Duff, and A-horizon Depth

\begin{tabular}{|c|c|c|c|c|c|c|c|}
\hline \multirow{2}{*}{ Transect } & \multicolumn{4}{|c|}{ Subplot number/transect azimuth } & \multicolumn{3}{c|}{ Depth in mm } \\
\cline { 2 - 9 } & 1 & 2 & 3 & 4 & Litter & Duff & A-horizon \\
\hline 1 & 90 & 360 & 135 & 45 & & & \\
\hline 2 & 270 & 100 & 315 & 225 & & & \\
\hline 2-Dup & \multicolumn{3}{|c|}{ (1.5 m toward SP center from pit) } & & & \\
\hline
\end{tabular}

6) Pictures with GPS camera

\begin{tabular}{|c|c|c|}
\hline \multicolumn{2}{|c|}{ Record photograph number and time } \\
\hline Transect & Camera / pic no. & $\begin{array}{c}\text { Date and time of } \\
\text { picture }\end{array}$ \\
\hline 1 & & \\
\hline 2 & & \\
\hline
\end{tabular}

•Photograph direction: stand $2 \mathrm{~m}$ away from L-D-A pit and aiming toward SP center
5) Fire History Rating

\begin{tabular}{|c|l|}
\hline \multicolumn{2}{|l|}{ Select fire history rating- $->$} \\
\hline 1 & None \\
\hline 2 & Past low temp fire \\
\hline 3 & Recent low temp fire $(\mathrm{d} \mathrm{n})$ \\
\hline 4 & Canopy fire-saplings burned \\
\hline 5 & Canopy fire-Tree $>5^{\circ}$ burned \\
\hline
\end{tabular}

7) Site notes

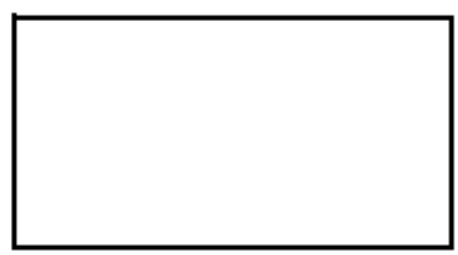




\section{Appendix E continued. Subplot Vegetation Form.}

Subplot Condition and Vegetation Field Form

Site

Subplot

OEWRI Fire Assessment Network (FAN-4SP)

Dec. 2015

8) Tree Stem Tally

Assess only trees/stumps $\times 0.13 \mathrm{~m}$ dia. within entire subplot at $7.3 \mathrm{~m}$ radius from center.

\begin{tabular}{|c|c|c|c|c|c|c|c|c|}
\hline Health & Stem & Tree & \multicolumn{2}{|c|}{ Size/DBH } & \multicolumn{2}{|c|}{ Location } & \multicolumn{2}{|c|}{ Bumed } \\
\cline { 5 - 8 } Lor D & Type & Species & Circ & Dia. & Zone $\left(^{\circ}\right)$ & Dist $(\mathrm{m})$ & Bark & Internal \\
\hline
\end{tabular}

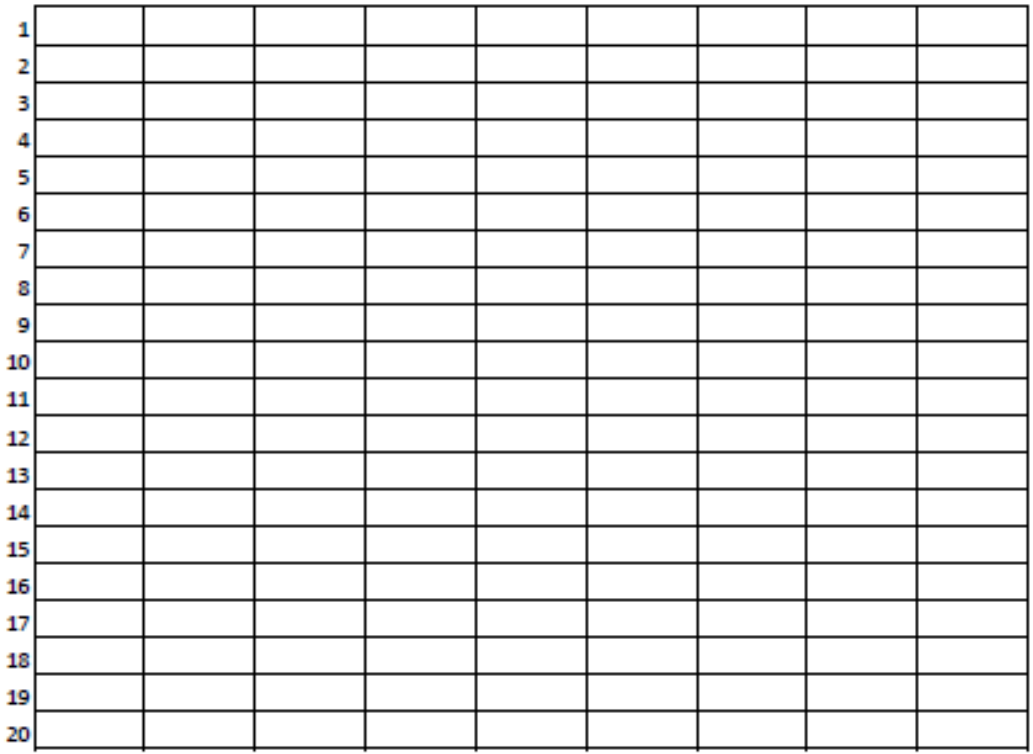

9) Sapling and Seedling Tally within the microplot, $3.7 \mathrm{~m}$ east with $2.1 \mathrm{~m}$ radius

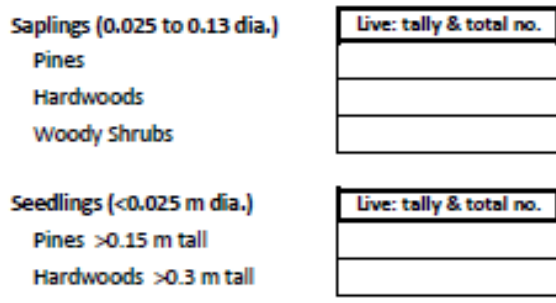

10 a) Coarse/Large Woody Debris Tally

Measureable piece: $>0.1 \mathrm{~m}$ dia $\&>1.5 \mathrm{~m}$ long or uprooted stumps $>1 \mathrm{~m}$ long)

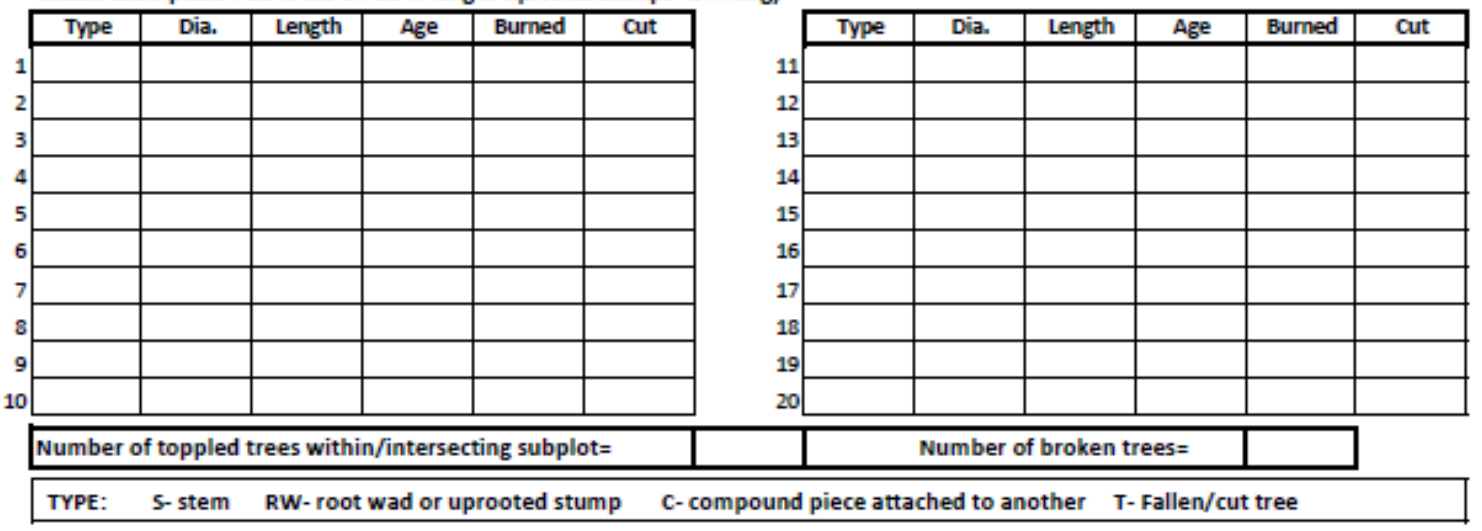




\section{Appendix F. Field Method error, Relative Percent Difference}

\begin{tabular}{ccccccccc}
\hline Site & $\begin{array}{c}\text { Tree } \\
\text { Count }\end{array}$ & $\begin{array}{c}\text { Pine } \\
\text { Count }\end{array}$ & $\begin{array}{c}\text { Basal } \\
\text { Area } \\
\left(\mathrm{m}^{2} / \mathrm{ha}\right)\end{array}$ & $\begin{array}{c}\text { Leaf litter } \\
\text { depth } \\
(\mathrm{mm})\end{array}$ & $\begin{array}{c}\text { Duff } \\
\text { depth } \\
(\mathrm{mm})\end{array}$ & $\begin{array}{c}\text { Sapling } \\
\text { density } \\
\left(\# / \mathrm{m}^{2}\right)\end{array}$ & $\begin{array}{c}\text { Seedling } \\
\text { density } \\
\left(\# / \mathrm{m}^{2}\right)\end{array}$ & $\begin{array}{c}\text { CWD } \\
\left(\mathrm{m}^{3} / \mathrm{ha}\right)\end{array}$ \\
\hline 1 & 7.69 & 15.38 & 12.53 & 17.32 & 16.21 & 45.62 & 67.98 & 86.63 \\
6 & 40.00 & 19.05 & 35.26 & 47.15 & 9.83 & 28.52 & 17.71 & 114.10 \\
18 & 6.06 & 6.90 & 8.41 & 24.65 & 24.24 & 36.29 & 94.16 & 109.38 \\
20 & 16.87 & 25.64 & 21.42 & 17.30 & 28.59 & 75.76 & 169.51 & 86.44 \\
21 & 5.41 & 0.00 & 24.39 & 11.78 & 44.70 & 103.82 & 178.79 & 43.97 \\
24 & 11.76 & 16.95 & 12.96 & 11.60 & 22.23 & 124.26 & 58.96 & 3.81 \\
26 & 12.50 & 66.67 & 7.55 & 33.09 & 57.13 & 110.98 & 40.00 & 15.65 \\
\hline
\end{tabular}




\section{Appendix G. Dry Mass of Litter and Duff.}

Appendix G-1. Dry Mass of Leaf Litter and Duff Methods.

Litter and duff samples were collected using a sampling frame with a diameter of $30 \mathrm{~cm}$ (FIA, 2011; Ottmar and Andreu, 2007). The frame was placed over the litter and duff layers. A knife was used to cut the litter and duff within the frame to remove the sample. Samples were processed at Missouri State University in the geomorphology laboratory. Samples were dried at $60^{\circ} \mathrm{C}$ for 24 to 48 hours, or until all moisture had been removed and then weighed. A $19.1 \mathrm{~mm}$ sieve was used to separate the litter and duff layers. Litter is the fraction of the sample $>19.1 \mathrm{~mm}$ and duff is the fraction $>19.1 \mathrm{~mm}$. Once separated the weight was recorded for litter and duff. Mass per area was calculated for litter and duff by taking the mass of each divided by the area of the sampling frame (Woodall and Monleon, 2008). This data provides information and estimates for forest floor fuel loadings (Woodall and Monleon, 2008). 
Appendix G-2. Dry Mass of Leaf Litter and Duff Results.

\begin{tabular}{cccc}
\hline Site & Stand type & Litter $\left(\mathrm{g} / \mathrm{m}^{2}\right)$ & Duff $\left(\mathrm{g} / \mathrm{m}^{2}\right)$ \\
\hline 1 & Oak & 131.46 & 591.55 \\
2 & Oak & 272.30 & 1061.03 \\
3 & Oak & 206.57 & 530.52 \\
4 & Oak & 98.59 & 586.85 \\
5 & Mixed & 211.27 & 460.09 \\
6 & Mixed & 220.66 & 624.41 \\
7 & Oak & 295.77 & 671.36 \\
8 & Oak & 187.79 & 920.19 \\
9 & Oak & 112.68 & 732.39 \\
10 & Oak & 187.79 & 413.15 \\
11 & Oak & 154.93 & 577.46 \\
12 & Pine & 521.13 & 1258.22 \\
13 & Oak & 51.64 & 234.74 \\
14 & Oak & 154.93 & 680.75 \\
15 & Oak & 300.47 & 511.74 \\
16 & Oak & 338.03 & 417.84 \\
17 & Oak & 413.15 & 553.99 \\
18 & Pine & 389.67 & 1014.08 \\
19 & Oak & 267.61 & 234.74 \\
20 & Oak & 417.84 & 502.35 \\
21 & Mixed & 403.76 & 854.46 \\
22 & Mixed & 586.85 & 910.80 \\
23 & Pine & 417.84 & 685.45 \\
24 & Pine & 431.92 & 793.43 \\
25 & Oak & 530.52 & 366.20 \\
26 & Mixed & 492.96 & 553.99 \\
27 & Oak & 333.33 & 469.48 \\
28 & Oak & 75.12 & 18.78 \\
29 & Oak & 234.74 & 370.89 \\
30 & Pine & 192.49 & 394.37 \\
\hline & & &
\end{tabular}


Appendix H. Nomograph to Determine Soil Erodibility (K-Factor) (Wade and Trimble, 2004).

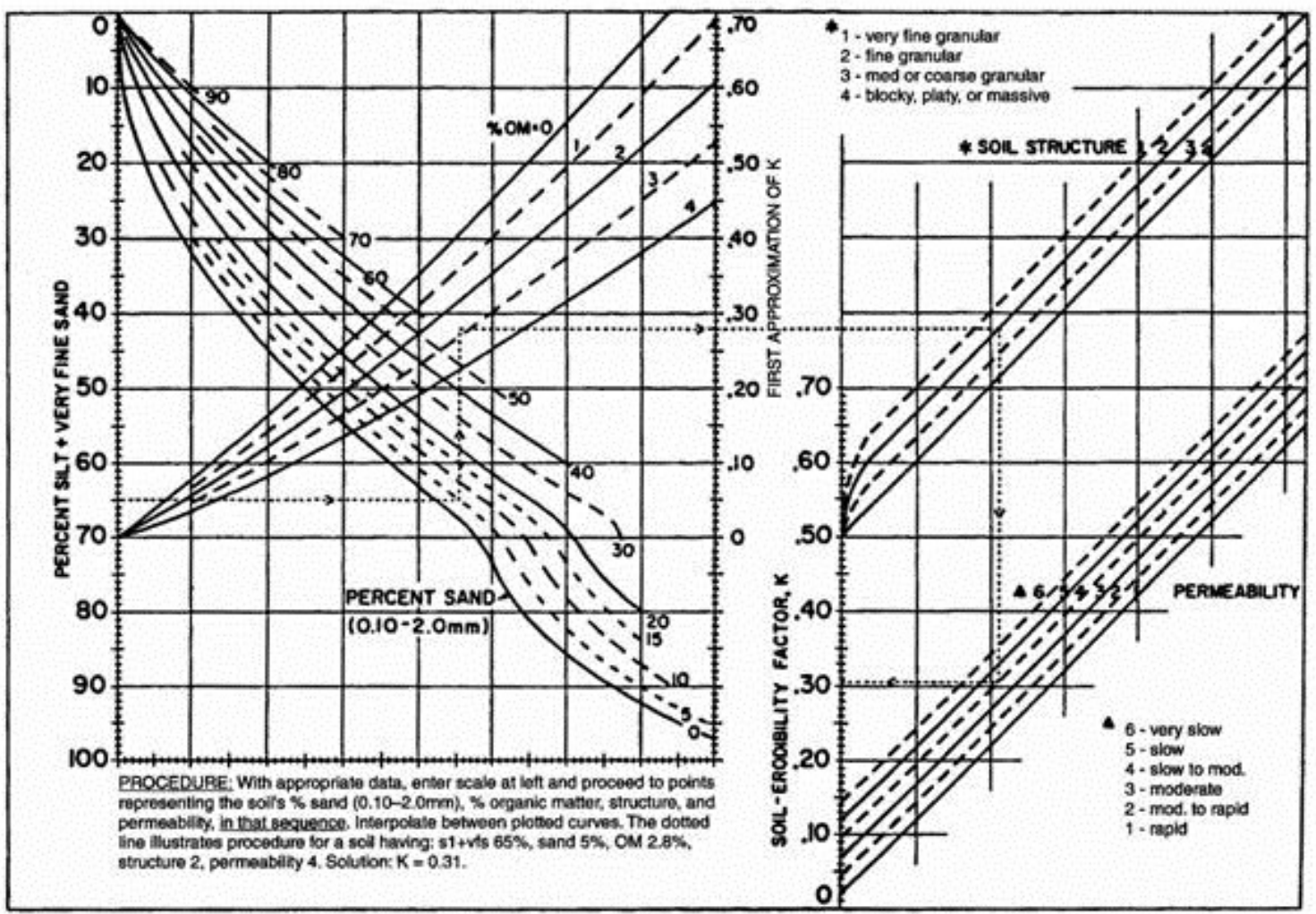


Appendix I. Soil Texture $<2 \mathrm{~mm}$ and Percent Rock Fragments $>2$ mm.

\begin{tabular}{|c|c|c|c|c|c|}
\hline \multicolumn{6}{|c|}{$0-5 \mathrm{~cm}$} \\
\hline Site & Stand type & $\%$ Sand & $\%$ Silt & $\%$ Clay & $\%$ Rock fragment $>2 \mathrm{~mm}$ \\
\hline 1 & Oak & 13.5 & 66.9 & 19.6 & 3.66 \\
\hline 2 & Oak & 26.0 & 56.3 & 17.6 & 19.02 \\
\hline 3 & Oak & 27.8 & 55.3 & 16.8 & 31.18 \\
\hline 4 & Oak & 32.7 & 52.7 & 14.7 & 25.94 \\
\hline 5 & Mixed & 8.6 & 68.4 & 23.0 & 9.18 \\
\hline 6 & Mixed & 15.2 & 64.7 & 20.2 & 8.90 \\
\hline 7 & Oak & 16.0 & 62.4 & 21.6 & 27.84 \\
\hline 8 & Oak & 11.0 & 65.0 & 24.1 & 31.64 \\
\hline 9 & Oak & 17.3 & 56.5 & 26.2 & 44.69 \\
\hline 10 & Oak & 12.2 & 67.7 & 20.1 & 16.62 \\
\hline 11 & Oak & 9.0 & 71.1 & 19.9 & 9.81 \\
\hline 12 & Pine & 23.0 & 59.7 & 17.3 & 5.15 \\
\hline 13 & Oak & 26.9 & 57.1 & 16.0 & 8.75 \\
\hline 14 & Oak & 21.8 & 60.3 & 17.9 & 25.74 \\
\hline 15 & Oak & 24.0 & 59.2 & 16.8 & 23.86 \\
\hline 16 & Oak & 16.8 & 65.4 & 17.8 & 3.98 \\
\hline 17 & Oak & 30.1 & 54.3 & 15.6 & 31.49 \\
\hline 18 & Pine & 17.1 & 64.0 & 18.9 & 40.53 \\
\hline 19 & Oak & 18.7 & 63.7 & 17.7 & 9.31 \\
\hline 20 & Oak & 16.4 & 65.9 & 17.7 & 5.57 \\
\hline 21 & Mixed & 11.6 & 68.8 & 19.6 & 2.95 \\
\hline 22 & Mixed & 20.0 & 62.9 & 17.2 & 14.39 \\
\hline 23 & Pine & 13.3 & 67.7 & 19.0 & 4.92 \\
\hline 24 & Pine & 16.3 & 65.1 & 18.7 & 33.12 \\
\hline 25 & Oak & 10.1 & 72.2 & 17.7 & 11.38 \\
\hline 26 & Mixed & 17.0 & 62.1 & 20.9 & 22.21 \\
\hline 27 & Oak & 18.1 & 62.1 & 19.8 & 25.10 \\
\hline 28 & Oak & 16.8 & 62.5 & 20.7 & 22.46 \\
\hline 29 & Oak & 9.5 & 68.8 & 21.5 & 7.95 \\
\hline 30 & Pine & 30.6 & 52.8 & 16.6 & 23.98 \\
\hline
\end{tabular}


Appendix I continued. Soil Texture $<\mathbf{2} \mathbf{~ m m}$ and Percent Rock Fragments $>\mathbf{2} \mathbf{~ m m}$.

\begin{tabular}{|c|c|c|c|c|c|}
\hline \multicolumn{6}{|c|}{$5-10 \mathrm{~cm}$} \\
\hline Site & Stand type & $\%$ Sand & $\%$ Silt & $\%$ Clay & $\%$ Rock fragment $>2 \mathrm{~mm}$ \\
\hline 1 & Oak & 13.0 & 65.0 & 22.0 & 3.56 \\
\hline 2 & Oak & 26.5 & 55.3 & 18.2 & 20.72 \\
\hline 3 & Oak & 27.3 & 54.9 & 17.9 & 31.13 \\
\hline 4 & Oak & 31.9 & 52.7 & 15.5 & 18.71 \\
\hline 5 & Mixed & 5.9 & 69.5 & 24.5 & 7.88 \\
\hline 6 & Mixed & 13.5 & 66.0 & 20.5 & 6.14 \\
\hline 7 & Oak & 16.6 & 60.4 & 23.0 & 17.41 \\
\hline 8 & Oak & 10.0 & 64.9 & 25.1 & 18.64 \\
\hline 9 & Oak & 10.1 & 58.2 & 31.7 & 25.00 \\
\hline 10 & Oak & 7.9 & 70.5 & 21.6 & 18.13 \\
\hline 11 & Oak & 5.6 & 72.9 & 21.4 & 9.61 \\
\hline 12 & Pine & 19.3 & 61.7 & 19.0 & 5.95 \\
\hline 13 & Oak & 27.9 & 55.6 & 16.5 & 10.73 \\
\hline 14 & Oak & 18.8 & 61.9 & 19.4 & 24.67 \\
\hline 15 & Oak & 17.7 & 63.0 & 19.3 & 21.90 \\
\hline 16 & Oak & 13.3 & 67.0 & 19.7 & 5.50 \\
\hline 17 & Oak & 26.9 & 55.8 & 17.3 & 26.66 \\
\hline 18 & Pine & 14.2 & 65.3 & 20.5 & 20.93 \\
\hline 19 & Oak & 14.8 & 65.6 & 19.6 & 22.82 \\
\hline 20 & Oak & 14.7 & 66.4 & 18.9 & 10.51 \\
\hline 21 & Mixed & 10.3 & 68.5 & 21.2 & 6.40 \\
\hline 22 & Mixed & 16.7 & 65.1 & 18.1 & 7.66 \\
\hline 23 & Pine & 11.2 & 68.9 & 19.9 & 5.51 \\
\hline 24 & Pine & 16.7 & 64.3 & 18.9 & 29.69 \\
\hline 25 & Oak & 3.6 & 76.8 & 19.6 & 12.25 \\
\hline 26 & Mixed & 13.2 & 64.5 & 22.3 & 16.21 \\
\hline 27 & Oak & 15.4 & 63.1 & 21.5 & 34.61 \\
\hline 28 & Oak & 13.0 & 65.5 & 21.5 & 30.76 \\
\hline 29 & Oak & 6.4 & 70.5 & 23.0 & 17.63 \\
\hline 30 & Pine & 22.7 & 57.7 & 19.5 & 36.76 \\
\hline
\end{tabular}

